\title{
Cooperative Research and Development of Primary Surface Recuperator for Advanced Microturbine Systems
}

Final Technical Progress Report No. 26

Reporting Period: October 1, 2000 to October 31, 2006

Submitted to:

Douglas Gyorke

U.S. Department of Energy

National Energy Technical Laboratory

626 Cochrans Mill Road

PO Box 10940

Pittsburgh, PA 15236-0940

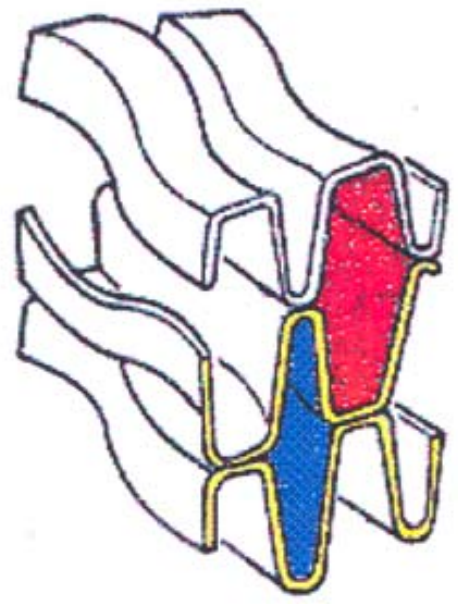

Issued: January 31,2007

Prepared by:

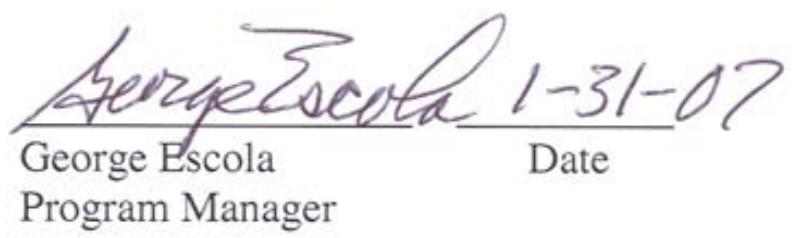

Approved by:

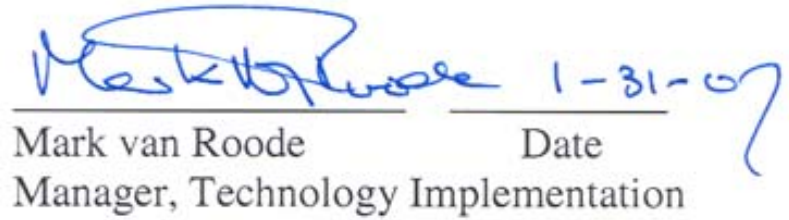

\section{Solar Turbines Incorporated}

A Caterpillar Company

2200 Pacific Highway

San Diego, California 92186

Customer Ref:

DE-FC26-00CH11062 


\section{ACKNOWLEDGEMENTS}

The input and comments of Oak Ridge National Laboratory, J.H. Benedict Company, Allegheny Ludlum Corporation, and Arthur Metcalfe and Associate as key team members of the Program Team are hereby gratefully acknowledged.

\section{DISCLAIMER}

This report was prepared as an account of work sponsored by an agency of the United States Government. Neither the United States Government nor any agency thereof, nor any of their employees, makes any warranty (expressed or implied), or assumes any legal liability or responsibility for the accuracy, completeness, or usefulness of any information, apparatus, product, or process disclosed, or represents that its use would not infringe privately owned rights. Reference herein to any specific commercial product, process, or service by trade name, trademark, manufacturer, or otherwise does not necessarily constitute or imply its endorsement, recommendation, or favoring by the United States Government or any agency thereof 


\section{TABLE OF CONTENTS}

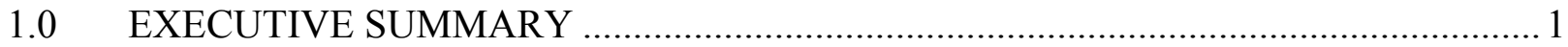

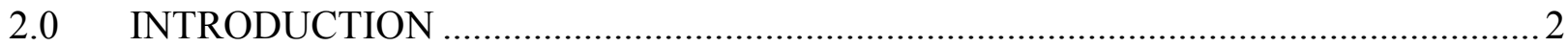

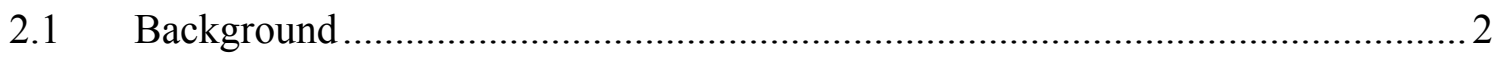

2.2 Benefits to Microturbines from Solar's Recuperator Material Development Program ..................................................................................... 4

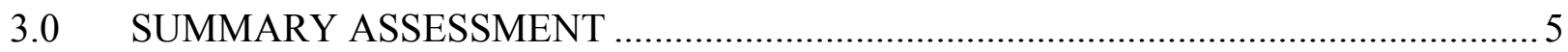

3.1 Overall Assessment of Performance.............................................................. 5

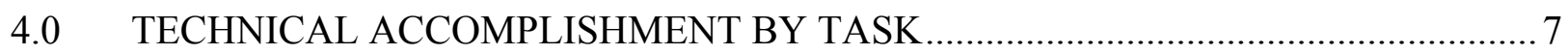

4.0.1 Task 0.0 Project Initiation..................................................................

4.0.2 Task 1.1 Topical Report...................................................................

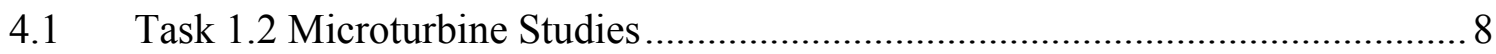

4.2 Task 1.3 Recuperator Alloy Development......................................................... 8

4.2.1 Task 1.3.1 Coated Type 347 SS Foil ..................................................... 9

4.2.2 Task 1.3.2 Creep Resistant Type 347 SS Foil ....................................... 12

4.2.3 Task 1.3.3 Advanced Austenitic (AA) Foil ............................................... 16

4.2.4 Task 1.3.4 Coated Advanced Austenitic (AA) Foil..................................23

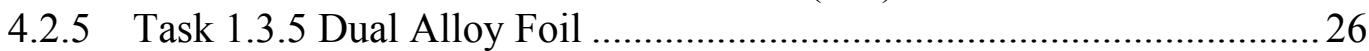

4.2.6 Task 1.3.6 Super-Alloy Foil...............................................................29

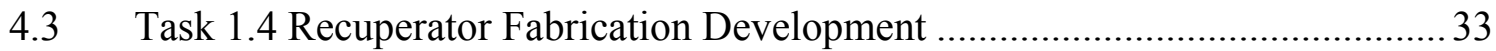

4.3.1 Task 1.4.1 Primary Sheet Folded Stock Monitoring...................................33

4.3.2 Task 1.4.2 Improving Primary Sheet Parameters ........................................ 34

4.3.3 Task 1.4.3 Pressure Drop Reduction.......................................................... 34

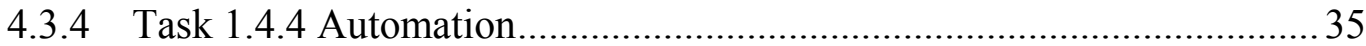

4.3.4.1 Task 1.4.4.1 Automation - Vision Welding ..................................35

4.3.4.2 Task 1.4.4.2 Automation - Robot Duct Welding ..........................36

4.3.4.3 Task 1.4.4.3 Automation - Laser Welding .................................... 37

4.3.5 Task 1.4.5 Fin Folder Design of Experiments ............................................37 
4.4 Task 1.5 Cost Evaluation ..................................................................... 42

4.5 Task 1.6 Recuperator Endurance Testing .................................................... 43

4.6 Task 1.7 Microturbine PSR Concept Design ............................................. 46

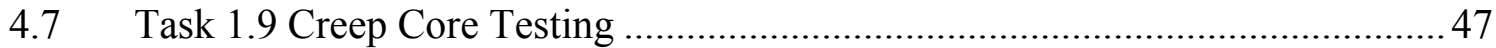

4.8 Task 2.0 Microturbine Recuperator Development.......................................... 51

5.0 Task 1.8 PROGRAM MANAGEMENT .......................................................... 51

$5.1 \quad$ Program Management Activities .......................................................... 51

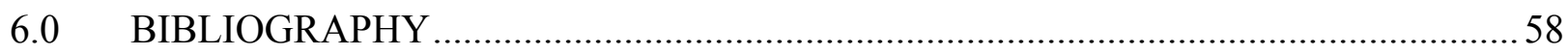




\section{FIGURES}

Figure 2.1-1 Recuperators Manufactured by Solar Turbines Incorporated .............................3

Figure 3.1-1 The Microturbine Recuperator Team......................................................6

Figure 4.2.1-1 Oxidation Test Fixture for Humidified Air Exposure Testing.........................10

Figure 4.2.1-2 Total Weight Gain for TPG-coated Type 347 SS ..........................................10

Figure 4.2.1-3 Total Weight Gain for Type 347 SS Foil Coated with Sermatech

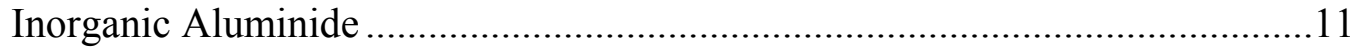

Figure 4.2.1-4 Total Weight Gain for Solaramic S5-8A ${ }^{\text {TM }}$ Coated Type 347 SS Foil as Coated (purple) and Pre-oxidized (green) .....................................................11

Figure 4.2.1-5 Metallographic Cross-section of a Solaramic S5-8A $\mathrm{A}^{\mathrm{TM}}$ Coated Type 347 SS Foil after Exposure ................................................................12

Figure 4.2.2-1 Comparative Weight Gains of Type 347 SS Foil .........................................14

Figure 4.2.2-2 Metallurgical Cross-sections through a Type 347 SS Specimen that was Exposed for 1,000 hours at $1300^{\circ} \mathrm{F}$ in $10 \%$ Humidified air .................14

Figure 4.2.2-3 Type 347 SS Foil Creep Curves of Laboratory Heats ...................................15

Figure 4.2.2-4 Comparative Creep Properties of Standard Type 347 SS Foil and Heat HFA ...15

Figure 4.2.3-1 Comparative Weight Gain of Type 347 and AA Foil after 1,000 Hours of Exposure .18

Figure 4.2.3-2 Weight Gain and Fitted Curves for AA Foil Exposed to $1300^{\circ} \mathrm{F}, 1400^{\circ} \mathrm{F}$, and $1500^{\circ} \mathrm{F}$

Figure 4.2.3-3 SEM Photomicrograph of Cross-section Through an AA Specimen that was Exposed for 10,000 Hours at $1300^{\circ} \mathrm{F}$ in $10 \%$ Humidified Air

Figure 4.2.3-4 Comparative 1\% Creep Larson-Miller Curve for Type 347 SS and AA Foil ....20

Figure 4.2.3-5 Sub-size Air Cell Manufactured from AA Foil Material.................................21

Figure 4.2.3-6 Ultimate Tensile Strength of AA Sheet Material..........................................22

Figure 4.2.3-7 Yield Strength of AA Sheet Material........................................................22

Figure 4.2.3-8 Percent Elongation of AA Sheet Material ....................................................22 
Figure 4.2.4-1 Total Weight Gain for AS\&M Two-phase Coated AA Foil After 1,000 Hours of Exposure

Figure 4.2.4-2 Total Weight Gain for Inorganic Aluminide (Sermatel 565) Coated AA Foil After 1,000 hours of Exposure.

Figure 4.2.4-3 Average Weight-gain for Solaramic S5-8A ${ }^{\text {TM }}$ Coated AA Foil After 500 Hours of Exposure

Figure 4.2.4-4 AA Foil with Solaramic S5-8A TM Coating Before (top) and After 500 Hours at $1400^{\circ} \mathrm{F}$ in $10 \%$ Humidified Air (bottom) ..............................................25

Figure 4.2.4-5 Weight Gained by Coated and Uncoated AA Foil........................................26

Figure 4.2.5-1 Photomicrograph of Cross-section Through Fabricated Dual Clad Assemblies Showing Alloy 800 (left) and Type 310 SS Foil (right) Successfully Bonded to Type 347 SS Core Material

Figure 4.2.5-2 Weight Gain of the Potential Cladding Materials Compared with AA Foil After 2,000 Hours of Exposure at $1400^{\circ} \mathrm{F}$ in $7 \%$ Humid Air .28

Figure 4.2.5-3 SEM Photomicrograph of the Surface Region on a Type 347 SS Clad with Type $310 \mathrm{SS}$ that was Exposed at $1300^{\circ} \mathrm{F}$ in $7 \%$ Humidified Air for 5,000 Hours .28

Figure 4.2.6-1 Weight Gain of Alloy 625, Alloy X and AA Foil Exposed for 10,000 Hours at $1400^{\circ} \mathrm{F}$ in $7 \%$ Humidified Air. .30

Figure 4.2.6-2 SEM Photomicrograph of Cross-section through an Alloy 625 Specimen that was Exposed for 15,865 Hours at $1500^{\circ} \mathrm{F}$ in $7 \%$ Humidified Air 31

Figure 4.2.6-3 Residual Chromium in Alloy 625 as a Function of Depth after 8,000 Hours (7\% Humidified Air) and 10,000 Hours (ambient) at $1400^{\circ} \mathrm{F}$

Figure 4.2.6-4 Experimentally Measured and Experimentally Calculated Model for Alloy 625 Exposed at $1400^{\circ} \mathrm{F}$ and $1500^{\circ} \mathrm{F}$ in $7 \%$ Humidified Air.

Figure 4.2.6-5 Comparative 1\% Creep Larson-Miller Curve for Alloy 625,

Type 347 SS and AA Foil. .33

Figure 4.4.5-1 Fin Folder, Model 900 at JH Benedict............................................................39

Figure 4.5-1 Alloy 625 Panel with Alloy 625 and AA Coupons that were Exposed to Mercury 50 Exhaust Gas 
Figure 4.5-2 Auger Depth Profiles of AA Coupons Exposed for 7,650 Hours in Mercury 50 Recuperator

Figure 4.5-3 Metallurgical Section through an Alloy 625 Coupon after 7,650 Hours of Exposure in a Mercury 50 Recuperator.

Figure 4.7-1 Creep Core Assembly Schematic..........................................................48

Figure 4.7-2 Creep Core Test Assembly ......................................................................4 48

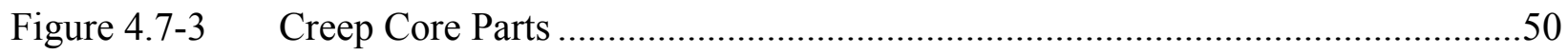

Figure 5.1-1 Funding and Spending Over the Life of the Contract.....................................55

Figure 5.1-2 Program Schedule ..................................................................................56

\section{TABLES}

Table 4.2.3-1 Composition of AA Foil Material Heat .......................................................17

Table 4.2.5-1 Composition of Potential Clad Foils .........................................................2

Table 4.2.6-1 Composition of Candidate Superalloy Foils ................................................29

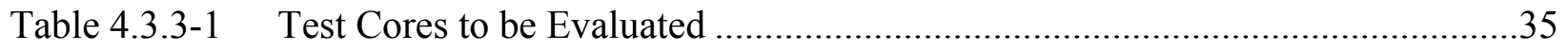

Table 4.5-1 Test Cell Exposure Information.............................................................45

Table 4.7-1 Creep Core Conditions............................................................................49

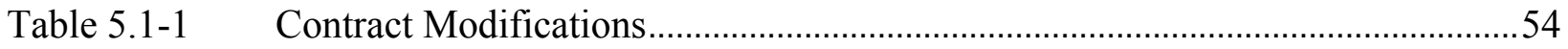




\subsection{EXECUTIVE SUMMARY}

A higher temperature recuperator-operating limit is essential to meeting the performance goal for microturbines. The Cooperative Research and Development of Primary Surface Recuperator for Advanced Microturbine Systems Program, awarded to Solar Turbines Incorporated (Solar) in September 2000, was directed towards meeting the future requirements of advanced gas turbine systems by:

$>$ The development of advanced alloys that will allow recuperator inlet exhaust gas temperatures to increase without significant cost increase.

$>$ Further characterization of the creep and oxidation (dry and humid air) properties of nickel alloy foils (less than $0.13 \mathrm{~mm}$ thick) to allow the economical use of these materials.

$>$ Increasing the use of advanced automated systems to reduce the cost of manufacturing recuperators.

The program was originally structured into two tasks with the first task focused on material development and the development of advanced manufacturing processes and the second task focused on working with microturbine companies to develop advanced recuperators for microturbine systems.

Solar Turbines Incorporated (Solar) had supplied recuperators to most major microturbine original equipment manufacturers (OEMs) and had shipped over 2,300 recuperators for microturbine applications. However, the forecasted demand for micro-turbine systems decreased dramatically and in 2001 Solar made a strategic business decision to discontinue recuperator fabrication for the microturbine OEMs. After reaching mutual agreement, DOE and Solar redirected and restructured the program to better fit the available funding and program objectives. The redirected program concentrated on the development of a new, economical recuperator material, an Advanced Austenitic (AA) that would allow operation at higher temperatures. The AA has oxidation and creep properties significantly better than Type 347 SS and oxidation properties similar to that of Alloy 625. In addition, AA has creep properties similar to Alloy 625 at lower stress levels and was forecasted to cost significantly less than Alloy 625. Tasks involving direct work with microturbine companies were dropped as Solar made a business decision to license the manufacture of microturbine recuperators to microturbine OEM's. To further decrease funding requirements, some manufacturing technologies intended to reduce total recuperator cost were continued under Solar funding while others were delayed until funding became available. Laboratory tests to verify material capabilities remained part of the work scope along with the build of a full-scale, Mercury 50 recuperator for final material capability verification. Testing of the full-scale recuperator was to be performed as part of other Solar-funded programs. The initial build and after-test evaluation of the full-scale recuperator was retained within the program scope of work. The new AA material was to be made available to all, including microturbine companies for evaluation and commercial use within microturbine recuperators.

A large portion of the development of the AA was conducted by Allegheny Ludlum (A-L) and, due to the very favorable results, A-L elected to commercialize the new recuperator material. Solar negotiated an intellectual property agreement with A-L, based on the approved Government patent waiver, and commercialization plans include the sale of this material to all who wish to purchase it. Oak Ridge National Laboratories (ORNL) is also facilitating the 
introduction of the AA (now commercially named AL20-25+ $\mathrm{Nb}^{\mathrm{TM}}$ ) to microturbine OEMs for incorporation into their recuperators.

A collaborative effort with ORNL to help calibrate the creep model for thin foil materials was launched in 2003. The current creep model was developed for sheet and plate, but predictions from this model do not agree with observed creep in thin-foil recuperators operated in a turbine exhaust environment. Data for the creep model was generated from long term high temperature furnace experiments on Type $347 \mathrm{SS}$, the baseline recuperator alloy used by most of the microturbine OEMs, AA and Alloy 625, a high performance alloy used for high temperature metallic recuperators.

An additional effort to improve the robustness of the fin folding process was started in early 2004. This effort was designed to systematically analyze the fin folding process in a way that allows reduction in process variability and improves the capability to produce primary sheet material that meets all drawing requirements, thereby improving recuperator performance and reducing the assembly time throughout the recuperator build cycle.

Solar's development work will have a near-term benefit for microturbine companies by providing them with an affordable recuperator material that will enable them to operate at higher exhaust temperatures and achieve higher efficiencies. Improved manufacturing processes will reduce their total cost of recuperator production. This will enable them to uprate their products, increase end user satisfaction, resulting in higher sales volume, and achieving faster market penetration.

\subsection{INTRODUCTION}

Recuperators have been identified as key components of advanced gas turbines systems that achieve a measure of improvement in operating efficiency and lead the field in achieving very low emissions. Every gas turbine manufacturer that is studying, developing, or commercializing advanced recuperated gas turbine cycles requests that recuperators operate at higher temperature without a reduction in design life and must cost less.

The Solar Cooperative Research and Development of Primary Surface Recuperator for Advanced Microturbine Systems Program is directed towards meeting the future requirements of advanced gas turbine systems by the following:

$>$ The development of advanced alloys that will allow recuperator inlet exhaust gas temperatures to increase without significant cost increase.

$>$ Further characterization of the creep and oxidation (dry and humid air) properties of nickel alloy foils (less than $0.13 \mathrm{~mm}$ thick) to allow the economical use of these materials.

$>$ Increasing the use of advanced robotic systems and advanced in-process statistical measurement systems.

\subsection{Background}

In September 2000, Solar was awarded Cooperative Agreement No. DE-FC02-00CH11062, Cooperative Research and Development of Primary Surface Recuperator for Advanced 
Microturbine Systems. (The contract number was subsequently changed to DE-FC2600CH11062.)

The program was originally structured into two tasks requiring 42 months. The first task was focused on the development, characterization, and verification of advanced high-temperature alloys and the development and verification of advanced manufacturing process technologies. The second task was focused on working with microturbine companies in the design and testing of recuperators using the new alloy and manufacturing technologies in their advanced microturbine systems.

Solar Turbines Incorporated (Solar) had supplied recuperators to most major microturbine original equipment manufacturers (OEMs), including Capstone, Elliott Energy Systems, Honeywell Power Systems, TURBEC, and others. (See Fig. 2.1-1.) Solar has shipped over 2,300 recuperators for microturbine applications. However, the forecast demand for microturbine systems decreased dramatically and by 2001, two companies announced that they would no longer be in the microturbine business. Solar made a strategic business decision to discontinue recuperator fabrication for the microturbine OEMs. On the other hand, the Solar Mercury $^{\mathrm{TM}} 50$ neared market introduction. The Mercury 50 engine has a high temperature recuperator as a core assembly. The experience gained with recuperator materials and manufacturing development for the Mercury 50 would be very valuable for the microturbine OEMs in their efforts to develop high performance recuperators for their advanced microturbines. These factors together with the funding profile for fiscal year 2001 (FY01) and FY02, which was less than required for the original program plan, led DOE and Solar to redirect and restructure the program to better fit the available funding and program objectives.

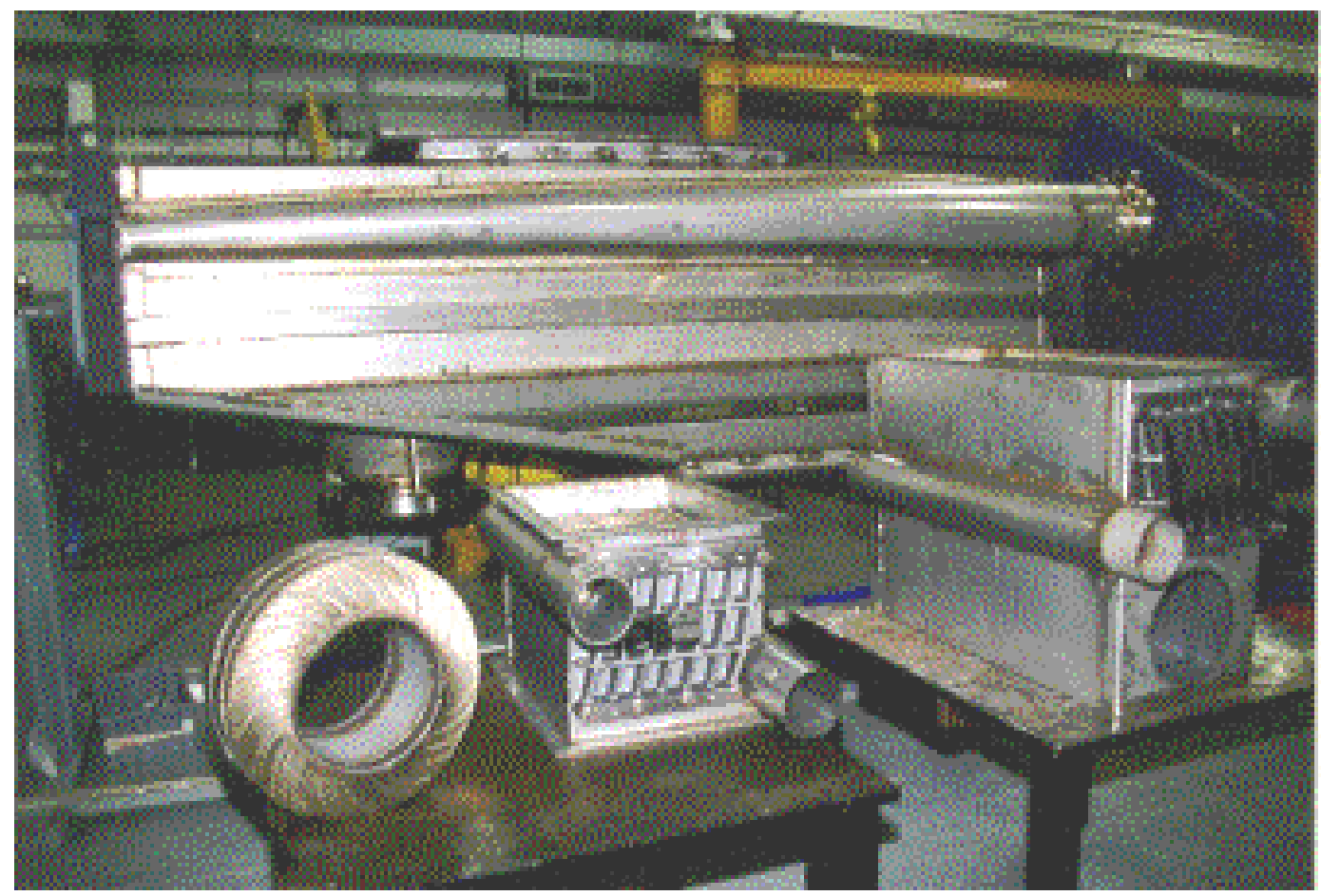

Figure 2.1-1. Recuperators Manufactured by Solar Turbines Incorporated 
The redirected program concentrated on the development of a new, economical recuperator material, an Advanced Austenitic (AA) that would allow operation at higher temperatures. The AA has oxidation and creep properties significantly better than Type 347 SS and oxidation properties similar to that of Alloy 625. In addition, AA has creep properties similar to Alloy 625 at lower stress levels and was forecasted to cost significantly less than Alloy 625. Tasks involving direct work with microturbine companies were dropped as Solar made a business decision to license the manufacture of microturbine recuperators to microturbine OEM's. To further decrease funding requirements, some manufacturing technologies intended to reduce total recuperator cost were continued under Solar funding while others were delayed until funding became available. Laboratory tests to verify material capabilities remained part of the work scope along with the build of a full-scale, Mercury 50 recuperator for final material capability verification. Testing of the full-scale recuperator was to be performed as part of other Solarfunded programs. The initial build and after-test evaluation of the full-scale recuperator was retained within the program scope of work. The new AA material was to be made available to all, including microturbine companies for evaluation and commercial use within microturbine recuperators.

A large portion of the development of the AA was conducted by Allegheny Ludlum (A-L) and, due to the very favorable results, A-L elected to commercialize the new recuperator material. Solar negotiated an intellectual property agreement with A-L based on the approved Government patent waiver. Commercialization plans include the sale of this material to all who wish to purchase it. Oak Ridge National Laboratories (ORNL) is also facilitating the introduction of the AA (now commercially named AL20-25+ $\mathrm{Nb}^{\mathrm{TM}}$ ) to microturbine OEMs for incorporation into their recuperators.

A collaborative effort with ORNL to help calibrate the creep model for thin foil materials was launched in 2003. The current creep model was developed for sheet and plate, but predictions from this model do not agree with observed creep in thin-foil recuperators operated in a turbine exhaust environment. Data for the creep model was generated from long term high temperature furnace experiments on Type $347 \mathrm{SS}$, the baseline recuperator alloy used by most of the microturbine OEMs, AA and Alloy 625, a high performance alloy used for high temperature metallic recuperators.

An additional effort to improve the robustness of the fin folding process was started in early 2004. This effort was designed to systematically analyze the fin folding process in a way that allows reduction in process variability and improves the capability to produce primary sheet material that meets all drawing requirements, thereby improving recuperator performance and reducing the assembly time throughout the recuperator build cycle.

\subsection{Benefits to Microturbines from Solar's Recuperator Material Development Program}

The primary benefits of this project are (1) development of a new, economical advanced austenitic recuperator material (with improved oxidation and creep properties) available to the microturbine OEMs and for other applications, (2) improvements to primary surface recuperator manufacturing processes, and (3) a database for nickel-based alloy foil.

Specific benefits of the development of the new advanced austenitic recuperator material and other program developments include: 
- Operation at higher temperatures and efficiencies over the design life of current recuperators.

- Operation at higher turbine inlet temperatures and efficiencies.

- Reduced total recuperator cost because of lower cost of AA compared to Type 347 SS.

- Reduced total recuperator cost by use of improved manufacturing technologies.

- An extensive materials database from laboratory and rig tests for Type 347 SS, AA, and Alloy 625.

- Building and testing a full-size recuperator for 2000 hours (minimum) for process and material capability verification.

- Evaluation of the selected recuperator materials after engine testing to increase the materials database.

- New alloys and materials data available to microturbine and all other companies.

Other Considerations:

- The AA developed under the program is likely to find commercialization applications far beyond recuperators.

- The program adds to technical database for materials.

- Solar's Mercury 50 program is likely to go forward to commercial production with more robust recuperator material and processes.

Solar's development work will have a near-term benefit for microturbine companies by providing them with an affordable recuperator material that will enable them to operate at higher exhaust temperatures and achieve higher efficiencies. Improved manufacturing processes will reduce their total cost of recuperator production. This will enable them to uprate their products, increase end user satisfaction, resulting in higher sales volume, and achieving faster market penetration.

\subsection{SUMMARY ASSESSMENT}

\subsection{Overall Assessment of Performance}

This Program was directed towards meeting the future requirements of advanced gas turbine systems by the following:

$>$ The development of an advanced stainless steel alloy that will allow recuperator inlet exhaust gas temperatures to increase.

Over the 72 months of the extended program, the team (see Fig. 3.1-1) accomplished the development and commercialization of an advanced austenitic foil material. This material is now commercially available from Allegheny Ludlum as $\mathrm{AL} 20-25+\mathrm{Nb}^{T M}$. Oxidation and creep strength properties of this material have proven superior to Type 347 SS, historically the standard recuperator material. Oxidation and creep-strength testing on $\mathrm{AL} 20-25+\mathrm{Nb}^{\mathrm{TM}}$ was carried out for 15,000 hours at $1,300^{\circ} \mathrm{F}$ and $1,400^{\circ} \mathrm{F}$ in humid air simulating the turbine exhaust gases. These samples failed to reach breakaway and an accelerated test at $1,500^{\circ} \mathrm{F}$ was started. Breakaway was finally achieved in just over 8,000 hours. The cost premium of AL $20-25+\mathrm{Nb}^{T M}$ when compared to Type $347 \mathrm{SS}$ is about 1.4 to 1.8 times higher which is significantly less when compared to nickel-based alloys, such as Alloy 625, at 3 to 6 times higher. Details of the development of the advanced stainless steel alloy foil are contained in Task 1.3.3 below. 
Additional work toward improving existing materials for use in recuperators is detailed in Tasks 1.3.1, 1.3.2, 1.3.4, and 1.3.5. Field-testing and evaluation of selected recuperator materials in Mercury 50 exhaust was conducted in Task 1.6.

Further characterization of the creep and oxidation (dry and humid air) properties of nickel alloy foils (less than $0.13 \mathrm{~mm}$ thick) to allow the economical use of these materials.

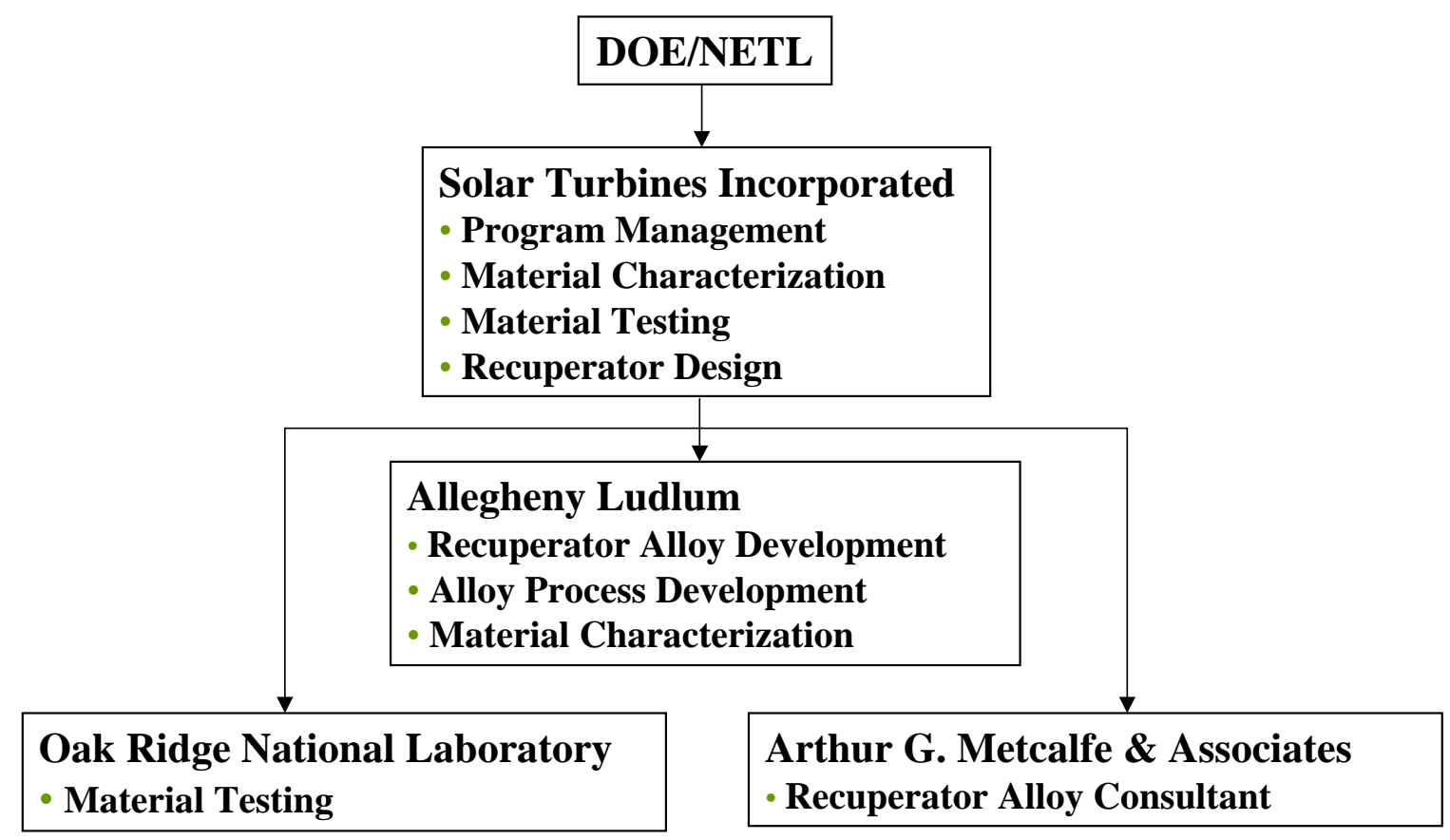

Figure 3.1-1. The Microturbine Recuperator Team

Extensive data on the characteristics of nickel alloys was collected over the period of performance of this program. Oxidation and creep-strength testing on Alloy 625 and Alloy X was carried out for 15,000 hours at $1300^{\circ} \mathrm{F}$ and $1400^{\circ} \mathrm{F}$ in humid air simulating the turbine exhaust gases. These samples failed to reach breakaway and an accelerated test at $1500^{\circ} \mathrm{F}$ was started. Breakaway was finally achieved in just over 15,850 hours. Details of the characterization of the creep and oxidation (dry and humid air) properties of nickel alloy foils are contained in Task 1.3.6 below.

Additionally, creep-core testing was performed at various temperatures for 7,500 hours. Details of these tests and the results are contained in Section 4.7, Task 1.9 below.

Increasing the use of advanced robotic systems and advanced in-process statistical measurement systems. 
Effort here was focused in five areas:

- 1.4.1 Primary Sheet Monitoring

- 1.4.2 Improved Primary Sheet Parameters

- 1.4.3 Pressure Drop Reduction

- 1.4.4 Automation Development

- Vision Welding

- Robotic Duct Welding

- Laser Welding

- 1.4.5 Fin Folding Process Optimization

Details of these efforts and the results are contained in Section 4.2, Task 1.4 below.

\subsection{TECHNICAL ACCOMPLISHMENT BY TASK}

Statement of work: WBS 1.0 Concept Development - Work under this task will define the development work to uprate the Solar primary surface recuperator (PSR) for the microturbine program goals of thermal efficiency, output power, emissions, time between overhaul, and service life of the MT-OEMs own programs.

\subsubsection{Task 0.0 Project Initiation}

A coordination kick-off meeting was held October 10, 2000 in St. Louis with the subcontractors attending the ASM meeting. In attendance were representatives from A-L, ORNL, and Solar. A general overview of the program was discussed with near term action items identified.

Contract terms with ORNL, A-L, and Arthur Metcalfe and Associates (AMA) were finalized and the applicable purchase orders initiated. Both AMA and A-L accepted the terms of the resulting purchase orders. However, the subcontract with ORNL was not signed because ORNL refused the terms of Solar's purchase order and flow-down terms of the DOE prime contract. Instead, they insisted on acceptance of their "Work-for-other Agreement" which placed their terms above all others. Discussion continued for several months looking for common ground with ORNL. In the end, ORNL was unable to accept the terms of Solar's purchase order and subcontract negotiations were suspended. Solar received quotes from alternate sources and placed purchase orders to the necessary work to complete this program.

General agreement on the intellectual property agreement between Solar and A-L was established early in 2001. However, the legal details took several face-to-face meetings and months of negotiation. The final Intellectual Property Agreement was completed on February 6, 2004. Alloy development work continued throughout this period as the intellectual property agreement affected only the commercialization of the developed alloy.

\subsubsection{Task 1.1 Topical Report}

Statement of Work: WBS 1.1 Topical Report (Subtask A) - To satisfy the requirements of subtask A, a Topical Report will be submitted to DOE within 90 days of award of the Cooperative Agreement. Solar will identify and quantify the potential technical markets for the microturbine 
recuperators to be developed under this program. The role of the developed recuperators in meeting the microturbine OEMs commercial and program goals will be specified. Rationale will be provided that supports such projections. Any barriers for the technical market resulting from limitations of current recuperator performance and durability will be identified.

Work done under WBS 1.1 to organize and get the program work started was originally budgeted under WBS 1.8. It was completed in fiscal year 2001. The Topical Report, Subtask A was completed in 2004 under WBS 1.5, Cost Evaluation, but was charged under WBS 1.8, Program Management. The report is titled "Primary Surface Recuperator for Advanced Microturbine Systems Development Program Task 1.5 Recuperator Cost Evaluation Topical Report.”

\subsection{TASK 1.2 MiCROTURBINE STUdIES}

Statement of work: WBS 1.2 Microturbine Studies - All Task 1 activities of the microturbine manufacturers on the Solar led team will be incorporated under this subtask. The three microturbine manufacturers participating on the Solar microturbine recuperator development team, Capstone, Elliott Energy Systems (EES), and United Technologies Research Center (UTRC) will conduct cycle, concept engine and package design, and cost studies to guide the PSR development. The selected baseline will be an existing microturbine system or other engine configuration that will be the platform for development of the program microturbines.

WBS 1.2 was not started and was removed from the Solar program as part of the program redirect in 2002 .

\subsection{TASK 1.3 RECUPERATOR AlLOy DEVELOPMENT}

Statement of work: WBS 1.3 Recuperator Alloy Development - Building on the results of prior alloy development at Solar, A-L, and ORNL, the program will consist of a major effort to identify materials that meet the program goals. Solar's Materials \& Processes Engineering Department will lead the effort in collaboration with A-L and ORNL. Dr. Arthur Metcalfe of AMA will be the General Consultant supporting the development effort. The development work of Solar, A-L, ORNL and Dr. Metcalfe's support activities will be programmatically conducted under separate subtasks of 1.3, but functionally integrated for an interactive team. There will be close consultation with Solar's design engineers to ensure that OEMs requirements are being addressed.

Core materials will be selected and developed that are cost effective, and meet the program performance and service life goals of the MT-OEMs (overhaul life goal of 11,000 hrs, and an overall service life goal of 45,000 hrs), for incorporation in microturbine recuperators. The effectiveness of the alloy strategies detailed in this task will be compared based on experimental data, and the most promising approaches will then be evaluated in a recuperator test on an existing advanced gas turbine.

WBS 1.3 is the major focus of this program. Six major material approaches (Task 1.3.1 to Task 1.3.6) were considered and tested for suitability to advanced recuperator applications. In each case, the creep and oxidation properties were addressed with respect to recuperator core capabilities. 


\subsubsection{Task 1.3.1 Coated Type 347 SS Foil}

Based on prior recuperator core experience with Type 347 SS, it was evident that this alloy did not have the oxidation resistance capability to endure the high temperature $\left(1350^{\circ} \mathrm{F}\right)$ and life $(45,000$ hours) requirements of this program. In order to remedy this concern, protecting the substrate material from the service environment was identified as a viable solution.

\section{Coating Selection}

After investigating several potential candidates, a two-phase glass coating, an inorganic aluminum coating, and a vitreous single-phase coating were selected.

Two-Phase Glass (TPG) Coating - Analytical Services and Material Incorporated (AS\&M) was identified as the supplier for the two-phase glass system. The coating, identified as TPG, consisted of a thin, $1 \mu \mathrm{m}$ aluminum oxide bottom layer and a 2-3 $\mu \mathrm{m}$ two-phase glass top layer.

Inorganic Aluminide Coating - Sermatech Incorporated was identified as the supplier for the inorganic aluminide coating. The coating, called Sermatel 565, consisted of a 1-2 $\mu \mathrm{m}$ barrier layer and a 20-25 $\mu \mathrm{m}$ encapsulated aluminum top layer.

Vitreous Single Phase Coating - San Diego Porcelain was selected as the suppler for the vitreous single-phase coating. The coating, Solaramic S5-8A TM, was applied in slurry form to a coating thickness of $25 \mu \mathrm{m}$. One specimen was coated in the as-received condition and a second specimen was pre-oxidized in air to form a thin oxide layer $(\sim 0.5 \mu \mathrm{m})$ prior to coating.

\section{Oxidation Testing of Coated Specimens}

Coated samples were exposed at $1300^{\circ} \mathrm{F}$ and $1400^{\circ} \mathrm{F}$ in dry air (ambient) and at $1400^{\circ} \mathrm{F}$ in air containing $10 \%$ water vapor by volume (humidified air). The ambient air exposures were performed in a box furnace. The humidified air testing was performed in tube furnaces that incorporated three-inch diameter, gas-tight tubular retorts. The airflow from a standard gas bottle was regulated and the pressure was set (Figure 4.2.1-1). The weight of all the oxidation test specimens was measured weekly and extra specimens were tested coincident with each test so that metallurgical analyses could be performed at key intervals.

The Type 347 SS foil samples coated with the AS\&M TPG coating performed well in ambient air. After 1000 hours of testing, both the $1300^{\circ} \mathrm{F}$ and $1400^{\circ} \mathrm{F}$ specimens displayed weight gains that were less than $0.20 \mathrm{mg} / \mathrm{cm}^{2}$. In contrast, the TPG coated specimens that were exposed to $1400^{\circ} \mathrm{F}$ in $10 \%$ humidified air exhibited a significantly poorer performance with an average weight gain of $8.57 \mathrm{mg} / \mathrm{cm}^{2}$ (Figure 4.2.1-2).

The Type 347 SS foil samples coated with the Sermatech inorganic aluminide coating gained weight in a controlled and relatively rapid fashion. After 1,000 hours of testing, both the $1300^{\circ} \mathrm{F}$ and $1400^{\circ} \mathrm{F}$ specimens displayed weight gains that were in excess of $1.00 \mathrm{mg} / \mathrm{cm}^{2}$. The rate of oxidation was even more dramatic in humidified air with the specimen exhibiting a weight gain of $16.94 \mathrm{mg} / \mathrm{cm}^{2}$, which was more than 15 times greater than the weight gain for ambient air exposures (Figure 4.2.1-3). 


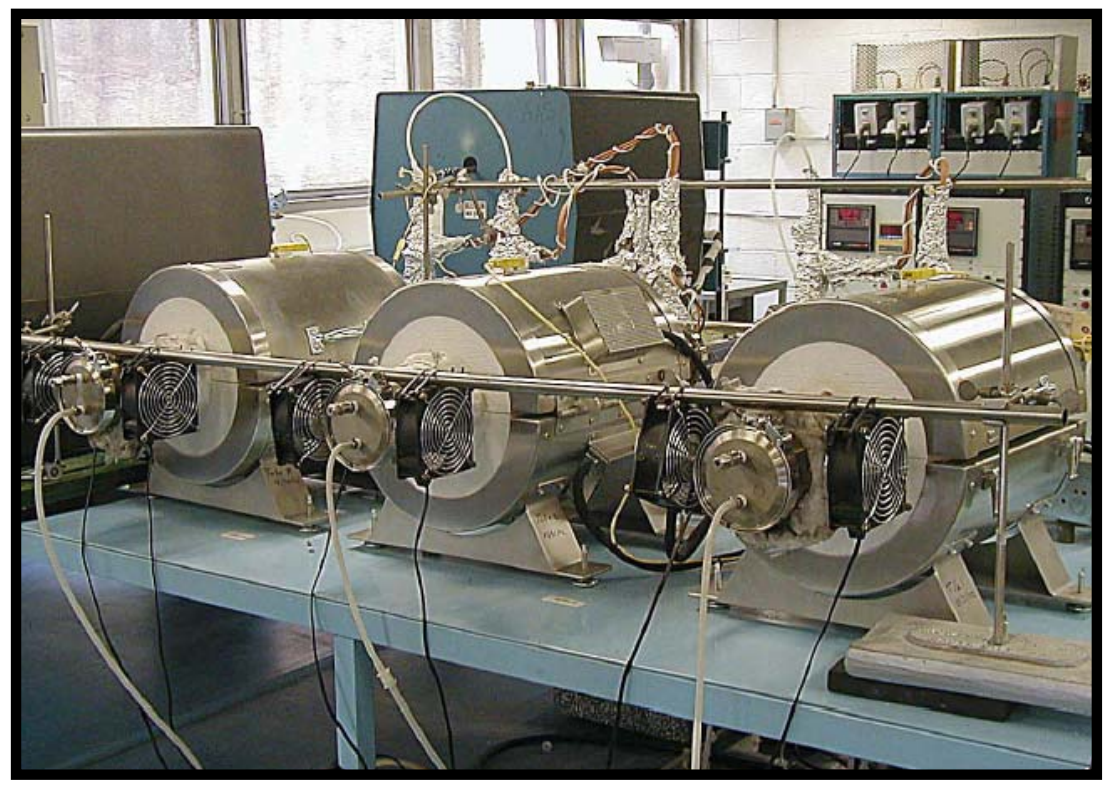

Figure 4.2.1-1. Oxidation Test Fixture for Humidified Air Exposure Testing

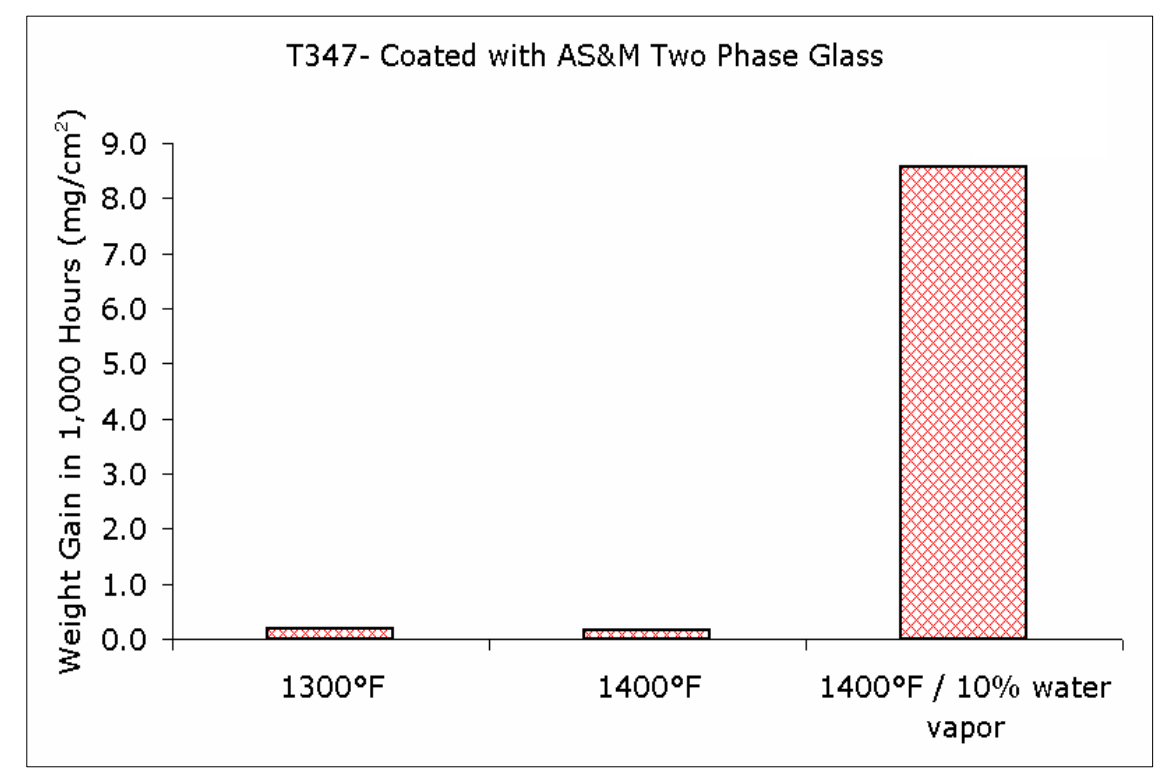

Figure 4.2.1-2. Total Weight Gain for TPG-coated Type 347 SS

The Type 347 SS foil samples that were coated with the Solaramic S5-8A ${ }^{\text {TM }}$ were only exposed to $1400^{\circ} \mathrm{F}$ in $10 \%$ humidified air. Both specimens oxidized rapidly and due to specimen degradation, exposure testing was discontinued after 500 hours. After testing, the overall weight gain of the as-coated specimen was $8.56 \mathrm{mg} / \mathrm{cm}^{2}$ and the pre-oxidized specimen had a weight gain of $8.99 \mathrm{mg} / \mathrm{cm}^{2}$ (Figure 4.2.1-4). 


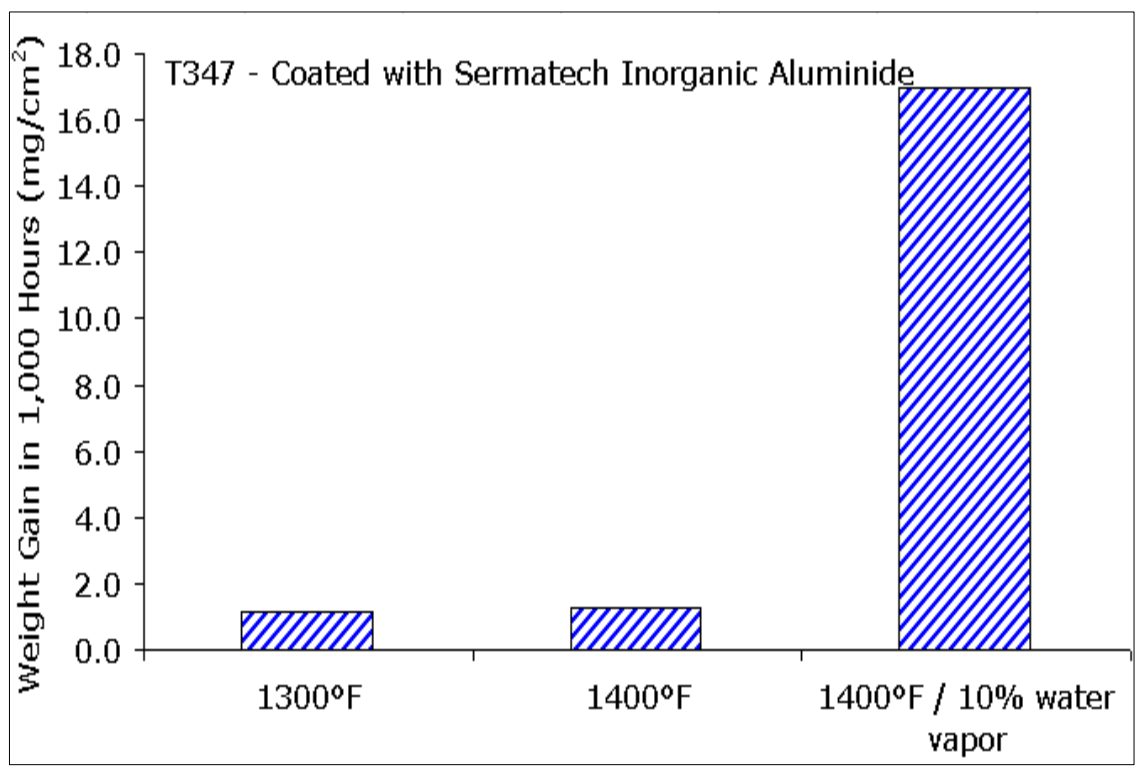

Figure 4.2.1-3. Total Weight Gain for Type 347 SS Foil Coated with Sermatech Inorganic Aluminide

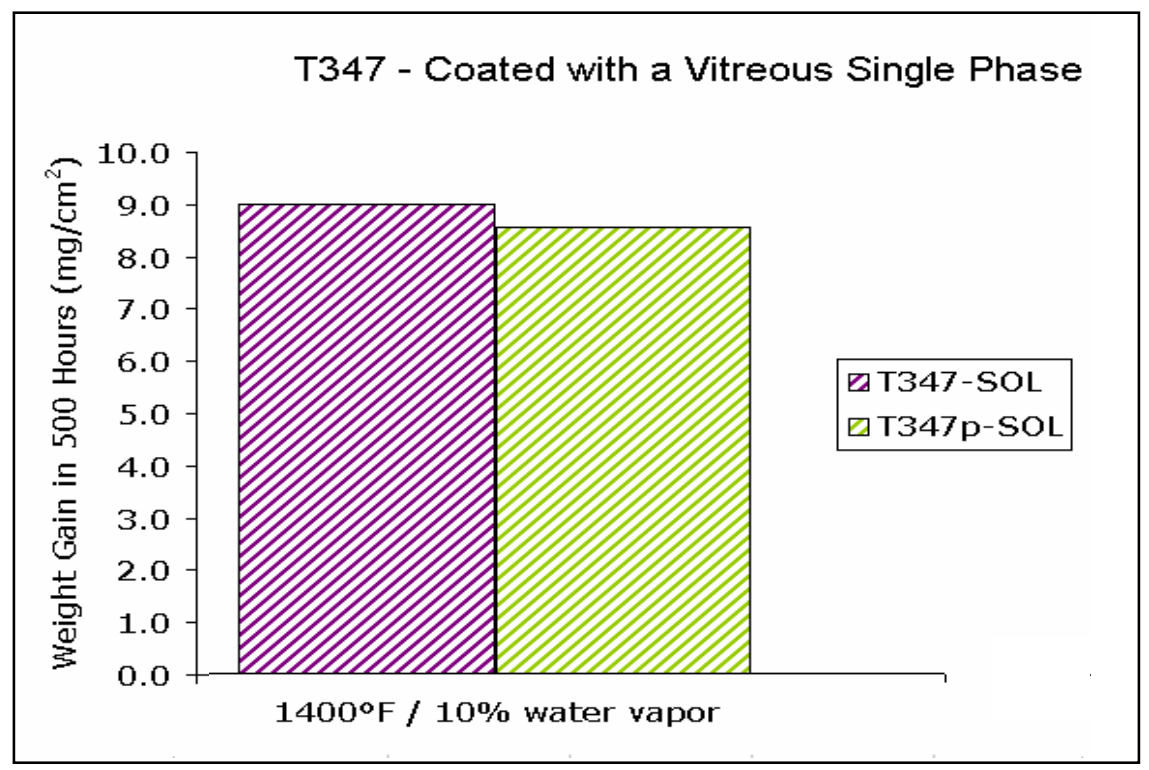

Figure 4.2.1-4. Total Weight Gain for Solaramic S5-8A ${ }^{\mathrm{TM}}$ Coated Type 347 SS Foil as Coated (purple) and Pre-oxidized (green)

Metallographic cross-sections were prepared through all of the exposed specimens. The coated Type 347 SS foil specimens that were exposed in ambient air displayed a compact oxide film with no appreciable thickness. In contrast, the specimens that were exposed to $10 \%$ humidified air at $1400^{\circ} \mathrm{F}$ for 500 hours displayed complete degradation of the coatings and extensive attack of the substrate (Figure 4.2.1-5). 


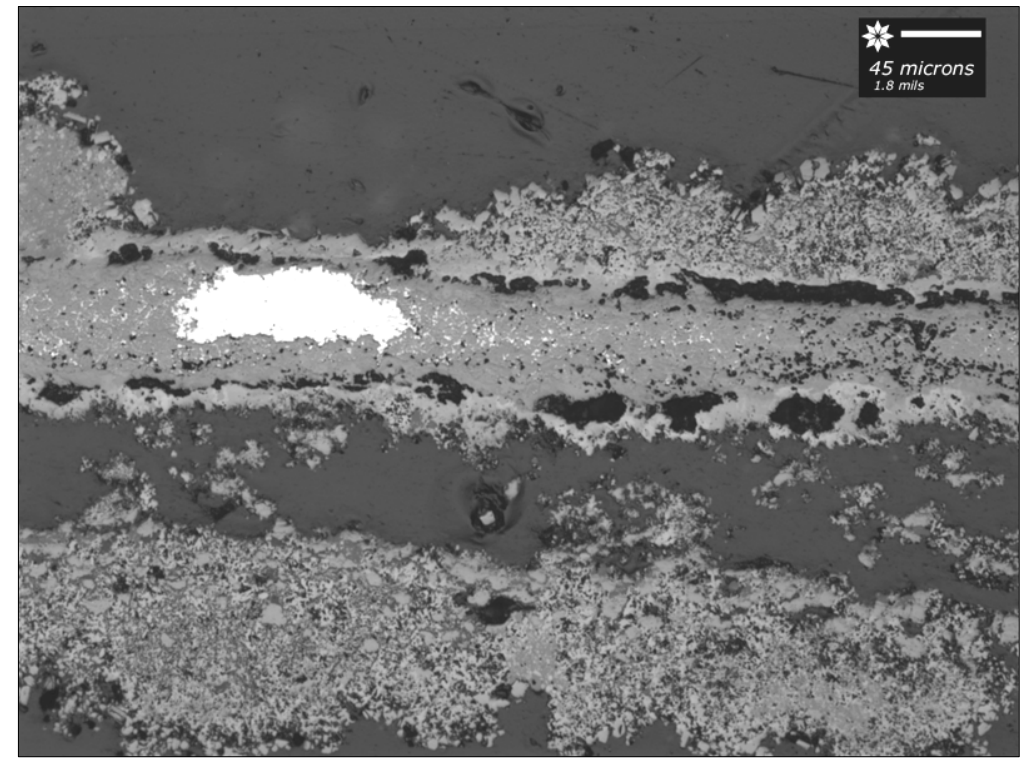

Figure 4.2.1-5. Metallographic Cross-section of a Solaramic S5-8A ${ }^{\text {TM }}$ Coated Type 347 SS Foil after Exposure

\section{Coating Selection for Recuperator Core Testing}

Exposure testing and evaluation of the coatings applied to Type 347 SS revealed that the coating systems did not result in superior short-term (500-1,000 hours) oxidation resistance in a humidified air environment. Given such poor performance in an environment comparative to recuperator service, none of the coating systems were selected for application and exposure testing on a recuperator core. Creep testing of coated samples was also deemed unnecessary since the oxidation results were so poor. A report on this task was incorporated into the WBS 1.3 Topical Report.

\subsubsection{Task 1.3.2 Creep Resistant Type 347 SS Foil}

The higher temperature $\left(1350^{\circ} \mathrm{F}\right)$ and longer life $(45,000$ hours $)$ goals of this program raised questions and concerns regarding the creep resistance of Type $347 \mathrm{SS}$ in the recuperator environment. In order to address these requirements, the development of a creep resistant Type 347 SS foil was pursued.

\section{Development Process}

The process for improving the creep strength of Type 347 SS foil was developed with the intent of maintaining the compositional requirements of alloy specification and limiting the grain size to ASTM \#8.5 to \#11.0 so the foil could be processed. Based on these and other factors, optimizing the final size and distribution of the niobium-carbides in the foil product was deemed the best way to increase creep strength. In order to produce the foil material, much thicker Type 347 SS sheet stock is usually processed through a number of rolling and heat-treating steps. The size and distribution of the niobium-carbide precipitates in the final foil form are primarily a function of reduction steps and annealing conditions used at the end of the manufacturing process. 
Based on this approach, multiple laboratory ingots, each weighing approximately fifty pounds, were melted and then processed. During the processing steps, the percent reduction, the annealing temperature, and the annealing time were varied so that a relationship between processing parameters and creep strength could be identified.

\section{Oxidation Testing}

Due to the time constraints of the program, the oxidation test specimens were not from the laboratory heats previously described; however, the compositions of all the oxidation specimens met the compositional requirements of AMS 5512 for Type 347 SS foil and were deemed "compositionally" representative of the laboratory heats. The Type 347 SS foil specimens were tested at $1300^{\circ} \mathrm{F}$ and $1400^{\circ} \mathrm{F}$ in ambient air as well as in $7 \%$ and $10 \%$ humidified air. In order to establish the baseline oxidation behavior for this Type 347 SS foil, test results were evaluated after 1,000 hours of exposure. These specimens were exposed in the same fashion as the coated Type 347 SS specimens and were also weighed weekly.

After 1,000 hours of testing in ambient air, the specimen that was exposed at $1300^{\circ} \mathrm{F}$ displayed a weight gain of $0.07 \mathrm{mg} / \mathrm{cm}^{2}$ and the specimen that was exposed at $1400^{\circ} \mathrm{F}$ displayed a weight gain of $0.17 \mathrm{mg} / \mathrm{cm}^{2}$. Exposure testing indicated that the weight gain in $7 \%$ humidified air at $1300^{\circ} \mathrm{F}$ after 1,000 hours was $2.42 \mathrm{mg} / \mathrm{cm}^{2}$ and $3.92 \mathrm{mg} / \mathrm{cm}^{2}$ at $1400^{\circ} \mathrm{F}$. The weight gain in $10 \%$ humidified air at $1300^{\circ} \mathrm{F}$ after 1,000 hours was $4.09 \mathrm{mg} / \mathrm{cm}^{2}$. Upon completing the 1,000 hours exposure testing of Type $347 \mathrm{SS}$ foil, test results indicated that the addition of moisture to the test environment had caused a 20 - to 60 -fold weight gain increase in comparison with ambient air exposures (Figure 4.2.2-1).

Metallurgical sections through the Type 347 SS specimens revealed that the coupons that were exposed in ambient air had a relative thin surface scale while those that were exposed to humidified air displayed a thick duplex scale that was consistent with the significant increase in weight gain. This scale was several microns thick and consisted of an iron-rich region at the interior interface and a chromium-rich exterior surface (Figure 4.2.2-2).

\section{Creep Testing}

Subsequent to the production of Type $347 \mathrm{SS}$ foil from the lab heats, creep testing was performed on dog-bone shaped coupons taken transverse to the rolling direction from each laboratory heat The testing was performed at a test temperature of $1350^{\circ} \mathrm{F}$ and a stress of $7 \mathrm{ksi}$ to 5\% creep. Creep test results indicated that the specimen with the hotter final anneal (HFA) displayed properties that were clearly superior to the other specimens, displaying a time to $5 \%$ creep of 2,100 hours, which was 2.5 times longer than any other specimen (Figure 4.2.2-3).

Based on the comparative creep testing results, the laboratory produced HFA foil was creep tested in more detail. For each test condition, the resulting times to $1 \%$ and $5 \%$ creep were converted to Larson-Miller parameters and compared to standard nominal creep curves for typical Type 347 SS 0.004 " foil. Analyses indicated that at $17 \mathrm{ksi}$ and $11 \mathrm{ksi}$, the creep properties of the HFA foil were either at or below the standard Type 347 SS foil curve. However, at $7 \mathrm{ksi}$ the creep resistant properties for the HFA foil was well above the standard Type 347 SS curve indicating that HFA foil had superior creep strength in the lower stress (7 ksi) region (Figure 4.2.2-4). 


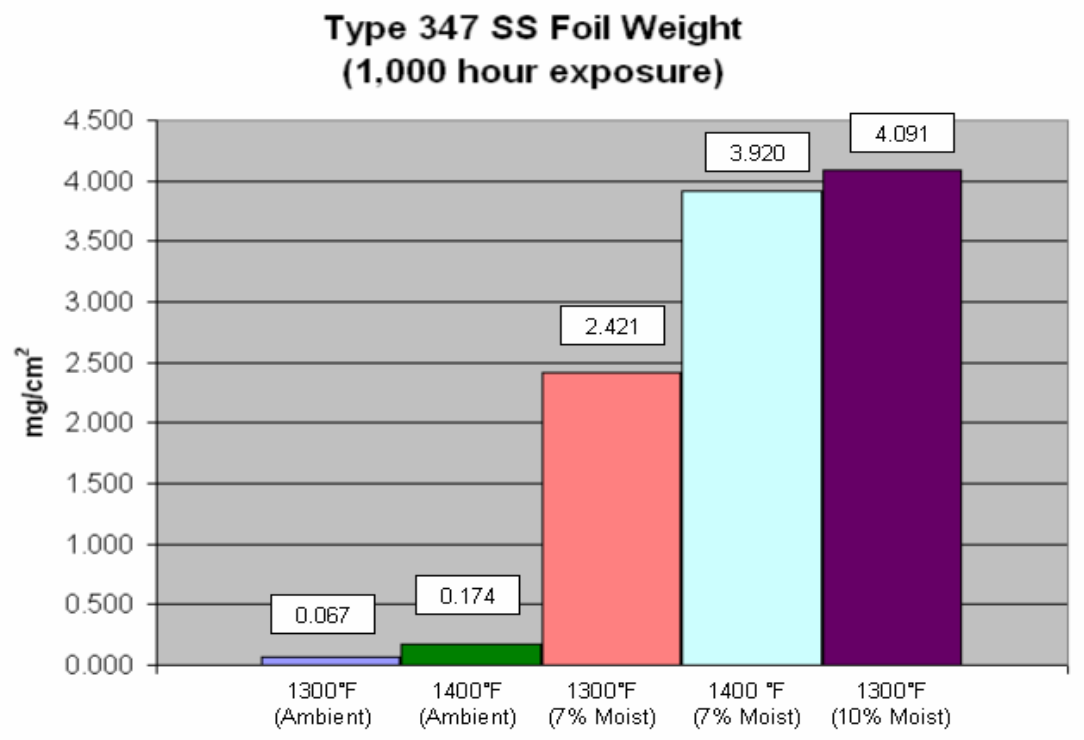

Figure 4.2.2-1. Comparative Weight Gains of Type 347 SS Foil

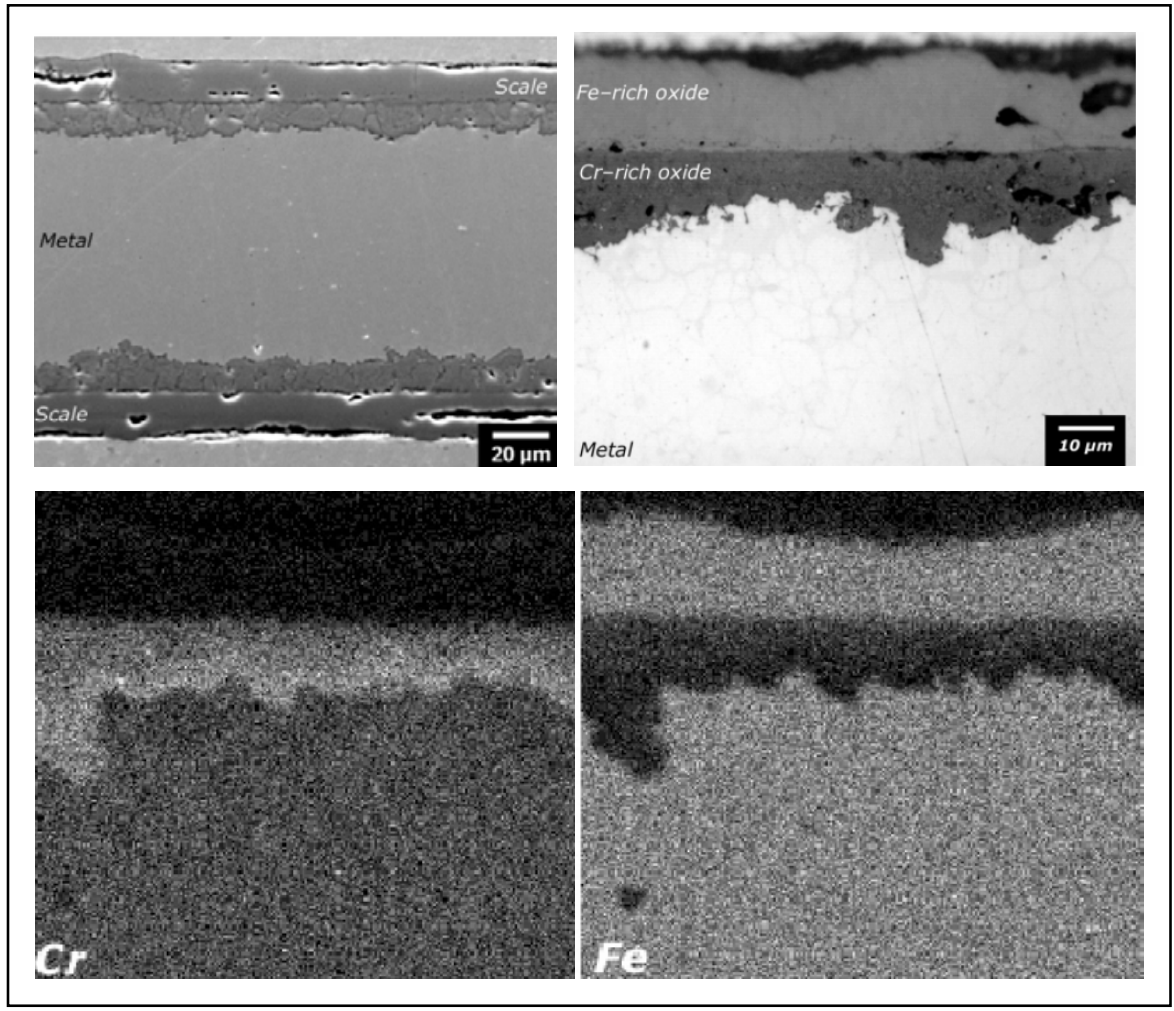

Figure 4.2.2-2. Metallurgical Cross-sections through a Type 347 SS Specimen that was Exposed for 1,000 Hours at $1300^{\circ} \mathrm{F}$ in $10 \%$ Humidified Air 


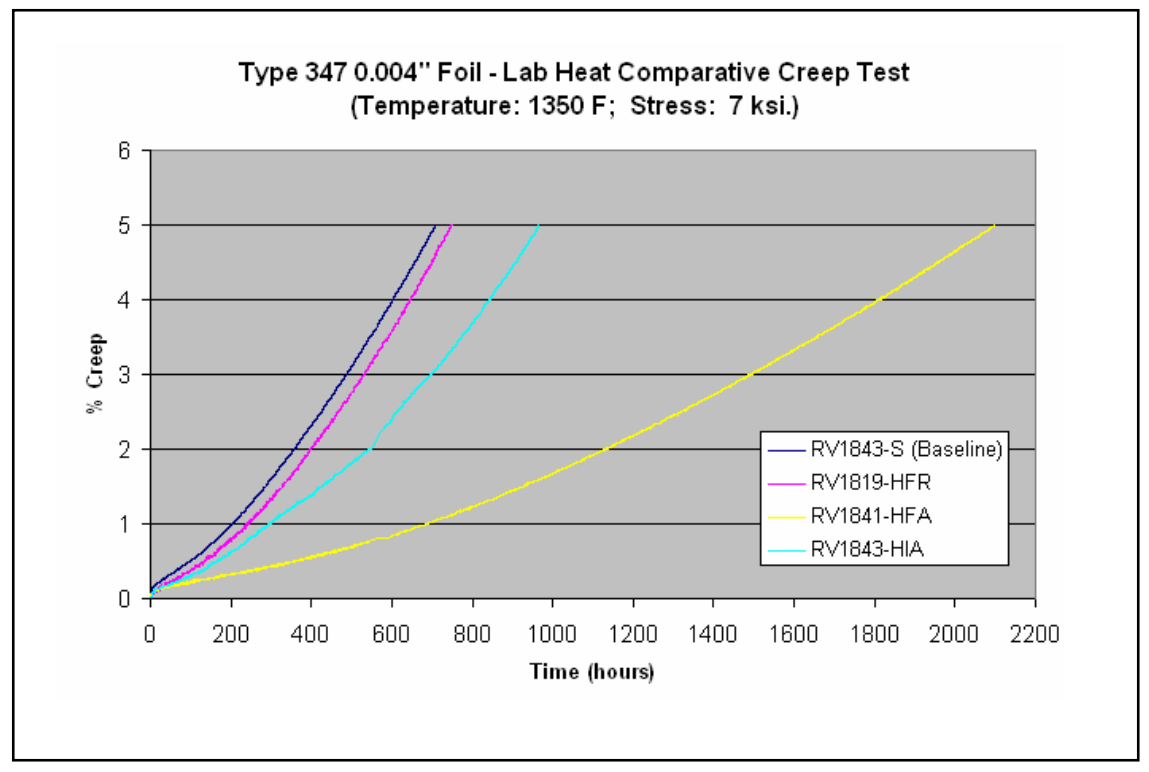

Figure 4.2.2-3. Type 347 SS Foil Creep Curves of Laboratory Heats

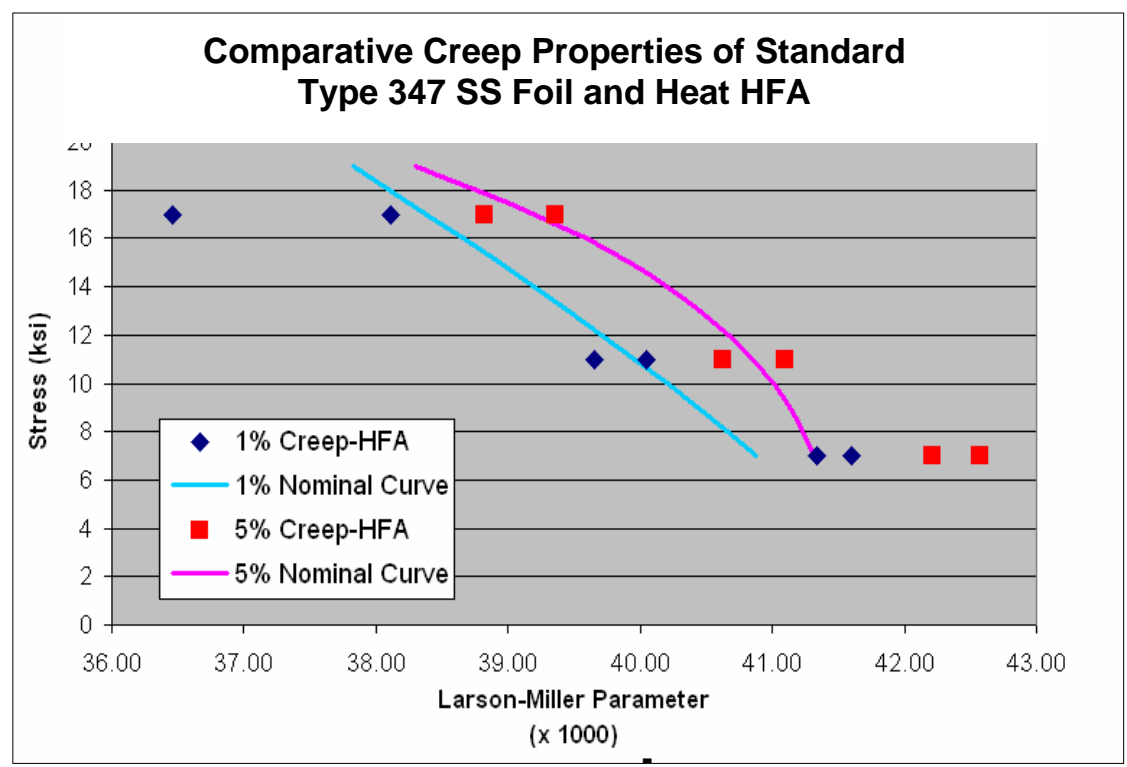

Figure 4.2.2-4. Comparative Creep Properties of Standard Type 347 SS Foil and Heat HFA

The microstructural features of several representative Type 347 SS foil specimens from lab heats were evaluated in order to characterize the foil materials. An unexposed specimen from the HFA heat displayed fewer coarse niobium-carbides than the other laboratory heats, which may indicate that the higher final annealing temperature dissolved a higher volume of niobiumcarbides. After creep testing, the HFA specimen displayed a comparatively larger volume of fine secondary precipitates within the grains than other creep tested specimens. A notably large number of dislocations were tangled around the fine precipitates and the grain boundaries. The sample also displayed dislocations in various regions of the matrices with some dislocations 
tangled around the precipitates or at the grain boundaries. The grain size before and after testing ranged from ASTM \#10 to \#11 indicating that no appreciable grain growth had occurred during creep testing.

\section{Selection of Mill Processing Parameters}

Creep testing of Type 347 SS foil specimens that were processed by different manufacturing methods determined that the HFA material displayed greater creep resistance, making the associated manufacturing process the preferred approach for improving the creep strength of Type 347 SS foil.

\section{Production and Characterization of a Mill Heat}

As part of the program plan, this was identified as a decision point to determine if producing a creep resistant Type $347 \mathrm{SS}$ foil recuperator core was a viable option. Although it was proven that the creep strength could be improved by changing the production process, the poor oxidation resistance of Type $347 \mathrm{SS}$ in moist environments appears to be a limiting factor. Oxidation rates in excess of $4 \mathrm{mg} / \mathrm{cm}^{2}$ after 1,000 hours in $10 \%$ humidified air at $1300^{\circ} \mathrm{F}$ indicated that this alloy was not suited for recuperator service under the program design directive. Since oxidation resistance is primarily governed by the composition of the alloy, it was determined that producing a mill heat of creep resistant Type 347 SS recuperator would not be beneficial because greater oxidation resistance is needed for this application. A report on this task was incorporated into the WBS 1.3 Topical Report.

\subsubsection{Task 1.3.3 Advanced Austenitic (AA) Foil}

At the initiation of this DOE program, work on the development of a recuperator foil alloy was in progress with Solar, A-L, ORNL, and others contributing to the project. At that time, the potential of several alloys had been evaluated and a $20 \%$ chromium- $25 \%$ nickel-niobium stabilized austenitic material had been selected as the prime thin foil core material candidate. For ease of discussion, the alloy was identified as Advanced Austenitic or "AA".

\section{Development Process}

AA foil material was identified as the primary candidate for a new recuperator alloy due to a number of perceived properties. Those potential properties included good oxidation resistance, due to high chromium content; good creep strength due to niobium-carbide precipitation; good manufacturing capabilities due to the austenitic matrix; and relative low cost, because the alloy would be iron-based.

Near the initiation of this program, A-L produced a pilot coil that was vacuum induction melted (VIM) as a 300-pound pilot coil. This material was processed to the finished nominal thickness of 0.004" and was the initial material to be characterized. Later in the program, three 30-pound lab heats of AA material were melted and rolled down to a thickness of $0.015 \%$. When these heats were subsequently rolled to 0.004 ", the percent reduction, the annealing temperature, and the annealing time were varied so that a relationship between processing parameters and creep strength could be identified. Based on testing and characterization, the optimum processing condition would then be identified and a production heat would be processed accordingly. Foil 
and components produced from the production heat would then be used to build a recuperator for testing.

As previously noted, the oxidation resistance of a recuperator alloy is driven by the chemical composition of the material. With respect to AA, the primary elements intended to promoted oxidation resistance were chromium and nickel. Chemical analyses of the 300 pound pilot heat and the three 30 pound lab heats (identified as RV1832, RV1833, and RV1834) indicated that the heats had similar composition and were acceptable for further processing (Table 4.2.3-1).

Table 4.2.3-1. Composition of AA Foil Material Heats

\begin{tabular}{|l||c|c|c|c|}
\hline \multicolumn{1}{|l||}{ Element } & \multicolumn{4}{|c|}{$\begin{array}{c}\text { Actual Composition } \\
\text { (Weight Percent) }\end{array}$} \\
\cline { 2 - 5 } & Pilot Heat & RV1832 & RV1833 & RV1834 \\
\hline \hline Chromium & 21.0 & 20.3 & 20.2 & 20.2 \\
\hline Nickel & 26.0 & 25.6 & 25.6 & 25.6 \\
\hline Manganese & 1.7 & 1.0 & 1.0 & 1.0 \\
\hline Molybdenum & 1.53 & 1.55 & 1.54 & 1.46 \\
\hline Silicon & 0.41 & 0.42 & 0.44 & 0.42 \\
\hline Carbon & 0.087 & 0.067 & 0.076 & 0.064 \\
\hline Nitrogen & 0.11 & 0.13 & 0.13 & 0.12 \\
\hline Phosphorus & 0.004 & 0.035 & 0.026 & 0.027 \\
\hline Boron & 0.003 & 0.003 & 0.003 & 0.003 \\
\hline Niobium & 0.30 & 0.30 & 0.30 & 0.30 \\
\hline Iron & Balance & Balance & Balance & Balance \\
\hline
\end{tabular}

\section{Oxidation Testing}

AA foil specimens were tested at $1300^{\circ} \mathrm{F}$ and $1400^{\circ} \mathrm{F}$ in ambient air, $7 \%$ humidified air, and $10 \%$ humidified air. As with the Type 347 test specimens, the initial comparative test duration was 1,000 hours and multiple specimens were tested at each condition so average behavior could be determined and metallurgical analysis could be performed.

After 1,000 hours of testing in ambient air, the specimen that was exposed at $1300^{\circ} \mathrm{F}$ displayed a weight gain of $0.08 \mathrm{mg} / \mathrm{cm}^{2}$ and the specimen that was exposed at $1400^{\circ} \mathrm{F}$ displayed a weight gain of $0.23 \mathrm{mg} / \mathrm{cm}^{2}$. Exposure testing indicated that the weight gain in $7 \%$ humidified air at $1300^{\circ} \mathrm{F}$ after 1,000 hours was $0.08 \mathrm{mg} / \mathrm{cm}^{2}$ and the weight gain at $1400^{\circ} \mathrm{F}$ was $0.23 \mathrm{mg} / \mathrm{cm}^{2}$. The weight gain in $10 \%$ humidified air at $1300^{\circ} \mathrm{F}$ after 1,000 hours was $0.07 \mathrm{mg} / \mathrm{cm}^{2}$. This data indicated that at ambient conditions, the AA foil weight gain was slightly higher than for Type 347 Foil; however, in contrast to Type 347 foil, the addition of moisture resulted in no appreciable acceleration in weight gain. It was also evident that AA specimens exposed to humidified air displayed weight gains that were 15 to 50 times less than those for Type $347 \mathrm{SS}$ foil (Figure 4.2.3-1).

Based on the positive 1,000 hour AA exposure results, oxidation testing of AA was continued for longer periods of time and testing was initiated at $1500^{\circ} \mathrm{F}$ in $7 \%$ humidified air so that a predictive model could be developed. The testing at $1300^{\circ} \mathrm{F}$ in $10 \%$ humidified air was 
continued to 10,017 hours, the testing at $1400^{\circ} \mathrm{F}$ in $7 \%$ humidified air was continued to 14,956 hours, and the testing at $1500^{\circ} \mathrm{F}$ in $7 \%$ humidified air was continued to 1,832 hours. Upon completion of this exposure testing, a calculated curve was fitted to the data (Figure 4.2.3-2) and a limited lifetime phenomenological model was developed so that a maximum exposure temperature for a prescribed duration could be identified. Based on this oxidation model, the predicted operating temperature for the program life goal of 45,000 was near the program temperature goal of $1350^{\circ} \mathrm{F}$.

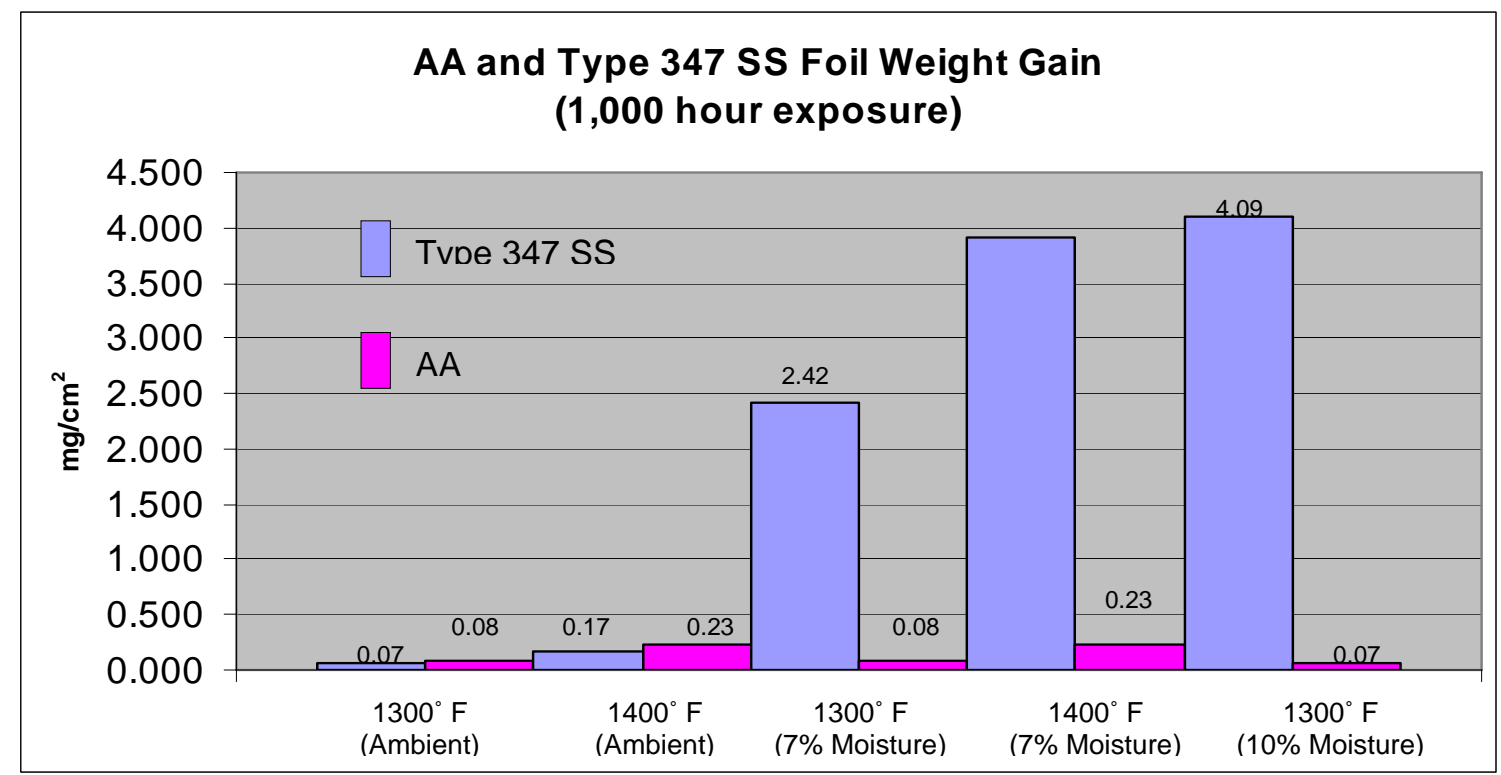

Figure 4.2.3-1. Comparative Weight Gain of Type 347 and AA Foil after 1,000 Hours of Exposure

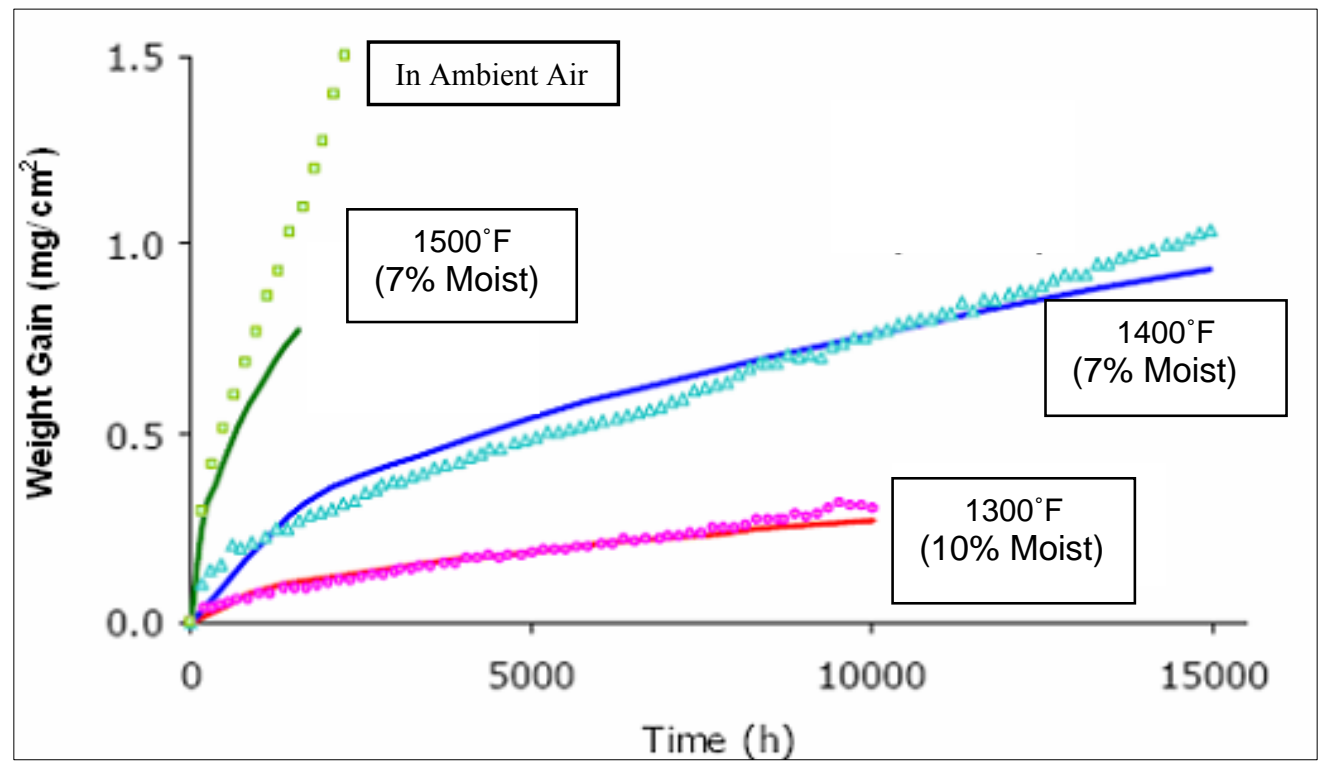

Figure 4.2.3-2. Weight Gain and Fitted Curves for AA Foil Exposed to $1300^{\circ} \mathrm{F}, 1400^{\circ} \mathrm{F}$, and $1500^{\circ} \mathrm{F}$ 
Metallurgical sections through AA foil specimens that had been exposed for prolonged periods revealed a thin, compact duplex oxide scale with the only notable differences between specimens being the oxide thickness with respect to exposure time. For example, the specimen exposed for 5,000 hours at $1300^{\circ} \mathrm{F}$ in $10 \%$ humidified air had an average scale thickness of $0.8 \mu \mathrm{m}$ and the specimen exposed under the same conditions for 10,000 hours had an average scale thickness of $1.5 \mu \mathrm{m}$ (Figure 4.2.3-3). Analysis of the duplex surface oxide identified the layer in contact with the substrate as primarily chromium oxide $\left(\mathrm{Cr}_{2} \mathrm{O}_{3}\right)$ while the outer layer appeared to be a manganese chromate spinel $\left(\mathrm{MnCrO}_{4}\right)$. It was also noted that after prolonged exposure periods (greater than 5,000 hours) the oxide scales that formed in ambient air were generally thicker than the scale that formed in humidified air.

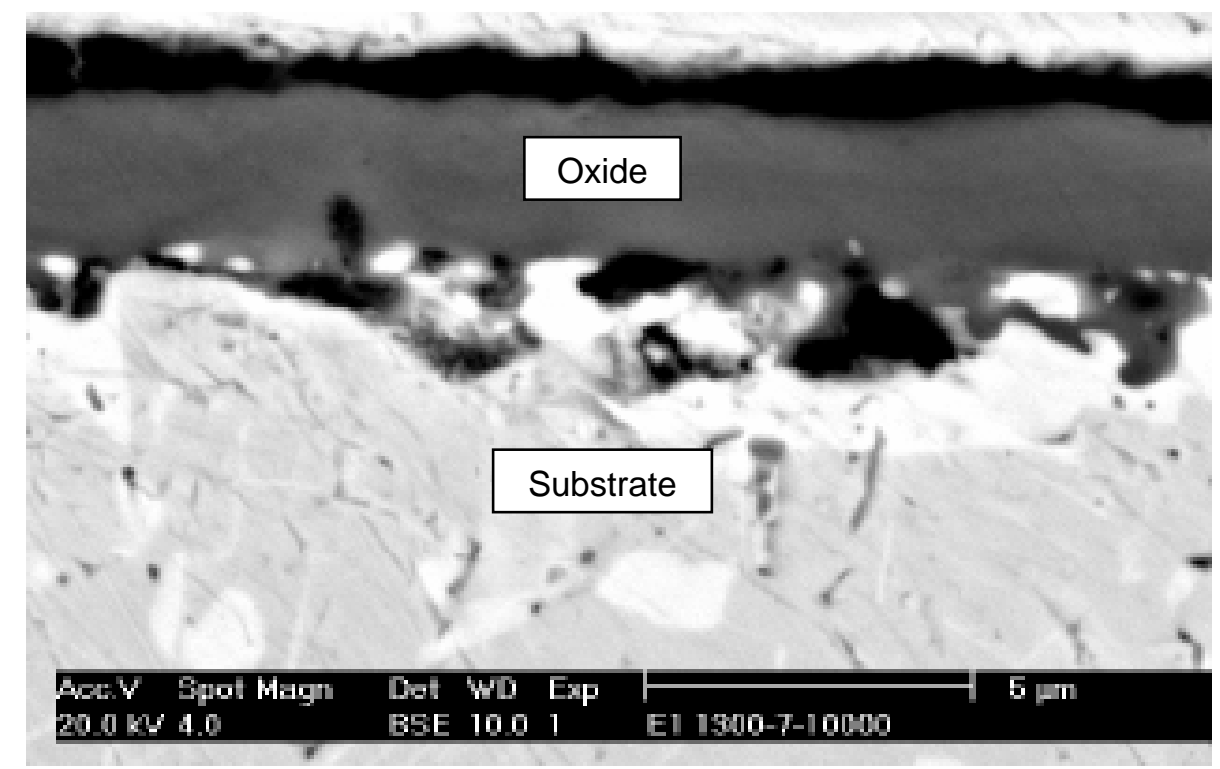

Figure 4.2.3-3. SEM Photomicrograph of Cross-section Through an AA Specimen that was Exposed for 10,000 Hours at $1300^{\circ} \mathrm{F}$ in $10 \%$ Humidified Air

\section{Creep Testing}

As with Type 347 SS, the creep strength of AA foil was developed with the intent of maintaining the compositional goals of the alloy (see Table 4.2.3-1) and maintaining a grain size of ASTM $\# 8.5$ to \#11.0 so the foil could be processed. Based on these and other factors, optimizing the final size and distribution of the niobium-carbides in the foil product was deemed the best way to increase creep strength. The size and distribution of the niobium-carbide precipitates in the final foil form are primarily a function of reduction steps and annealing conditions used at the end of the manufacturing process. Accordingly, multiple processing approaches were identified and attempted. During the processing steps, the percent reduction, the annealing temperature, and the annealing time were varied so that a relationship between processing parameters and creep strength could be identified.

Creep testing was performed on dog-bone shaped coupons taken transverse to the rolling direction from each of the laboratory heats. The testing was performed at a test temperature of $1350^{\circ} \mathrm{F}$ and a stress of $7 \mathrm{ksi}$ to $1 \%$ creep. Creep test results indicated that the specimen with the hotter final anneal (HFA) had properties that were clearly superior to those of the other specimens, displaying a time to $1 \%$ creep of 4,400 hours, which was $20 \%$ longer than for any 
other AA specimen and more than 6 times longer than for the Type 347 SS HFA specimen. In order to more fully characterize the creep properties of AA in the HFA condition, extensive testing was performed at stresses up to $17 \mathrm{ksi}$. Data from this testing was then used to create a Larson-Miller curve that relates time and temperature for predicting creep behavior at a given stress $\left(\mathrm{LMP}=\mathrm{T}^{*}[20+\log \{\mathrm{t}\}]\right.$, where $\mathrm{T}$ is in ${ }^{\circ} \mathrm{R}$ and $\mathrm{t}$ is in hours.) For an operating stress of $7 \mathrm{ksi}$ at $1350^{\circ} \mathrm{F}$, the average time to $1 \%$ creep would be greater than 5,800 hours, which was significantly longer than the 460 hours predicted for Type 347 SS (Figure 4.2.3-4).

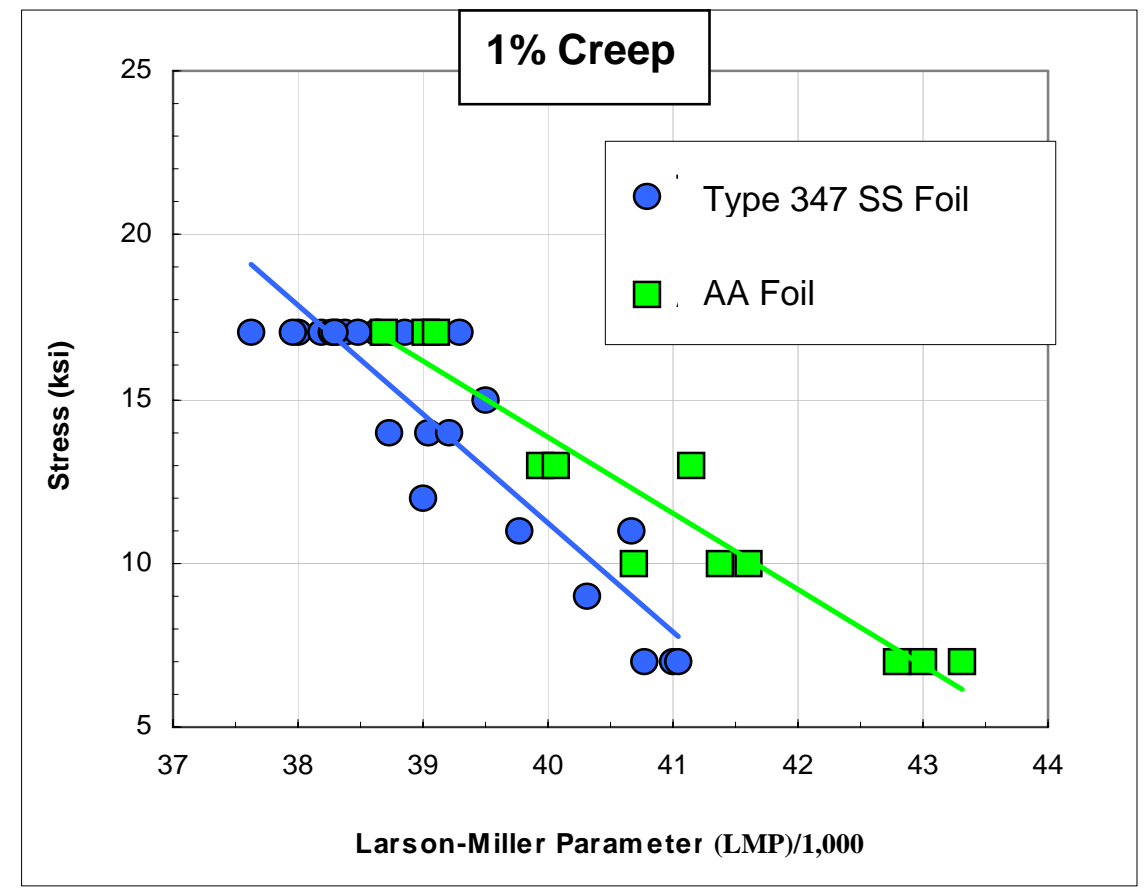

Figure 4.2.3-4. Comparative 1\% Creep Larson-Miller Curve for Type 347 SS and AA Foil

The microstructural features of several representative AA specimens from lab heats were evaluated in order to characterize the foil materials. As processed, AA foil displayed fewer coarse niobium-carbides (primary carbides) than Type 347 SS, which may be due to the presence of molybdenum that tends to decrease diffusivity. However, smaller, secondary precipitates were observed throughout the matrix with very few precipitates at the grain boundaries. The grain size of the foil material prior to creep testing ranged from ASTM \#10 to \#11. Following creep testing, the grain boundaries were almost completely covered with fine precipitates and the matrix also displayed a higher volume of precipitates. Dislocation lines were stacked-up at the precipitates. The improved creep behavior of the foil was apparently due to presence of copious intergranular and intragranular precipitates that impaired dislocation movement. The grain size following creep exposure ranged from ASTM \#9 to \#11, indicating that some grain coarsening may have occurred during creep testing.

\section{Selection, Production and Characterization of a Mill Heat for a Recuperator}

In order to verify the ability to fabricate AA foil, several sub-size aircells were manufactured. The manufacturing process consisted of folding (corrugating the foil), pressing and shearing the folded structure to the proper size, and the welding bar material around the surface of the foil to 
provide structural integrity. Non-destructive and destructive metallurgical analysis indicated that the AA material could be processed into recuperator components (Figure 4.2.3-5).

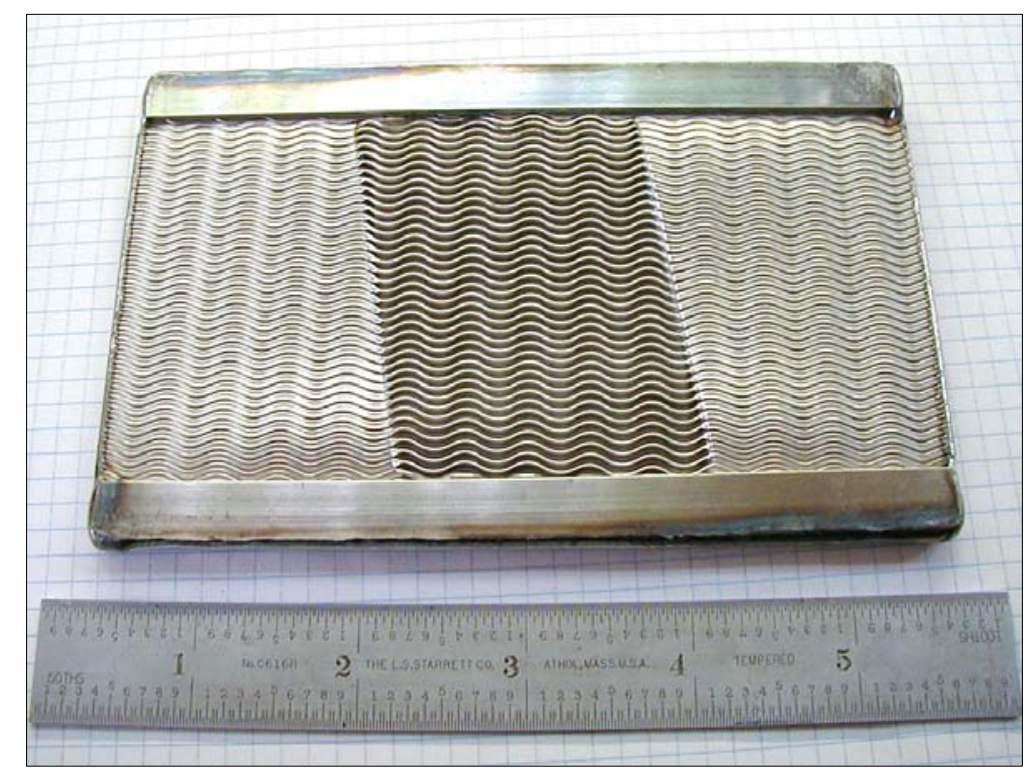

Figure 4.2.3-5. Sub-size Air Cell Manufactured from AA Foil Material

Based on the performance of pilot and lab heats of AA foil material, the HFA processing approach was selected as the method for producing a mill heat of AA foil that would be used to build recuperator components for recuperator testing. A mill heat ( $>30,000$ pounds) of AA material was melted in December 2002 and processing of sheet, plate, and foil forms of various thicknesses and widths, in order to supply material to make recuperator components, was initiated shortly thereafter. The processing proceeded as planned for the thicker section, but a major setback occurred as the 0.004 " foil was being reduced to the final thickness. During the continuous rolling operation, the foil material did not catch the spool properly and the entire 0.004 " requirement for the recuperator core material was destroyed. Given the tight schedule of the program and the long lead-time for processing foil, it was not feasible to manufacture more AA foil, so an alternate approach to testing the recuperator foil material had to be implemented (see Section 4.5 Task 1.6 Recuperator Endurance Test).

Mechanical testing of sheet and plate product at both room temperature and elevated temperatures was performed. Test results indicated that the typical room temperature tensile strength, yield strength, and elongation were 103-113 ksi 50-59 ksi, and 35-41\%, respectively (Figures 4.2.3-6 to 4.2.3-8). Full characterization of the mill produced AA material was initiated and test results indicated that the material properties were similar to those of the lab-produced material indicating that the transfer of technology from the lab to the mill was successful. In preparation to market the AA material to the microturbine recuperator manufacturers and other industries, A-L named the AA material AL 20-25+Nb ${ }^{\mathrm{TM}}$. Technical brochures and presentations were prepared and the alloy is presently commercially available. A report on this task was incorporated into the WBS 1.3 Topical Report. 


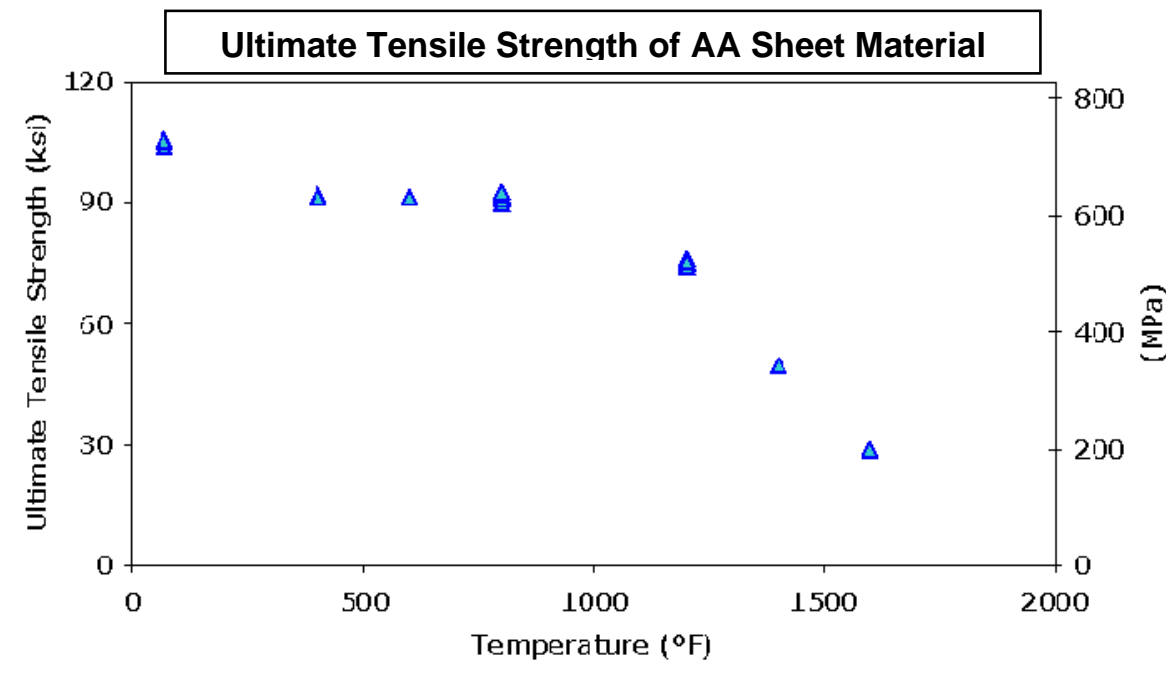

Figure 4.2.3-6. Ultimate Tensile Strength of AA Sheet Material

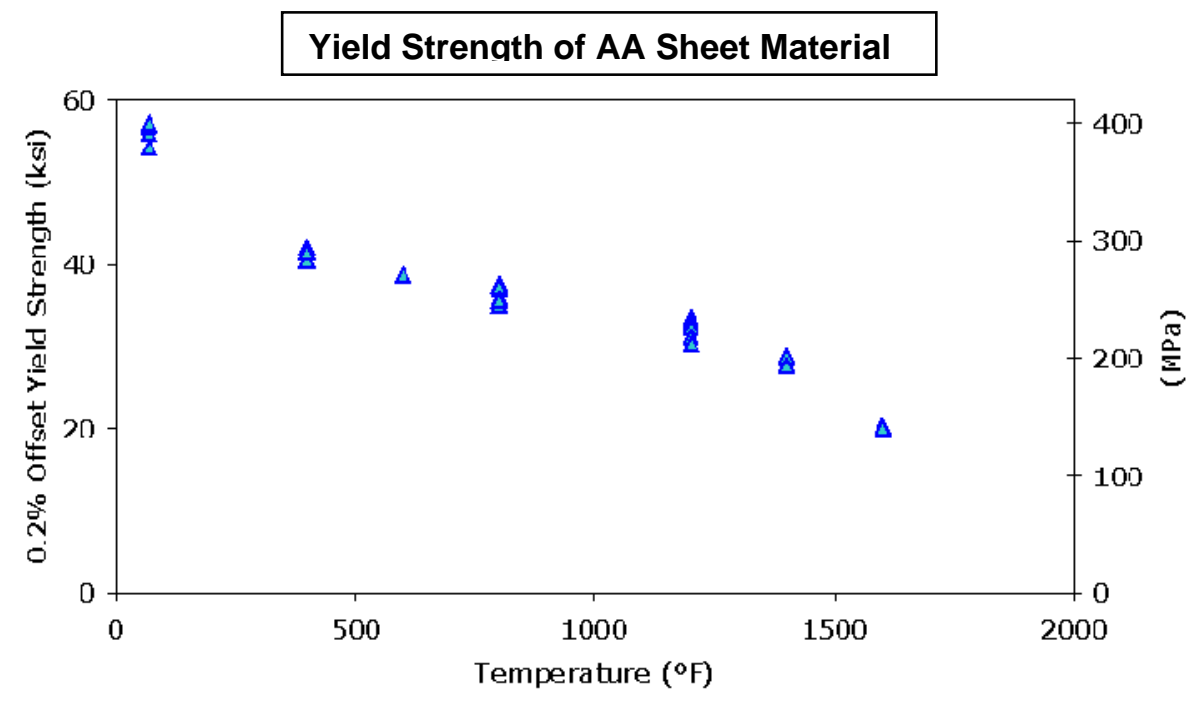

Figure 4.2.3-7. Yield Strength of AA Sheet Material

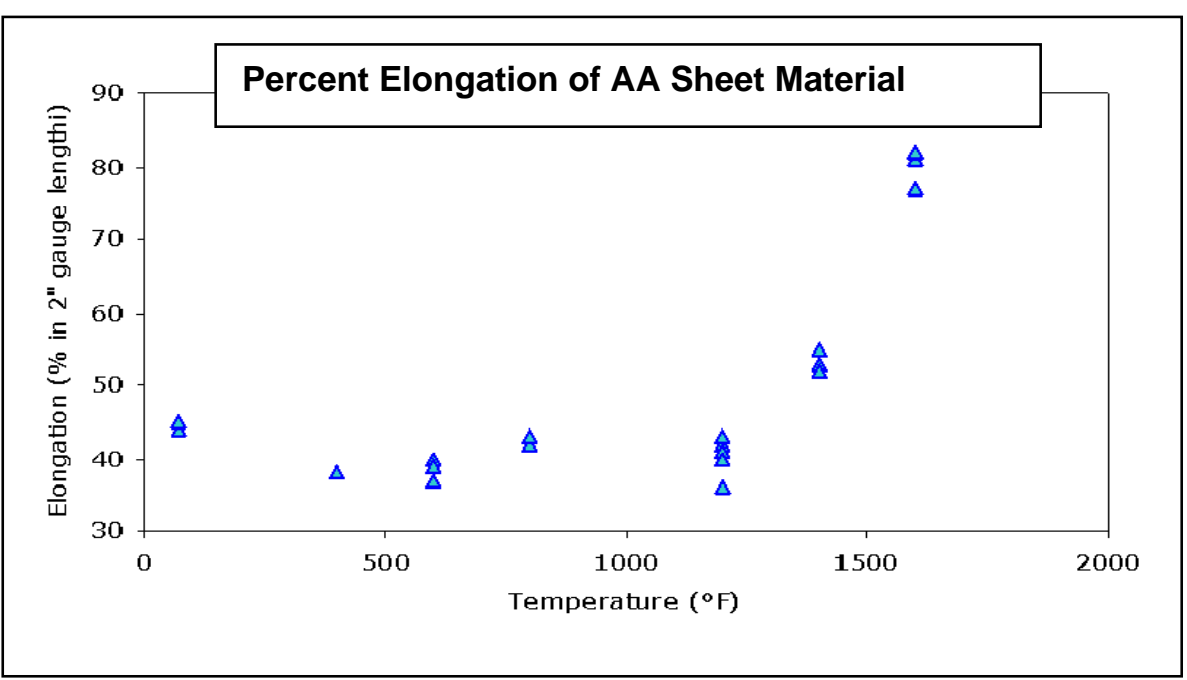

Figure 4.2.3-8. Percent Elongation of AA Sheet Material 


\subsubsection{Task 1.3.4 Coated Advanced Austenitic Alloy Foil}

When the project was initiated, the benefits of a new recuperator alloy (now identified as AA) were unknown and the need to coat this new alloy with a coating in a fashion similar to Type 347 SS (see 4.2.1 Task 1.3.1) was pursued. As with Task 1.3.1, three coating suppliers were selected and three coating systems were evaluated. Foil specimens for coating development were prepared and shipped to the respective coating suppliers.

Two-Phase Glass Coating - Analytical Services and Material Incorporated (AS\&M) was identified as the suppler for the two-phase glass system. The coating, identified as TPG, consisted of a thin, $1 \mu \mathrm{m}$ aluminum oxide bottom layer and a 2-3 $\mu \mathrm{m}$ two-phase glass top layer.

Inorganic Aluminide Coating - Sermatech Incorporated was identified as the suppler for the inorganic aluminide coating. The coating, called Sermatel 565, consists of a 1-2 $\mu \mathrm{m}$ barrier layer and a 20-25 $\mu \mathrm{m}$ encapsulated aluminum top layer.

Vitreous Single Phase Coating - San Diego Porcelain was selected as the suppler for the vitreous single-phase coating. The coating, Solaramic S5-8A TM, was applied in slurry form to a coating thickness of $25 \mu \mathrm{m}$.

\section{Oxidation Testing of Coated Specimens}

AA coated samples were exposed at $1300^{\circ} \mathrm{F}$ and $1400^{\circ} \mathrm{F}$ in ambient air and at $1400^{\circ} \mathrm{F}$ in $10 \%$ humidified air. The weight of all oxidation test specimens was measured weekly and extra specimens were tested coincident with each test so that destructive analysis could be performed at key intervals.

The AA foil samples coated with the AS\&M TPG coating performed well in ambient air. After 1,000 hours of testing, both the $1300^{\circ} \mathrm{F}$ and $1400^{\circ} \mathrm{F}$ specimens displayed weight gains that were less than $0.20 \mathrm{mg} / \mathrm{cm}^{2}$. In contrast, the TPG coated specimens that were exposed to $1400^{\circ} \mathrm{F}$ in $10 \%$ humidified air exhibited a significantly poorer performance with an average weight gain of $1.24 \mathrm{mg} / \mathrm{cm}^{2}$ (Figure 4.2.4-1).

The AA foil samples coated with the Sermatech inorganic aluminide coating gained weight in a significantly different fashion with weight gains in ambient air after 1,000 hours of $1.20 \mathrm{mg} / \mathrm{cm}^{2}$ at $1300^{\circ} \mathrm{F}$ and $1.30 \mathrm{mg} / \mathrm{cm}^{2}$ at $1400^{\circ} \mathrm{F}$. The specimen that was exposed to $10 \%$ humidified air exhibited a weight gain of $15.83 \mathrm{mg} / \mathrm{cm}^{2}$ (Figure 4.2.4-2).

The AAA sample that was coated with the Solaramic S5-8A ${ }^{\mathrm{TM}}$ was exposed to $1400^{\circ} \mathrm{F}$ in $10 \%$ humidified air and was not tested in ambient air. The specimen oxidized rapidly and exposure testing was discontinued after 500 hours. The overall weight gain of the as-coated specimen was $5.65 \mathrm{mg} / \mathrm{cm}^{2}$ (Figure 4.2.4-3)

Metallographic cross-sections were prepared through all of the exposed specimens. The coated AA foil specimens that were exposed in ambient air displayed a compact oxide film with no appreciable thickness. In contrast, the specimens that were exposed to $10 \%$ humidified air displayed complete degradation of the coatings and extensive attack of the substrate. In the case 
of the specimen coated with Solaramic S5-8A $\mathrm{A}^{\mathrm{TM}}$, the specimens were friable, and upon handling, the samples crumbled and fell apart (Figure 4.2.4-4).

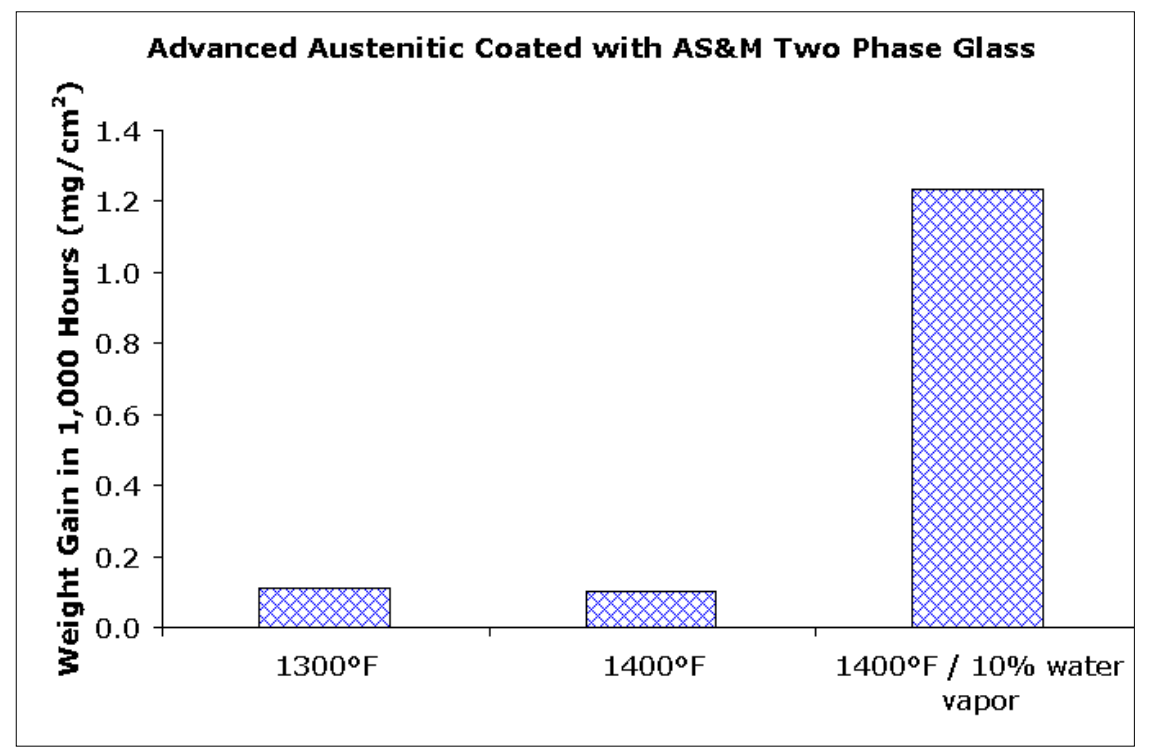

Figure 4.2.4-1. Total Weight Gain for AS\&M Two-phase Coated AA Foil After 1,000 Hours of Exposure

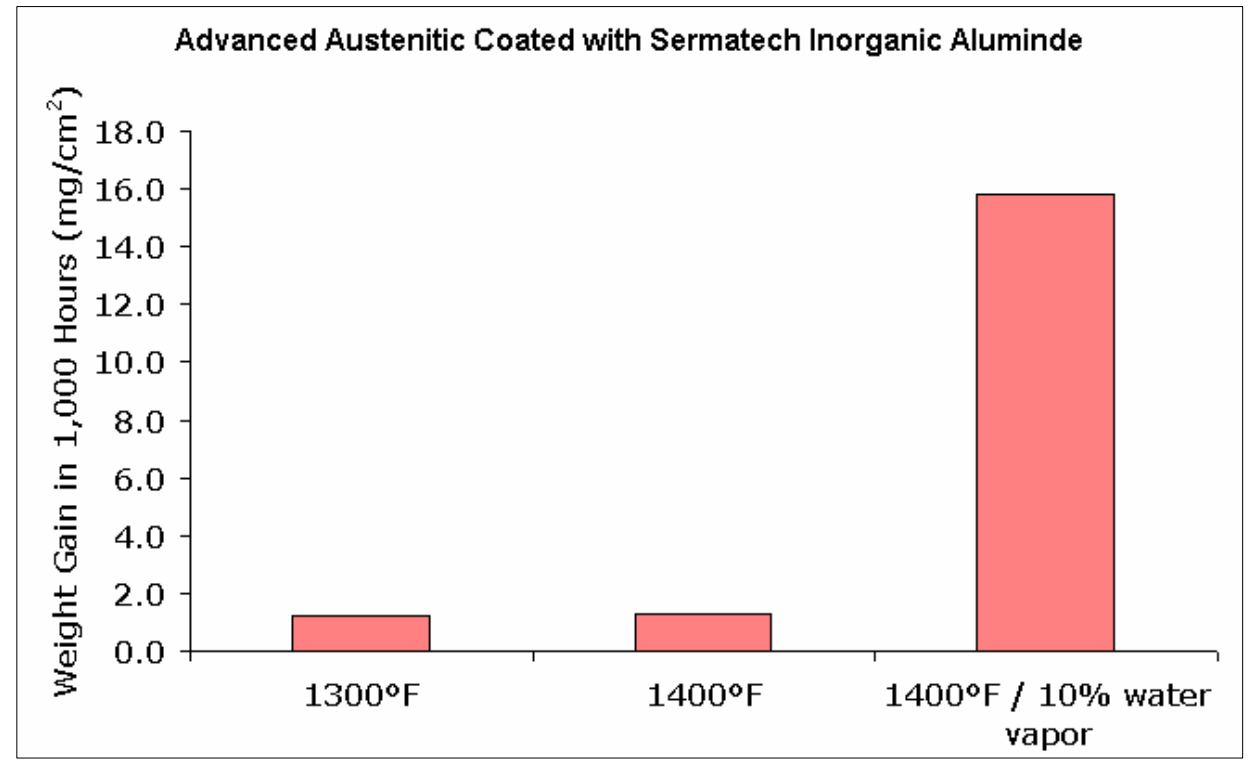

Figure 4.2.4-2. Total Weight Gain for Inorganic Aluminide (Sermatel 565) Coated AA Foil After 1,000 Hours of Exposure 


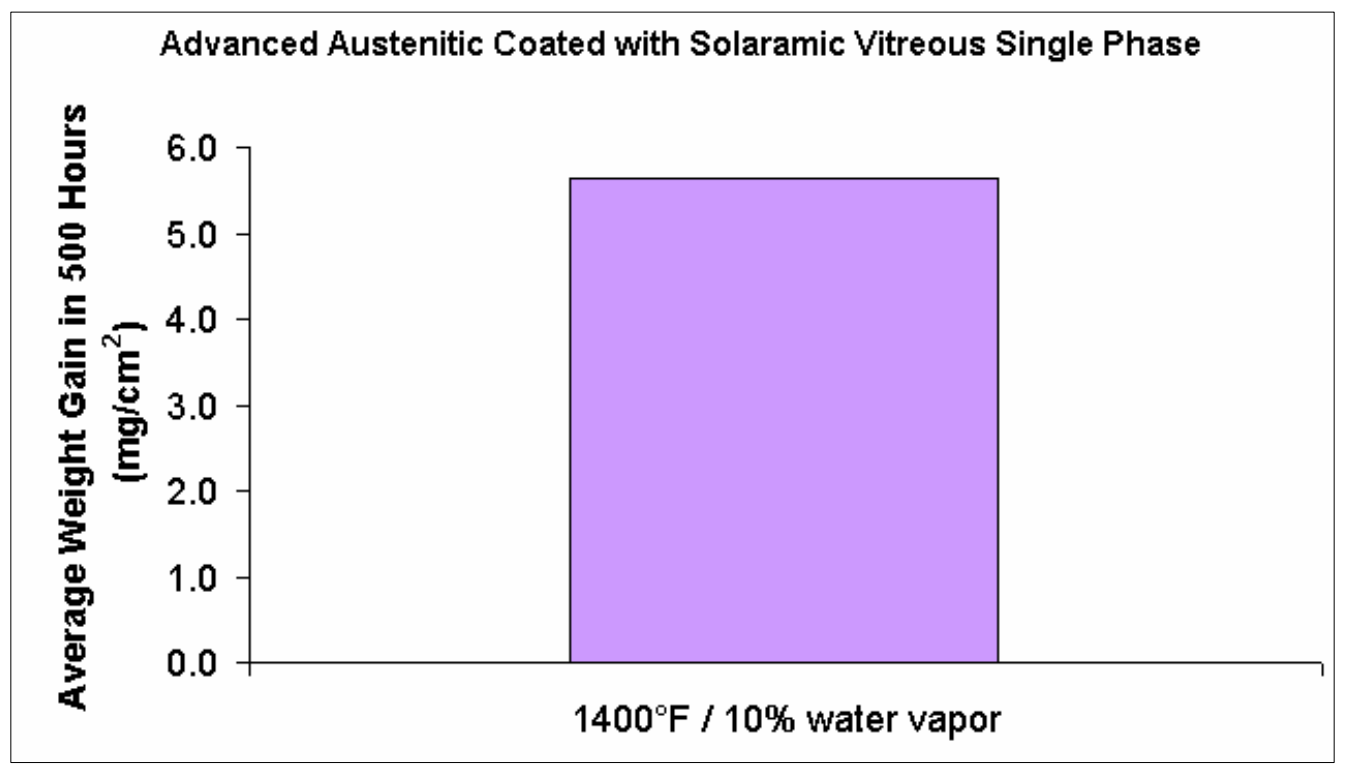

Figure 4.2.4-3. Average Weight-gain for Solaramic S5-8A ${ }^{\mathrm{TM}}$ Coated AA Foil After 500 Hours of Exposure

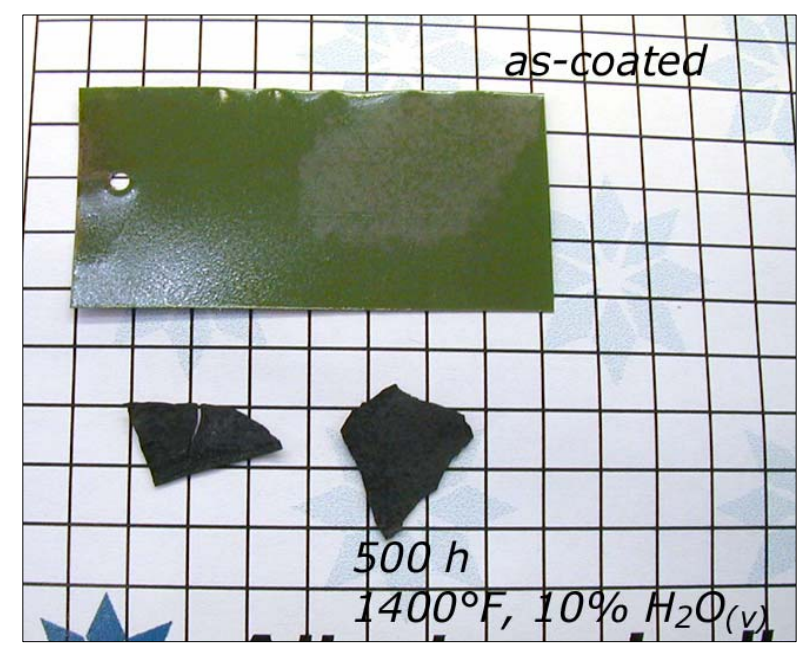

Figure 4.2.4-4. AA Foil with Solaramic S5-8A ${ }^{\mathrm{TM}}$ Coating Before (top) and After 500 Hours at $1400^{\circ} \mathrm{F}$ in $10 \%$ Humidified Air (bottom)

The test results of coated AA foil material at $1400^{\circ} \mathrm{F}$ in $10 \%$ humidified air were compared to the exposure test data of the uncoated AA foil. A comparative evaluation of the AS\&M two phase glass coating, the Sermatech inorganic aluminide coating, and the vitreous single phase coating revealed that the coating systems did not result in improved short term (500-1000 hours) oxidation resistance. After 500 hours of exposure at $1400^{\circ} \mathrm{F}$ in $10 \%$ humidified air, the uncoated AA foil had a weight gain of $0.10 \mathrm{mg} / \mathrm{cm}^{2}$. In comparison, the next best performer in $10 \%$ humidified air was the AA foil coated with the AS\&M TPG coating, which displayed a weight gain more than seven times greater at $0.73 \mathrm{mg} / \mathrm{cm}^{2}$ (Figure 4.2.4-5). In each instance, the coated specimens oxidized more readily than the uncoated substrate. Based on these findings, none of the coating systems displayed oxidation resistance properties suitable for recuperator service. A report on this task was incorporated into the WBS 1.3 Topical Report. 


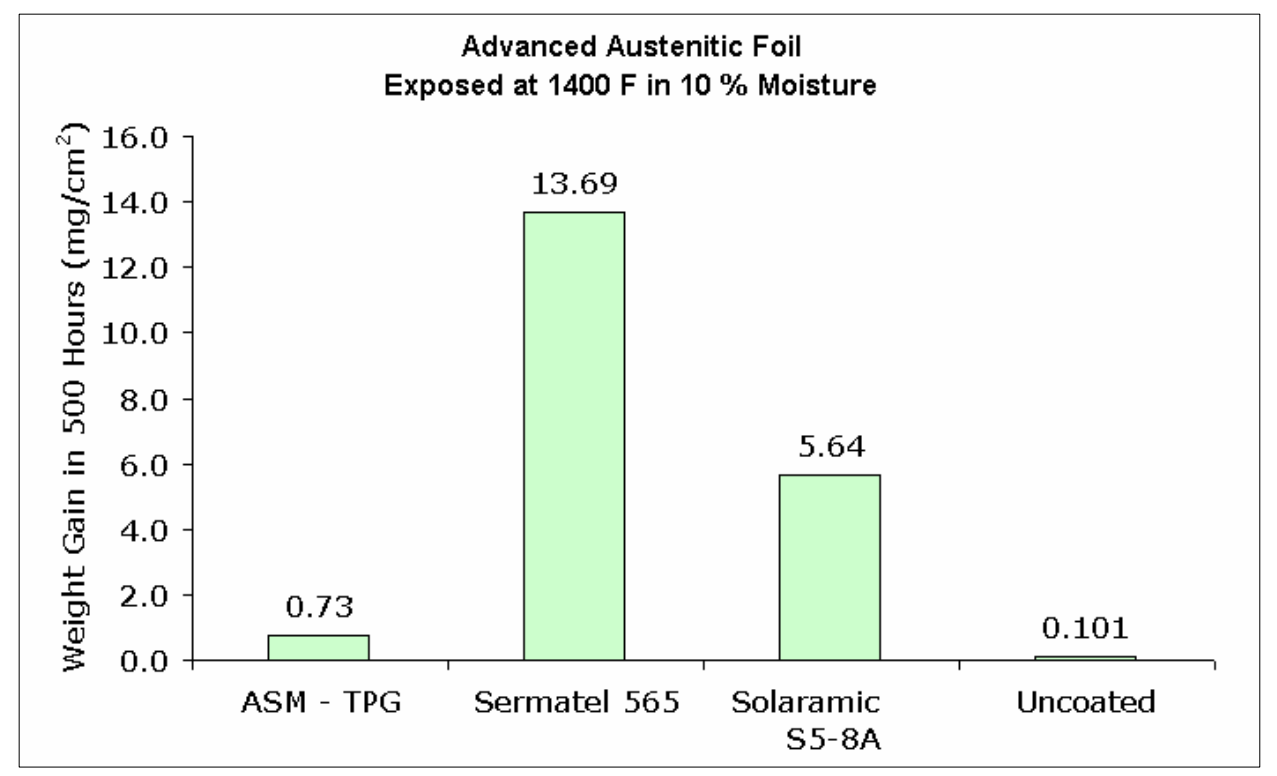

Figure 4.2.4-5. Weight Gained by Coated and Uncoated AA Foil

\subsubsection{Task 1.3.5 Dual Alloy Foil}

The intention of this task was to improve the oxidation resistance of the recuperator core material by developing a dual alloy foil that employed thin external layers of cladding to a Type $347 \mathrm{SS}$ core. The optimum cladding would have greater oxidation resistance than the core while the core would provide the creep resistance properties needed for service. These creep resistance properties of Type $347 \mathrm{SS}$ were to be improved as part of Task 1.3.2 of this program. (See Section 4.2.2). Besides displaying improved oxidation properties and being readily formable, the clad material would also need to be financially feasible and provide some advantage over other candidate monolithic foils.

\section{Cladding Fabrication}

An initial matrix of potential dual alloy clad systems was developed and the potential clad alloys included both Type 310 SS, Alloy 800, silica formers, Type 302B and Type 406, as well as an alumina former, DuraFoil (Table 4.2.5-1). The core material was projected to be creep resistant Type $347 \mathrm{SS}$; however, since this alloy was still in the development phase as part of this program, standard Type $347 \mathrm{SS}$ was used as the core material during testing. The cladding of a single side or both side of the Type 347 SS core was also considered since, in service, it was expected that the exhaust sides of the foil would experience a harsher oxidation environment than the gas side.

Engineering Materials Solutions was selected as the supplier to apply the cladding to the Type 347 SS core material. The feasibility study of the cladding process was performed on narrow, 4" widths of core and clad material in order to determine if the layers would bond together. The study was not intended to produce material with proper width or thickness for recuperator core assembly. It was determined that clad materials would be iron base and represent three types of oxide forming systems. Type 304 SS and Alloy 800 was selected as chromia formers, Type 406 and DuraFoil were selected as alumina formers, and Type 302B was selected as silica former (Figure 4.2.5-1). DuraFoil was not successfully bonded to the Type 347 SS foil core. 
Table 4.2.5-1. Composition of Potential Clad Foils

\begin{tabular}{|c|c|c|c|c|c|}
\hline \multirow[t]{3}{*}{ Element } & \multicolumn{5}{|c|}{ Nominal Compositions (Weight Percent) } \\
\hline & \multicolumn{2}{|c|}{ Chromia Formers } & \multicolumn{2}{|c|}{ Alumina Formers } & \multirow{2}{*}{$\begin{array}{c}\text { Silica Former } \\
\text { Type 302B }\end{array}$} \\
\hline & Type 310 SS & Alloy 800 & Type 406 & DuraFoil & \\
\hline Chromium & 25 & 21 & 13 & 20 & 19 \\
\hline Nickel & 12 & 32 & --- & --- & 8.5 \\
\hline Aluminum & --- & --- & 4.5 & 6 & --- \\
\hline Manganese & 1.5 & 1.0 & --- & --- & --- \\
\hline Silicon & --- & --- & --- & --- & 2.5 \\
\hline Cerium + Lanthanum & --- & --- & --- & 0.05 & --- \\
\hline Iron & Balance & Balance & Balance & Balance & Balance \\
\hline
\end{tabular}

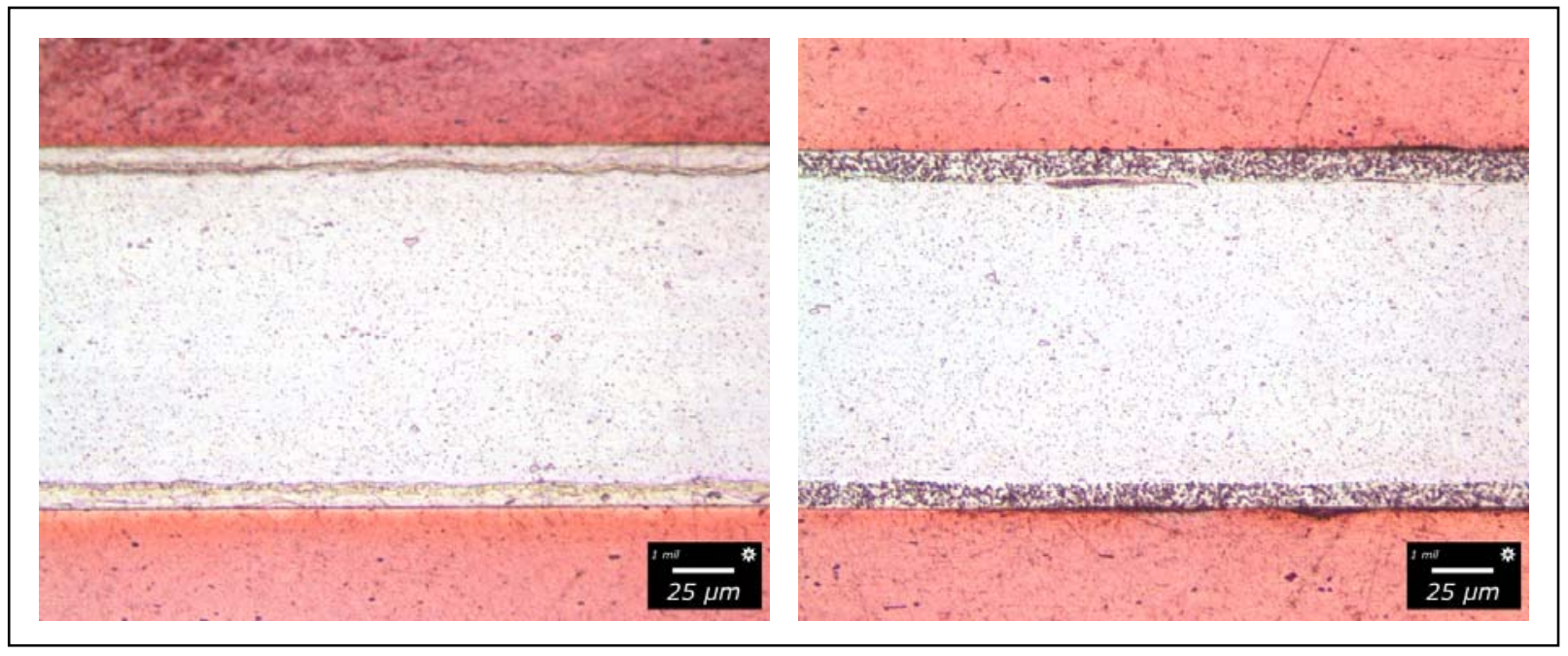

Figure 4.2.5-1. Photomicrograph of Cross-section Through Fabricated Dual Clad Assemblies Showing Alloy 800 (left) and Type 310 SS Foil (right) Successfully Bonded to Type 347 SS Core Material

\section{Oxidation Testing}

Samples of each of the five potential alloys were oxidation tested. Based on the timing and ability to apply the cladding, test specimens varied in section thickness, with some of the proposed clad material being testing as monolithic specimens and others being tested bonded to Type $347 \mathrm{SS}$. Testing was performed at $1300^{\circ} \mathrm{F}$ in $7 \%$ and $10 \%$ humidified air as well as at $1400^{\circ} \mathrm{F}$ in $7 \%$ humidified air. Specimens were removed from the furnace on a weekly basis and weighed and where applicable, the resulting test data were normalized to reflect weight gain on both sides of the specimen.

Comparative oxidation test data at $1400^{\circ} \mathrm{F}$ in $7 \%$ humidified air indicated the five candidate clad materials displayed weight gains ranging from 0.42 to $0.98 \mathrm{mg} / \mathrm{cm}^{2}$ after 2,000 hours exposure. In each instance, the weight gain of the clad materials was less than that of Type 347 foil, which displayed a weight gain of $2.76 \mathrm{mg} / \mathrm{cm}^{2}$ after the same exposure conditions. However, the clad material did not perform as well as the AA foil material, which displayed a weight gain of 0.30 $\mathrm{mg} / \mathrm{cm}^{2}$ after being exposed to similar conditions for 2,000 hours (Figure 4.2.5-2). 


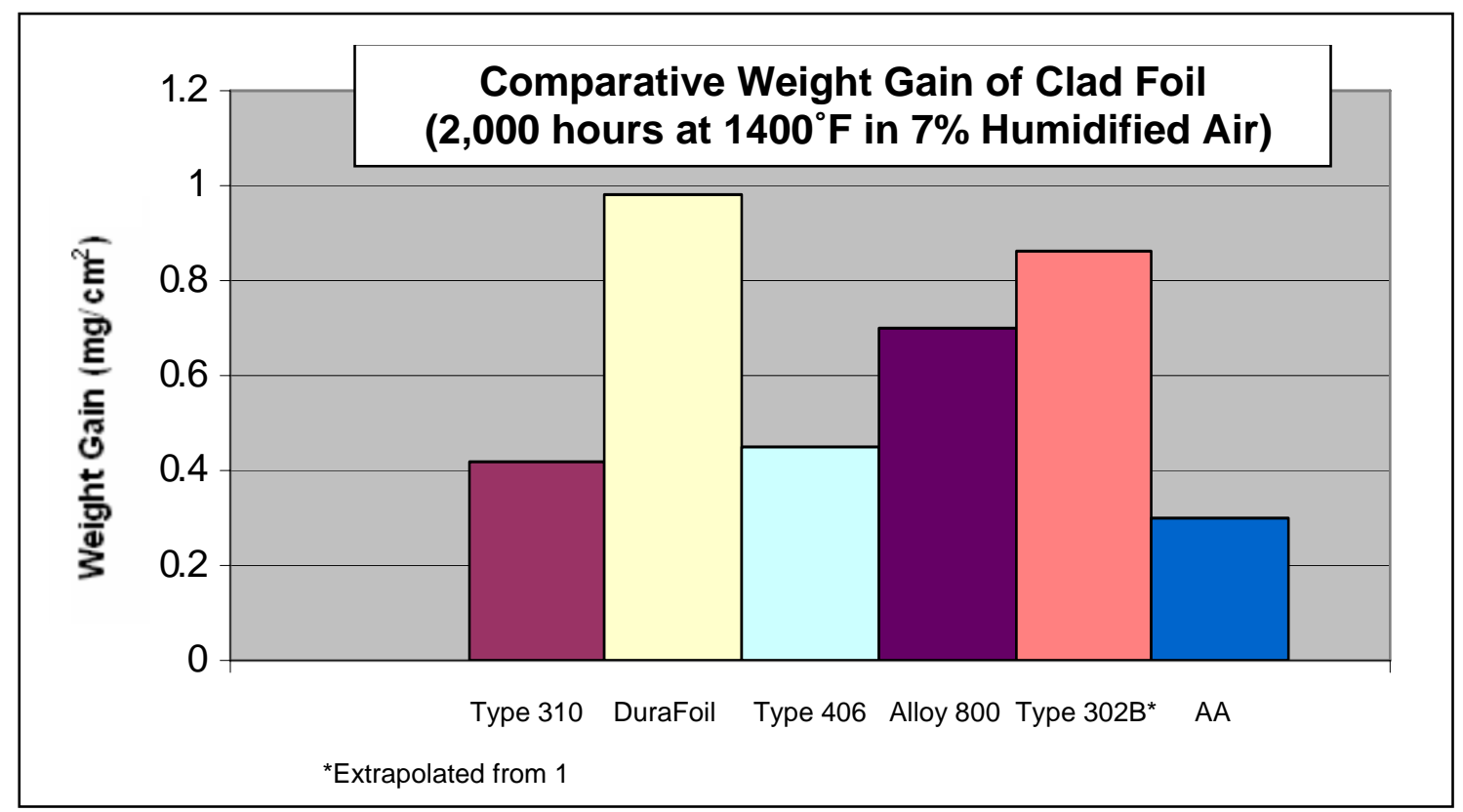

Figure 4.2.5-2. Weight Gain of the Potential Cladding Materials Compared with AA Foil after 2,000 Hours of Exposure at $1400^{\circ} \mathrm{F}$ in $7 \%$ Humid Air

Microstructural analyses of a representative metallurgical section through the Type 310 SS clad foil after exposure to $1300^{\circ} \mathrm{F}$ in $7 \%$ humidified air for 5,000 hours revealed evidence of considerable chromium diffusion from the clad material into the Type 347 SS substrate. Porosity at the cladding to substrate was evident, but appeared to be a sample preparation artifact. The oxide on the outer surface of the cladding had a uniform thickness of approximately $4 \mu \mathrm{m}$ and consisted of two distinct layers. The layer on the outer surface made up most of the thickness of the oxide and was rich in manganese and chromium. Voids were evident at the cladding to substrate interface. The sub-scale oxide layer exhibited an irregular interface with the substrate and consisted primarily of chromium (Figure 4.2.5-3).

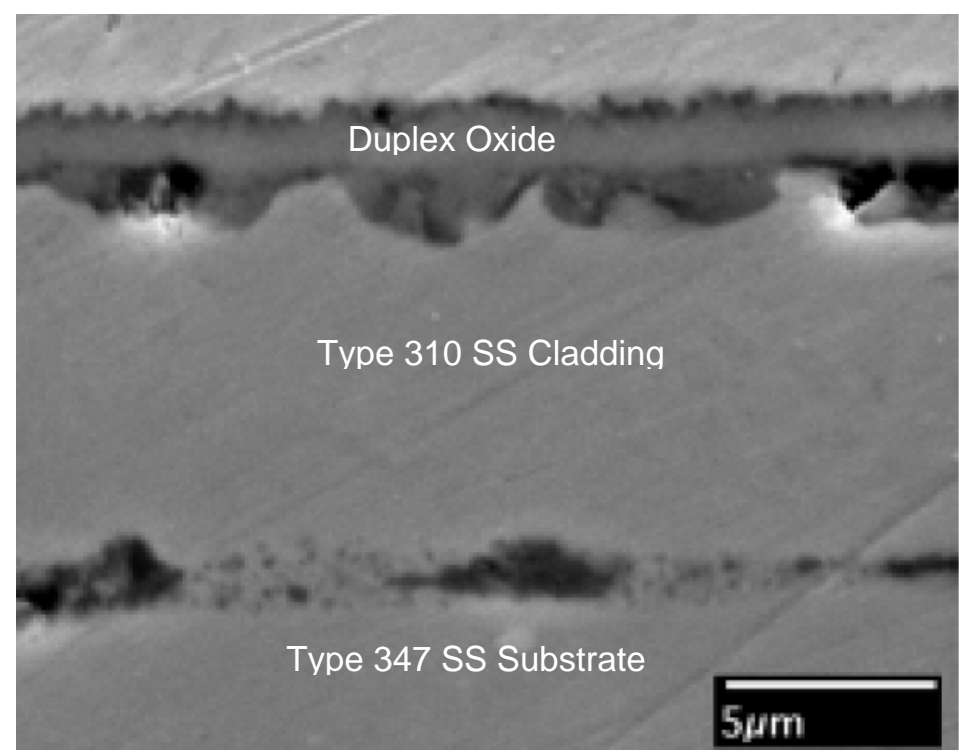

Figure 4.2.5-3. SEM Photomicrograph of the surface region on a Type 347 SS Clad with Type 310 SS that was exposed at $1300^{\circ} \mathrm{F}$ in $7 \%$ humidified air for 5,000 hours 


\section{Creep Testing}

Creep testing of representative Type 347 SS foil samples, one clad with Type 310 SS and the other clad with Alloy 800 was performed at $1350^{\circ} \mathrm{F}$ and $7 \mathrm{ksi}$. Since the core material was standard Type 347 foil, the creep strength had been well documented. Accordingly, the creep testing was performed primarily to determine if separation at the clad to substrate interface might occur.

Creep test result indicated that the times to $1 \%$ creep were 471 hours for the Alloy 800 clad specimens and 291 hours for the Type 310 SS clad specimen. These times to 1\% creep were typical of standard Type 347 SS foil. Examination of the creep specimens subsequent to testing revealed no evidence of separation or break down between the cladding and the substrate.

\section{Selection for Recuperator Application}

As determined by exposure testing, all of the clad materials provided an improvement in the oxidation protection for the core material. However, this improvement did not provide any advantage over the monolithic AA foil that was being developed as part of this program (Task 1.3.3, see section 4.2.3). Accordingly, with the challenges and potential economic issues related to cladding and then forming large sheets of foil, it was deem unfeasible to pursue further work with the clad materials. A report on this task was incorporated into the WBS 1.3 Topical Report.

\subsubsection{Task 1.3.6 Super-Alloy Foil}

Another approach taken to find a material that met the program goals of a recuperator operating temperature at $1350^{\circ} \mathrm{F}$ with a life of 45,000 hours was to select and characterize a nickel-based superalloy. This task primarily involved alloy characterization and was not intended to explore alloy development. A nickel-based alloy would presumably be more expensive, but would likely provide greater creep and oxidation resistance. Early in the task, Alloy 625 and Alloy X were selected as potential candidate materials, although the primary focus was on Alloy 625, because of it previous use as a recuperator alloy. Composition analyses of foil samples from each alloy were performed at the initiation of the task (Table 4.2.6-1).

Table 4.2.6-1. Composition of Candidate Superalloy Foils

\begin{tabular}{|l||c|c|}
\hline Element & Alloy X & Alloy 625 \\
\hline \hline Chromium & 22.8 & 20.8 \\
\hline Nickel & Balance & Balance \\
\hline Manganese & 0.6 & 0.03 \\
\hline Molybdenum & 9.0 & 8.3 \\
\hline Silicon & 0.2 & 0.13 \\
\hline Titanium & --- & 0.17 \\
\hline Cobalt & 1.1 & --- \\
\hline Tungsten & 0.5 & --- \\
\hline Aluminum & --- & 0.21 \\
\hline Niobium & 0.08 & 3.8 \\
\hline Iron & 18.8 & 4.4 \\
\hline
\end{tabular}




\section{Oxidation Testing}

Alloy 625 foil was tested at $1300^{\circ} \mathrm{F}, 1400^{\circ} \mathrm{F}$, and $1500^{\circ} \mathrm{F}$ in ambient air, $7 \%$ humidified air, and $10 \%$ humidified air while Alloy $\mathrm{X}$ foil was tested at $1300^{\circ} \mathrm{F}$ and $1400^{\circ} \mathrm{F}$ in ambient air and at $1500^{\circ} \mathrm{F}$ in $7 \%$ humidified air. The same test methodology that was used to test other materials as part of this program was also used for testing these materials with weight gain being measured on a weekly basis.

After nearly 9,300 hours of exposure to ambient conditions at $1300^{\circ} \mathrm{F}$ the Alloy $\mathrm{X}$ foil specimens displayed an average weight gain of $0.22 \mathrm{mg} / \mathrm{cm}^{2}$ and the Alloy 625 foil specimens displayed an average weight gain of $0.16 \mathrm{mg} / \mathrm{cm}^{2}$. Exposure of both materials to ambient conditions at $1400^{\circ} \mathrm{F}$ for nearly 9,300 hours resulted in a greater weight gain with the Alloy $\mathrm{X}$ foil specimens displaying an average weight gain of $0.80 \mathrm{mg} / \mathrm{cm}^{2}$ and the Alloy 625 specimens displaying an average weight gain of $0.52 \mathrm{mg} / \mathrm{cm}^{2}$. Upon testing both of these alloys in humidified air, it became evident that the oxidation process had changed for the Alloy 625 material. After 10,000 at $1400^{\circ} \mathrm{F}$, the Alloy X foil displayed gradual parametric weight gain to $0.69 \mathrm{mg} / \mathrm{cm}^{2}$; however, in contrast, the weight gain of the Alloy 625 specimen peaked after 2,200 hours at $0.32 \mathrm{mg} / \mathrm{cm}^{2}$ and then steadily decreased with a final weight of $0.18 \mathrm{mg} / \mathrm{cm}^{2}$. This decreasing weight gain had not been displayed during any of the foil oxidation testing preformed as part of this program (Figure 4.2.6-1). Close inspection of the specimen and crucibles that held the Alloy 625 specimen revealed no evidence of spallation.

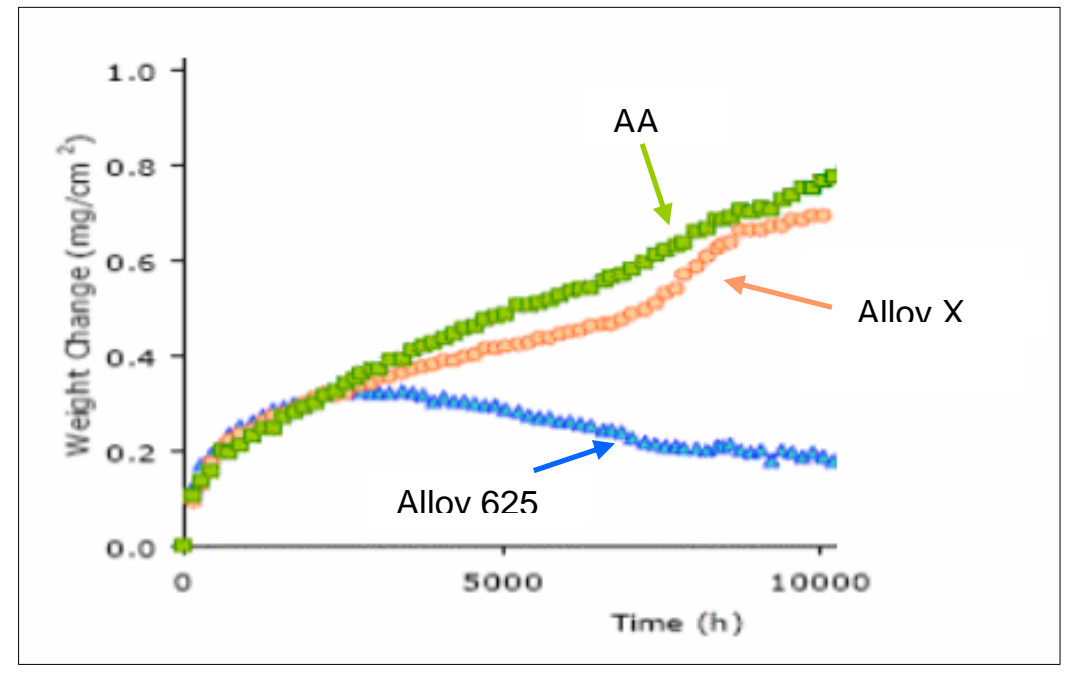

Figure 4.2.6-1. Weight Gain of Alloy 625, Alloy $X$ and AA Foil exposed for 10,000 Hours at $1400^{\circ} \mathrm{F}$ in $7 \%$ Humidified Air

Subsequent exposure testing of Alloy 625 foil at $1300^{\circ} \mathrm{F}$ and $1500^{\circ} \mathrm{F}$ in $7 \%$ and $10 \%$ humidified air also produced the same diminishing weight gain. Metallurgical sections through the Alloy 625 specimens that were exposed to $1300^{\circ} \mathrm{F}, 1400^{\circ} \mathrm{F}$, and $1500^{\circ} \mathrm{F}$ for prolonged periods in humidified air were prepared and evaluated. The foils displayed a thin $(2-4 \mu \mathrm{m})$ oxide scale that composition analyses indicated consisted essentially of pure chromium oxide. Extensive subscale voids were present at the oxide to substrate interface and internal oxide particles were present along the grain boundaries (Figure 4.2.6-2). Comparative residual compositional profiles, as measured using micro-chemical analysis techniques, were performed on specimen 
exposed to ambient air and humidified air for 10,000 hours at $1400^{\circ} \mathrm{F}$. Analytical results indicated that moisture increased both the depth and level of chromium depletion in the substrate (Figure 4.2.6-3). Further analysis indicated that this type of behavior was consistent with all the Alloy 625 specimens exposed to humidified air and that the Alloy X sample displayed less of this type of behavior. Based on this evidence, the decrease in weight gain for the Alloy 625 foils was attributed to scale thinning due to the evaporative loss of chromium

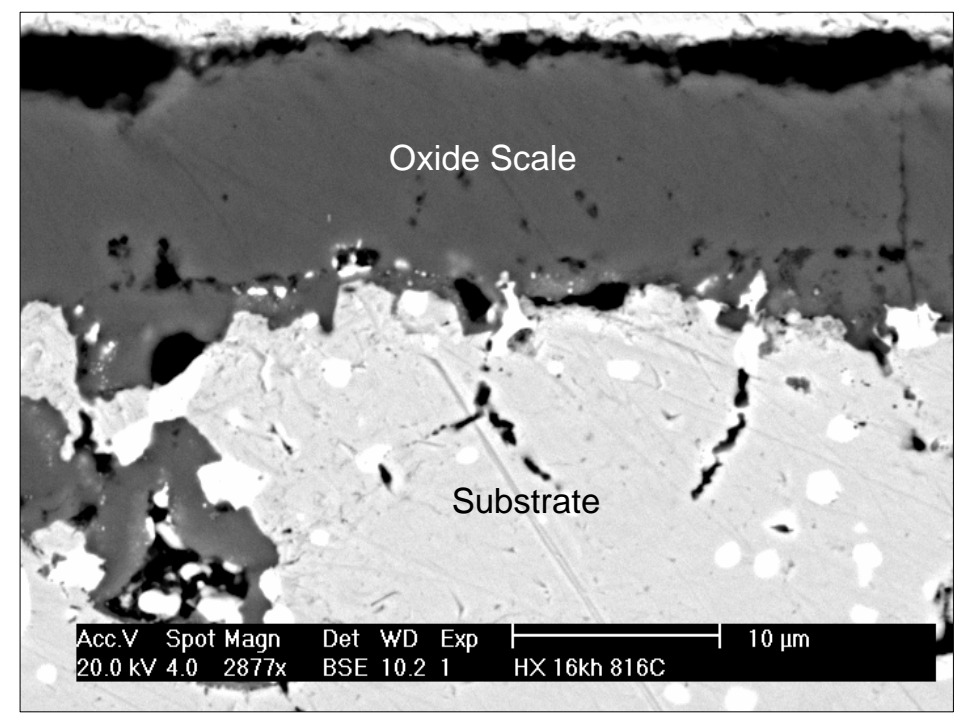

Figure 4.2.6-2. SEM Photomicrograph of Cross-section through an Alloy 625 Specimen that was Exposed for 15,865 Hours at $1500^{\circ} \mathrm{F}$ in $7 \%$ Humidified Air

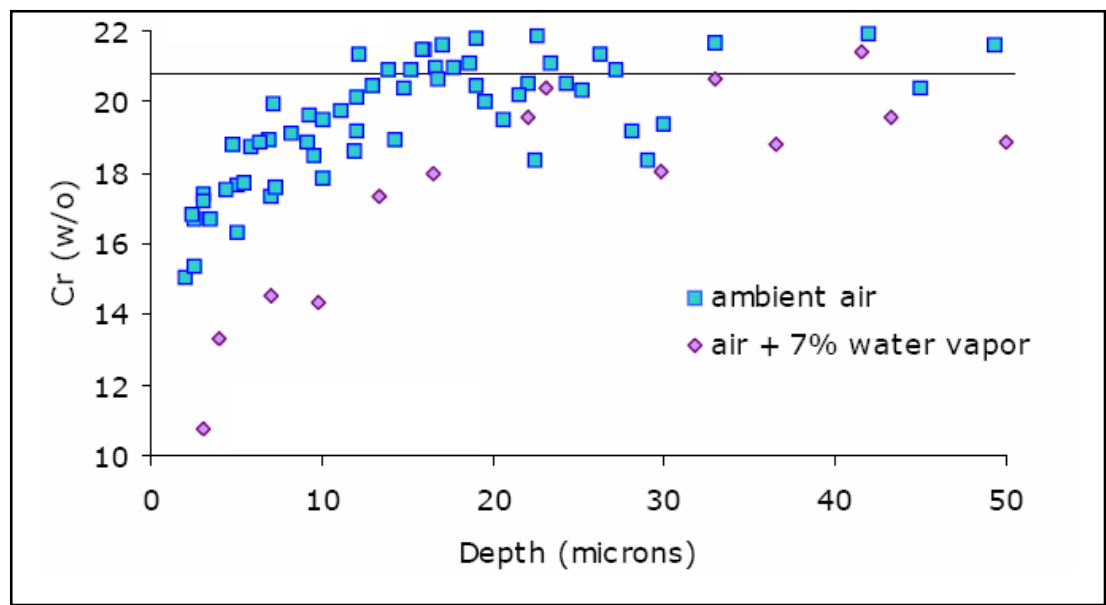

Figure 4.2.6-3. Residual Chromium in Alloy 625 as a Function of Depth after 8,000 Hours (7\% Humidified Air) and 10,000 Hours (Ambient) at $1400^{\circ} \mathrm{F}$

Based on the positive exposure results and the recuperator experience of Alloy 625 over Alloy X, Alloy 625 was selected as the prominent material for further characterization. Upon completion of this exposure testing, a calculated curve was fitted to the data and a limited lifetime phenomenological model was developed so that time at maximum exposure temperature for a prescribed duration could be identified. Due to the influence of chromium evaporation on the 
oxidation kinetics, fitting the data was more of a challenge than it was for modeling the iron based recuperator foil materials (Figure 4.2.6-4). However, based on the oxidation model, the predicted operating temperature for the program life goal of 45,000 was well above the program temperature goal of $1350^{\circ} \mathrm{F}$.

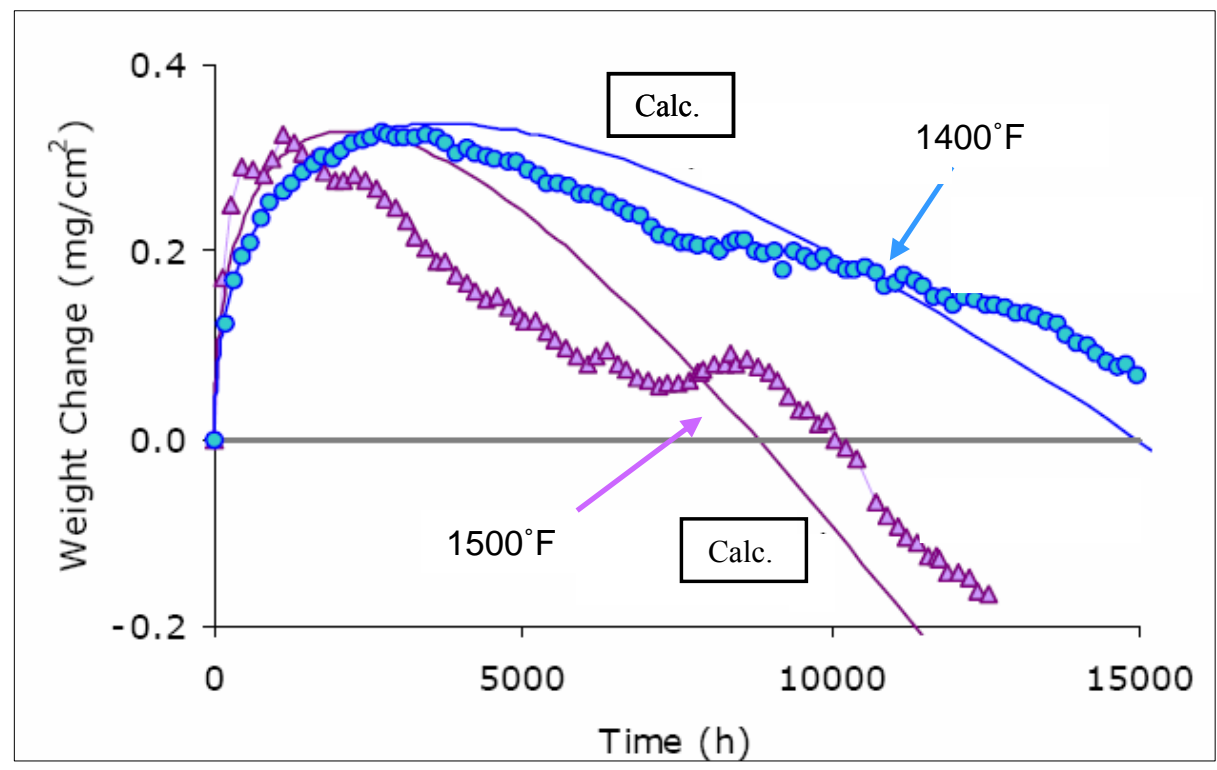

Figure 4.2.6-4. Experimentally Measured and Experimentally Calculated Model for Alloy 625 Exposed at $1400^{\circ} \mathrm{F}$ and $1500^{\circ} \mathrm{F}$ in $7 \%$ Humidified Air

\section{Creep Testing}

Creep testing of Alloy 625 foil was primarily focused on characterization of standard 0.004 " thick foil with a grain size of ASTM \#8.5 to 11.0. Testing of alloy 625 foil specimens indicated that, as expected, the creep properties were significantly better than those of Type 347 SS or AA foil with both higher test temperatures and stresses needed in order to complete creep testing in a reasonable time frame. Data from this testing was then used to create a Larson-Miller curve for predicting $1 \%$ creep behavior which was compared to that of Type 347 and AA foil. The Larson-Miller curves indicated that at the higher stresses, the Alloy 625 had significantly higher creep strength than the AA foil, however, at the lower stresses, the AA and Alloy 625 foil displayed similar creep resistance. Accordingly, for an operating stress of $7 \mathrm{ksi}$. at $1350^{\circ} \mathrm{F}$, the time to $1 \%$ creep was also estimated to be greater than 5,800 hours (Figure 4.2.6-5).

\section{Selection for Recuperator Application}

As with the AA foil material, several sub-size aircells were manufactured using Alloy 625. The manufacturing process consisted of folding (corrugating the foil), pressing, and shearing the folded structure to the proper size, and the welding of bar material around the surface of the foil to provide structural integrity. Non-destructive and destructive metallurgical analysis indicated that the Alloy 625 foil was suitable to be processed for recuperator components. Given the excellent performance of the Alloy 625 foil in fabrication, oxidation testing and creep testing, further use of this alloy as a recuperator core material was recommended. A report on this task was incorporated into the WBS 1.3 Topical Report. 


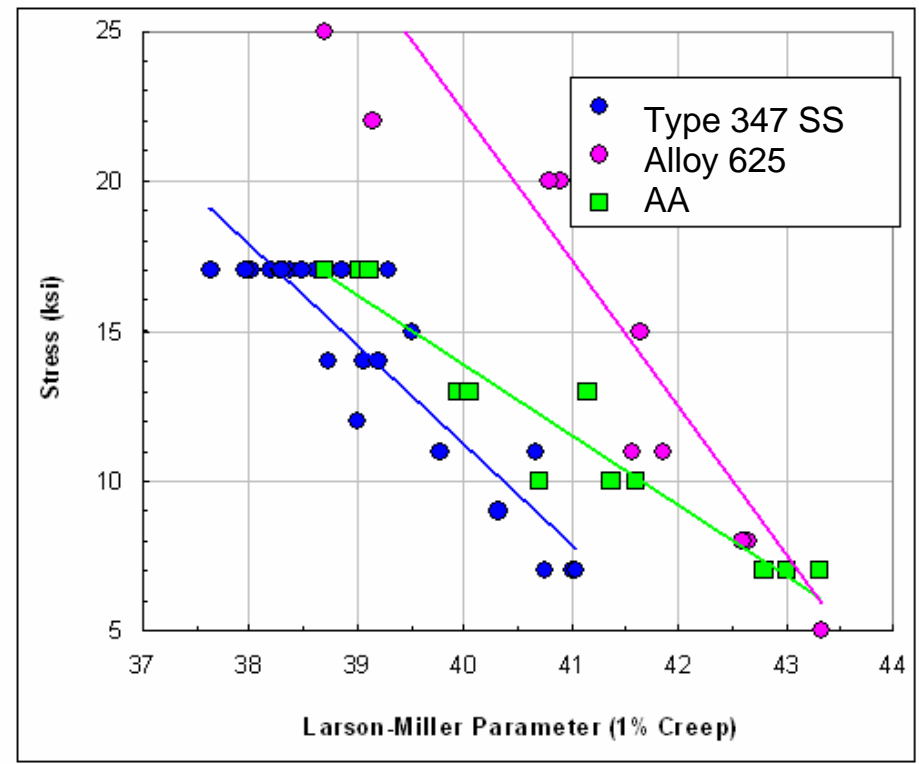

Figure 4.2.6-5. Comparative 1\% Creep Larson-Miller Curve for Alloy 625, Type 347 SS and AA Foil

\subsection{TASK 1.4 RECUPERATOR FABRICATION DEVELOPMENT}

Statement of work: WBS 1.4 Recuperator Fabrication Development - The various aspects of the Solar PSR fabrication process that have a major effect on the performance, production volumes, and cost will be evaluated, and improvements recommended and implemented. This subtask will be primarily conducted by Solar with the assistance of subcontract expertise where needed.

Effort that was underway within WBS 1.4 either was stopped or was shifted to Solar-funded projects in 2002. Reports were written to document the effort and accomplishments of the various sub-projects. In 2003, as more funding became available, a project was defined within the scope of task 1.4 and started to conduct a systematic analysis and improvement of the primary sheet fin folding process using Taguchi methodology. The aim of this task was to improve the process so that the drawing requirements for primary recuperator sheet can be consistently met, scrap eliminated, and the time needed for subsequent manufacturing reduced. This will improve recuperator performance and reduce the cost of this critical microturbine system component.

\subsubsection{Task 1.4.1 Primary Sheet Folded S tock Monitoring}

The goal of this task is to design and test a functional in-process quality monitoring system that is closed-looped with machine controls. The quote from J.H. Benedict was received and a purchase requisition was written on May 31, 2001. Purchasing obtained approval from DOE to proceed with J.H. Benedict on this scope of work. 
The initial scope of work consisted of five phases to be completed by August 24, 2001:

- Fin folder equipment setup

- Identify and prioritize process parameters

- Determine measurement methodology

- Determine data collection methodology

- Develop report generation format

The second scope of work consisted of four phases to be completed by November 30, 2001:

- Procure measuring and reporting equipment

- Install and integrate measuring and reporting equipment

- Collect data and generate reports

- Identify and quantify cause and effect relationships

The third scope of work consisted of three phases to be completed by March 5, 2002:

- Design a process control system

- Build and implement a process control system

- Monitor the results

This phase of work depended on the results of the first two scopes, which determined what process settings were needed to be controlled and how much adjustment was required.

All the equipment necessary to monitor the quality variables of the primary sheet was received, integrated, tested and installed on the fin folder. Experimentation started on May 20, 2002. Testing was halted on May 31, 2002 as part of the program refocus. The range of control parameters was established, but the inter-relationships were not determined. Results were included in the Task 1.4 Topical Report.

\subsubsection{Task 1.4.2 Improving Primary Sheet Parameters}

The goal of this task is to develop a cleanliness specification and monitoring system for folded primary sheet stock. A meeting was held at TurboFab with Jack Keck of Savante, Inc. to discuss their interest in proceeding with the development of a cleanliness monitoring system for primary surface folded stock. Savante was interested and provided a proposal to Solar by December 31, 2001.

The build of test cores started on March 6, 2002 and was completed on April 3, 2002. The testing started on April 15, 2002 and was completed on May 10, 2002. This project was completed on May 17, 2002. Results were included in the Task 1.4 Topical Report.

\subsubsection{Task 1.4.3 Pressure Drop Reduction}

The goal of this task was to change the recuperator primary sheet design to reduced pressure drop by $15 \%$. The scope of work was defined and the request for quotation sent out on September 15, 2001. The work included: 
- Review pressure drop data from Honeywell cores.

- Make 4" square crush die to simulate transition area of primary sheet with six different ramp angles.

- Analyze digital photos of six different transition ramp angles and select one with minimum blockage.

- Modify primary sheet crush die with best transition ramp.

- Build Honeywell style recuperator with improved ramp angle transition.

- Test improved Honeywell core and compare to previous data.

A 4" square crush die to simulate transition area of primary sheet with six different ramp angles was completed and six sets of sample sheets were produced for evaluation.

It was not possible to determine minimum blockage by photographing and digitizing the six samples. It became apparent that flow models would be required. Table 4.3.3-1 lists the test cores that were to be evaluated.

Table 4.3.3-1. Test Cores to Be Evaluated.

\begin{tabular}{|c|c|c|c|}
\hline $\begin{array}{c}\text { Test Core } \\
\text { Number }\end{array}$ & $\begin{array}{c}\text { Gas Bar to } \\
\text { Sheet Weld }\end{array}$ & $\begin{array}{c}\text { Fin Fold Blade } \\
\text { Configuration }\end{array}$ & Crush Zone \\
\hline 1 & Uncoined & Constant thickness & Bias crush \\
\hline 2 & Coined & Constant thickness & Bias crush \\
\hline 3 & Coined & Continuous radius & Bias crush \\
\hline 4 & Coined & Constant thickness & Stagger crush \\
\hline $\begin{array}{c}\text { Section of core } \\
17\end{array}$ & Coined & Constant thickness & Bias crush \\
\hline
\end{tabular}

- Modify primary sheet crush die with the "B" sheet counterflow area 0.095 " narrower than the "A" sheet.

- Pressure drop flow rig for a 7.0" section (38 cells) of Mercury core was completed.

- If the continuous radius blade showed improved pressure drop, a creep core to evaluate the effects of creep on the continuous radius folded material at temperature would be made and evaluated.

The five pressure-drop cores were tested and the data was not as anticipated with the airside pressure drop being too high. It was determined that the glue used to hold the air manifolds in place was causing considerable blockage. The cores were baked in a vacuum furnace for one hour at $1300^{\circ} \mathrm{F}$ to burn out any residual glue. Retest of the five cores was completed in June 2002.

Results were included in the Task 1.4 Topical Report.

\subsubsection{Task 1.4.4 Automation}

\subsubsection{Task 1.4.4.1 Automation - Vision Welding}

The goal of this work was to extend the vision weld capability used on circular recuperators to rectangular recuperators. The scope of work was defined and the purchase order was sent out on 
September 25, 2001. The current manufacturing process was reviewed with TurboFab on November 13, 2001. The project was intended to prove the following concepts of M-cell core assembly:

- Develop cell coining operation - Design of coining die is complete and in manufacture. Develop core assembly (stacking of the air cells).

- Applying the butterpass welds to the air-in and air-out areas using the Servo vision system to track the edge of the core.

- Develop butterpass weld preparation.

- Utilize the vision system to analyze the weld joints at the air-in and air-out areas

- Develop the robotic welding of adjacent air-in or air-out cells.

Objectives:

- Develop and validate several manufacturing processes for the production of M-cell core assemblies.

- Document \& evaluate results in order to ensure conformance to print specifications.

- Minimize manual intervention required to produce M-cell core assemblies.

- Assemble and weld core assembly in 10 hours or less.

Sub-tasks:

- Design \& fabricate M-cell coining die.

- Design \& Fabricate M-cell cartridge fixture.

- Implement modifications to Mercury Servo/PAW welding cell.

- Assemble Mercury Servo/PAW welding cell.

- Integrate cold wire feed unit into Mercury Servo/PAW welding cell.

- Evaluate butterpass welding techniques.

- Develop a butterpass prep process.

- Optimize cell-to-cell joint weld process.

- Fabricate five M-cell core assemblies.

- Document results of work on project.

The optimization of cell-to-cell welding techniques progressed. One complete core was used for both butter pass and cell welding development. A second core was manufactured using the process prescribed by TurboFab. Some preliminary testing on machining/grinding the butter pass was begun. The design of the butter pass prep system using the F200 robot was based on the results of this preliminary testing. TurboFab shipped 400 air cells on March 27, 2002. These cells were of the correct air bar configuration and were welded along with the original five (5) cores. The cold wire feed remained to be integrated into this process.

Work on this task was stopped on May 17, 2002 as part of the program refocus. Results were included in the Task 1.4 Topical Report.

\subsubsection{Task 1.4.4.2 Automation - Robotic Duct Welding}

The goal of this work was to develop automatic recuperator ducting welding process technology. The scope of work was to prove the following concepts of rectangular recuperator assembly: 
- Develop recuperator air duct locate $\&$ tack weld fixture

- Develop recuperator end beams \& TBRS assembly process.

- Develop gas duct location and tack weld fixture.

- Develop gas duct trunion weld fixture.

- Develop air duct \& gas duct welding process.

- Welding cell setup \& systems integration.

- Manufacture and evaluate five recuperator assemblies.

- Document development work on this project.

Scope of work was defined and a purchase order was sent out on September 25, 2001. Work on this task was to commence after progress was made on the core vision-welding task.

\section{Objectives:}

- Develop and validate manufacturing processes for the production of M-cell recuperator assemblies.

- Document \& evaluate results in order to ensure conformance to print specifications.

- Minimize manual intervention required to produce M-cell recuperator assemblies.

- Assemble and weld recuperator ducts to core in 6 hours or less.

The optimization of cell-to-cell welding techniques was completed to the point of integrating the cold wire feed. One complete core was used for both butter pass and cell welding development. A second core was manufactured using the process prescribed by TurboFab. Some preliminary testing on machining/grinding the butter pass was accomplished. The design of the butter pass prep system using the F200 robot was based on the results of this preliminary testing. TurboFab shipped 400 air cells on March 27, 2002. Those cells had the correct air bar configuration and were to be welded along with the original five (5) cores.

Work on this task was stopped on May 31, 2002 as part of the program redirection.

\subsubsection{Task 1.4.4.3 - Automation - Laser Welding}

The purpose of this task was to investigate the benefit of Nuvonyx diode laser welding with a goal to increase the welding speed of primary foil to header bar and to reduce recuperator labor $10 \%$ to $15 \%$. The scope of work was defined for J.H. Benedict to produce welding coupons to be welded by Caterpillar Technical Center using a Nuvonyx diode laser. If weld coupons were satisfactory, J.H. Benedict would integrate diode laser on our existing robotic weld systems.

The scope of work was defined for J.H. Benedict and their purchase order was revised on November 6, 2001 to include this work. J.H. Benedict worked with the Caterpillar Technical Center on diode laser weld development. Solar completed the metallurgical evaluations of weld samples. Results were included in the Task 1.4 Topical Report.

\subsubsection{Task 1.4.5 Fin Folder Design of Experiment (DoE)}

The fabrication of primary surface recuperators for gas turbines and microturbines is highly complex involving a multitude of process variables, which are highly interactive. After over 25 years of improvements to recuperator manufacture at Solar Turbines Incorporated, fabrication of 
the recuperator primary sheet is still prone to scatter of output measures with drawing requirements caused by variations in raw foil properties and changes in environmental conditions. This project performed systematic analysis and improvement of the primary sheet fin folding process using Taguchi methodology. The approach was to break the overall system into subsystems, analyze each subsystem using computer simulation for fin folding and then to analyze the complete system in actual use. The aim was to improve the fabrication process so that multiple drawing requirements for primary recuperator sheet are met with less variation, scrap is eliminated, and the time needed for subsequent manufacturing steps is reduced. An improved system is more robust, meaning variability in the primary sheet is minimized and all drawing requirements are consistently met. Improvement is measured by calculating the ratio of desired output to undesired (noise) output, i.e. the signal to noise $(\mathrm{S} / \mathrm{N})$ ratio. More consistent primary sheet will improve overall system performance and reduce the cost of a critical gas turbine system component. A secondary objective was to increase the durability of the finfolding blades.

The project team recognized early that folding primary sheet was a complex process and would be difficult to analyze all at once. The fin folding equipment with which primary sheet material was folded at the JH Benedict Company is shown in Fig. 4.4.5-1. To facilitate analysis, the process was broken down into the following subsystems:

De-Reeler - Holds the spool of flat foil stock and feeds foil as needed into the lubrication bath. This subsystem was analyzed and determined not to be a factor in primary sheet variability.

Lubricant Subsystem - Provides a thin coating of lubricant to both sides of the foil to reduce friction during the folding process. Analysis of this system led to a study of friction coefficients for various lubricants and folding blade coatings.

Caterpillar Technical Center completed testing friction coefficients using pins rubbed against foil flats in April 2005. Uncoated pins and pins coated with several tool coatings were tested. Based on CTC data, three coatings were selected that span the baseline friction coefficient in both the dry and wet condition.

Foil Feeder - Feeds foil stock into the fin folding process. The purpose of the feeder subsystem is to position the foil within the fin folder for the start of the folding process. The team felt that feeder variability could add to the overall process variability. A specific concern was that there might be slippage between the feeder and the foil.

J.H, Benedict conducted the feeder variability test using a Model 900 fin folder without folding blades. Coiled Alloy 625 foil with lubricant was used as the feedstock.

The test consisted of running a length of foil through the feeder while measuring the total length fed and counting the number of feeder cycles. The test was repeated several times, then the median feed length, and standard deviation was calculated.

The feeder was highly repeatable (low standard deviation) and no evidence of slippage was found.

Folding Process - This is the heart of the system. It is located inside the Fin Folder (Fig. 4.4.51) where blades are sequenced to fold the foil and produce primary sheet. The bulk of the 
analysis focused on this process investigating machine speed, ram pressure, and the thickness, spacing, and coating of the blades. Computer simulation and ram pressure versus machine speed tests were completed before testing the complete system.

Development of the Altair Engineering computer model was completed in August 2004 and after final data review; the computer model design of experiments was started. The eighteen runs for the design of experiment (an $\mathrm{L}_{9}$ matrix with two compounded noise factors) were completed in November 2004. Data analysis revealed that for some parameters, optimization of the setting for one desired output conflicted with the optimized setting for another. Two subsequent $\mathrm{L}_{4}$ matrixes were designed and run to help resolve these conflicts. Results from all the runs were analyzed and used to develop the designed experiment that was to be run at J.H. Benedict (JHB) on the fin-folding machine.

JHB conducted a series of tests where machine speed and ram pressure were varied as ram displacement was recorded. LVDT-type sensors were installed on upper and lower rams to provide ram position during the cycle. A region of speeds and pressures where the ram stroked the full distance without instability was mapped. The region of stable, full strokes was at higher speeds and lower pressures than used in production, which led to the hope that the process could achieve higher productivity with lower stresses leading to longer machine life.

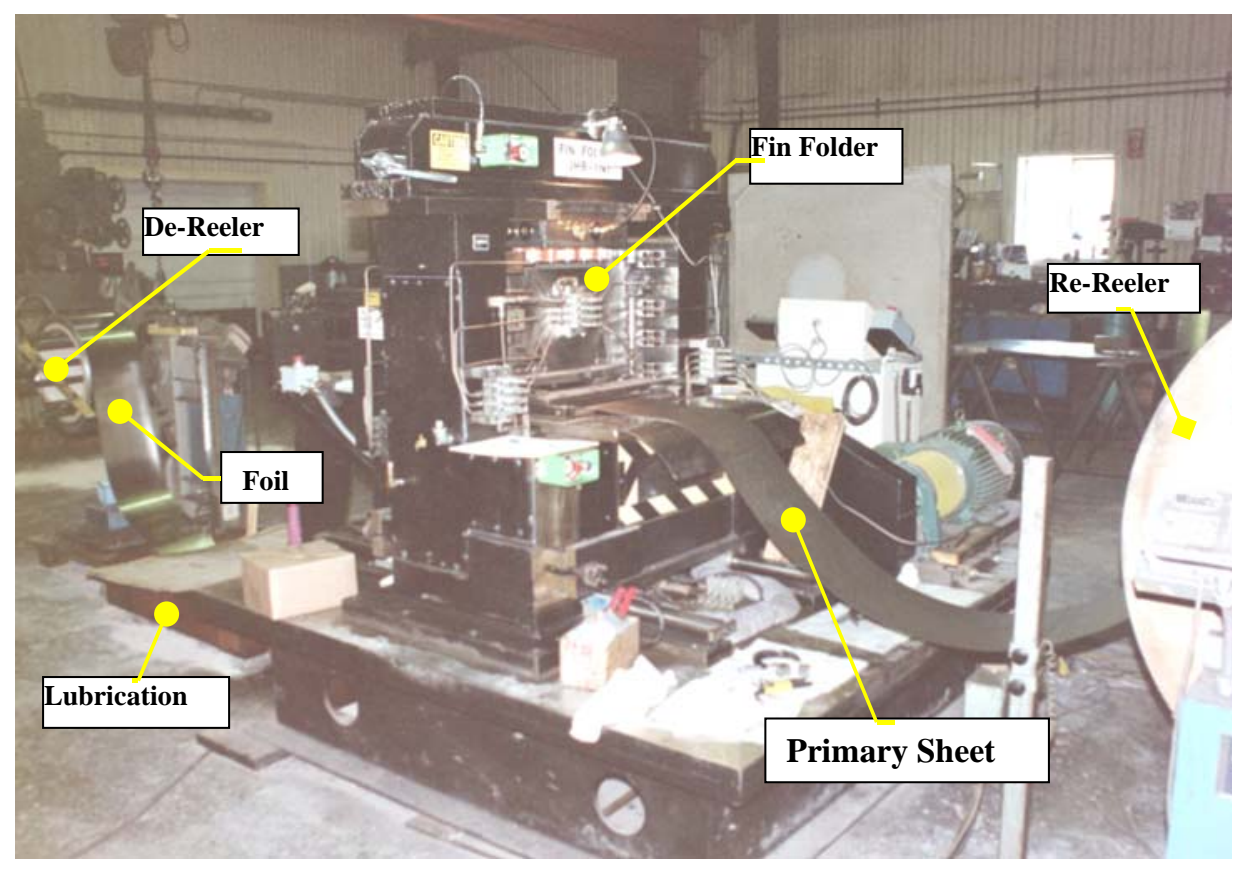

Figure 4.4.5-1. Fin Folder, Model 900 at JH Benedict

Measurement System - Measures and records various primary sheet dimensions for use in statistical process control. It uses an optical scanner and does not physically contact the primary sheet. This subsystem was analyzed and determined not to be a factor in primary sheet variability.

Re-Reeler - Takes up and stores folded primary sheet on a spool. This subsystem was analyzed and determined not to be a factor in primary sheet variability. 


\section{Analysis of Complete System}

Coated blades for the fin-folding machine at JHB were ordered in February 2005. Delivery was delayed by shop capacity constraints, but the two coated- and one uncoated-blade sets for the first designed experiment was completed in late May 2005. The first set of runs started on June 6, 2005 and was designed to determine if foil could be folded dry or if water was needed as a lubricant. Although data from previous subsystem experiments indicated that there was an excellent probability that fin folding could be accomplished while running dry or with water, only one sample was completed using water and none was completed while running dry. Additionally, the variety of settings planned would only run at low speed and high pressure. Because of this, the final design of experiments was broken down into one DoE that would optimize the internal settings of blade coating, thickness and spacing and one that would optimize the external settings of speed, lubricant concentration and ram pressure.

Data from the Taguchi $\mathrm{L}_{18}$ designed experiment was analyzed, looking for parameter settings that optimize each output. Settings that optimized some outputs degraded others, as was found in the computer model. Many approaches to multiple quality characteristics are documented. The one we followed used a Desirability Function to normalize and weigh the output values toward the desired value. The idea was to slightly compromise individual optimum settings in order to optimize the overall process. Use of this method yielded optimized settings that were predicted to increase the signal to noise ratio by $12.3 \mathrm{db}$ over the baseline. One modification was made in an attempt to increase the median value of gas/air area ratio, which has historically been in the low to below-low range of the drawing requirement. The team felt that the selected settings would run well based on the $\mathrm{L}_{18}$ experience.

Only eight of the eighteen experimental runs produced complete samples even though the setup was not substantially different from runs completed in the last DoE. This indicated that unaccounted noise was present. Investigation revealed that cam bearings were worn, but within tolerance and there was some galling on wear pads between blades. The bearings were replaced and the wear pad dressed.

A second look at the $\mathrm{L}_{18}$ data averaged the $\mathrm{S} / \mathrm{N}$ ratios for each run that used a particular parameter. For instance, the average $\mathrm{S} / \mathrm{N}$ for all runs that used TiAlN coating was calculated. The parameter having the highest average $\mathrm{S} / \mathrm{N}$ was then selected. The "paper champion" (PC) selected by this method was predicted to have a $\mathrm{S} / \mathrm{N}$ of $37.5 \mathrm{db}$. This was about $1.0 \mathrm{db}$ higher than the PC selected by the DF method and $13.4 \mathrm{db}$ higher than for the baseline configuration. This new PC was used in a second $\mathrm{L}_{9}$ DoE that was developed to test the external control factors. These included the lubrication concentration, machine speed, and blade ram pressures. The internal parameters were setup in accordance with the modified $\mathrm{L}_{18}$ results just described. This second $\mathrm{L}_{9}$ produced seven samples out of the eighteen runs. However, the CrN-coated blade confirmation and baseline runs completed indicated that the repairs to the machine accounted for some of the unaccounted noise.

Analyzed data from the $\mathrm{L}_{18}$ and both $\mathrm{L}_{9}$ experiments were used to develop the overall optimum parameters for the fin-folding process. These settings were tested in the fin folder following its move to Solar's recuperator factory in Tijuana, BC, Mexico in December 2005. Samples were taken from confirmation runs conducted on December 7, 2005 and analyzed in January 2006. The confirmation runs produced a signal to noise ratio of $25.75 \mathrm{db}$, which was $11.75 \mathrm{db}$ less than predicted and $10.36 \mathrm{db}$ less than for the baseline run just before the second L9. It was $1.65 \mathrm{db}$ greater than for the original baseline run before the $\mathrm{L}_{18}$. This variation in baseline and 
confirmation $\mathrm{S} / \mathrm{N}$ indicated the presence of still more unidentified noise factors within the fin folding process.

\section{Production Results}

The recuperator factory in Tijuana started operation with one fin folder in August 2004 and produced the first Mercury 50 recuperator in December 2004. Since then, the factory has averaged one recuperator per month to support production of engines and packages. Improvements to the production process were made as our understanding of the fin folding process increased. Production primary sheet is meeting drawing requirements consistently. The sheet lays flat with minimum cross-sheet height variation. One notable accomplishment was that durability (before breakage of \#1 blade) of uncoated blades increased to as high as 300 hours from a baseline (TurboFab) of 50 hours - a 6X improvement. A change from CPM-9V to CPM$3 \mathrm{~V}$ blade material and increasing the 1-2 blade spacing contributed to this life extension. Unfortunately, this longer life has not been consistent, and statistically no net benefit could be claimed.

The second fin folder was put into production immediately following the confirmation runs. The TiAlN-coated blades produced primary sheet for about 57 hours before blade 1 broke and they were replaced with the DLC-coated blades. The DLC-coated blades lasted for 174 hours of production. Coating wear-through was the failure mechanism. The CrN-coated blades were tried, but did not make acceptable primary sheet. Coating durability for the DLC-coated blades met the minimum of greater than one recuperator-worth of primary sheet, but the TiAlN-coated blades did not. Further testing with coated blades is planned. After the DCL blades were pulled, they were replaced with standard uncoated production blades and production resumed. With the uncoated blades, the 1-3 blade spacing was widened to get the sheet to lay flat. Pressures are in the high range, but ram pressure has a low correlation to blade breakage.

\section{Conclusions}

The objective of this project was to improve the fabrication process so that multiple drawing requirements for primary recuperator sheet can be consistently met, scrap is eliminated, and the time needed for subsequent manufacturing steps is reduced. A secondary objective was to increase the durability of the fin-folding blades.

Both fin folders in operation in Tijuana are stable and producing primary sheet that meets requirements. While other noise factors exist, and will continue to affect fin folder variability, the main issue remaining is blade durability. The potential to increase hours on blade \#1 has been demonstrated. Substantial savings are possible if this increase can be consistently realized. It remains to be seen if the blade coating will provide a net benefit. If tougher tool materials significantly extend blade life, it will more than compensate for the added cost of stripping and recoating.

\section{Recommendations}

Design changes to the primary sheet and the fin folder were out-of-scope for this project, but in the course of learning how the process works and where noise appeared, changes that might make the process more stable were suggested. 
Design improvements for consideration are as follows:

- Change to a tougher blade material such as CPM-S7. This material is much tougher than $-9 \mathrm{~V}$, but must be coated with DLC because the wear resistance is much lower.

- Modify blade design to a continuous radius (sinusoid with an amplitude of one) flow channel centerline. This will form uniform flow channels and constant thickness blades, which will eliminate pinch points in the current design near $45^{\circ}$ on either side of the peaks and valleys on blade \#3. "A" and "B" sheets as we have currently will prevent nesting.

- Provide a shoulder on the blades for bottoming. This will better form the channel bottoms, reduce spring-back at peaks and valleys, and could relieve some of the side forces from the blades at the bottom of the stroke.

- If the durability of \#1 blades proves to not be acceptable at some point due to breakage, Design Engineering has said that using thicker \#1 blades with compensating thicker \#3 blades would be considered.

Manufacturing/Process improvements for consideration are as follows:

- Provide lubrication misters just before the folding process, to replace the lubricant bath. This will reduce lubrication usage by supplying controllable, uniform lubricant at the point of use.

Other recommendations:

- Continue to monitor the performance of recuperators made with the improved primary sheet during engine test and compare to earlier (baseline) recuperators.

\subsection{TASK 1.5 Cost EVALUATION}

Statement of work: WBS 1.5 Cost Evaluation - An economic study will be performed that will define the major cost drivers of the Solar PSRs for microturbines. Major cost factors are cost of alloy folds, cost of welding of the cores, cost of ducting and tubing, as well as the level of automation, which critically affects all cost parameters. The MT-OEMs and alloy manufacturer inputs will be sought for this study. The baseline cost of the existing microturbine PSRs will become the platform, which will be used to define acceptable changes in cost for the PSRs to be developed under the program. Areas of potential cost reduction will be identified.

A cost evaluation was conducted for recuperators to be configured in advanced microturbine systems. The following conclusions were reached based on performance and cost data available from Solar's recuperator experience and from the microturbine OEMs.

1. Current microturbines are priced from $\$ 600-\$ 900$ per $\mathrm{kW}$. To become competitive with reciprocating engines, the price target for the OEMs for their microturbines should be about $\$ 350 / \mathrm{kW}$. To achieve this price target and maintain assumed industry-standard margin, production cost of the microturbine, exclusive of the recuperator, should not exceed $\$ 250 / \mathrm{kW}$. Most OEMs allot equal costs for the three major elements of the microturbine system: (1) turbine, (2) recuperator, and (3) package with control system and ancillaries. Based on the rough cost equality of each of the three major systems, the overall recuperator cost should be targeted at about $\$ 75 / \mathrm{kW}$. The recuperator manufacturer must then produce the recuperator for about $\$ 50 / \mathrm{kW}$, which gives a material cost target of roughly $\$ 25 / \mathrm{kW}$. 
2. The target material cost of $\$ 25 / \mathrm{kW}$ translates into a material cost per pound of $\$ 5$ or less. The currently widely used 347 SS meets this cost target. Candidate superalloy materials such as Alloy 625 and Haynes 230, which have commercial costs in the-\$13-24/lbm range, far exceed the cost target. A novel and promising Advanced Austenitic (AA) alloy has an initial cost of about $\$ 7 / \mathrm{lbm}$, close to the material cost target of $\$ 5 / \mathrm{lbm}$. Incorporating the AA alloy into microturbine recuperators will contribute to achieving target pricing of $<\$ 500 / \mathrm{kW}$ installed, electricity cost of $\$ 0.03-0.04 / \mathrm{kWh}$ and maintenance cost between $\$ 0.005-0.010$.

3. The Advanced Austenitic alloy has excellent oxidation properties, similar to those of Alloy 625 , and substantially superior to those of $347 \mathrm{SS}$ in simulated recuperator testing. Its creep resistance is also vastly superior to that of $347 \mathrm{SS}$, but still somewhat less than that of Alloy 625. Based on property data collected to-date the Advanced Austenitic alloy will be a costeffective recuperator material for advanced microturbine systems. This material has recently become available to the microturbine OEMs for incorporation into their recuperator designs.

The completed report on this task was uploaded to the DOE website on May 10, 2004.

\subsection{TASK 1.6 RECUPERATOR ENDURANCE TEST}

Statement of work: WBS 1.6 Recuperator Endurance Testing - While laboratory mechanical/creep, oxidation resistance, and foldability/weldability tests on laboratory specimens and subscale cores can provide valuable information on the potential of an alloy or modified alloy for the microturbine recuperators, actual operating experience with a recuperator configured for an engine will be invaluable. The ability of the selected materials to respond to the temperature and pressure regimen in the recuperator, and perform in the engine under conditions of steady state operation, and transient operation during start ups, shut downs, and trips cannot be easily duplicated outside the engine environment. An engine endurance test for up to 2,000 hrs has therefore been incorporated in the concept development task. This subtask has been scheduled to precede the final PSR detailed design for the microturbine, to enable a comparison between the various alloys and surface modifications, and select those materials strategies that are likely to meet the requirements of the MT-OEMs.

Materials strategies investigated in subtask 1.3 will be selected for the endurance test (Milestone 1.3.6 - see Program Schedule in Technical Summary). Core sections will be fabricated that will be incorporated into the hottest section of a Mercury 50 PSR in a rainbow configuration for engine testing. The recuperator core will be incorporated into a Solar Mercury 50 engine located at the Solar patio engine test site.

The modified recuperator will be evaluated for a minimum of 2,000 operating hours. The engine will be operated at its peak load condition of 9 to 1 pressure ratio and exhaust recuperator inlet of $676^{\circ} \mathrm{C}$. The engine, operating predominantly in a peaking mode, will have an average of two starts and stops per day. This high-pressure ratio and elevated recuperator hot gas inlet temperature are test conditions that are quite severe and that will enable adequate comparison between the various candidate recuperator alloys. The cost of the engine test, other than the recuperator, and the engine fuel will be part of Solar's cost share for the program.

Following the recuperator endurance test in the Mercury engine all aspects of the recuperator, including core, ducting, tubing, and welds will undergo a comprehensive inspection and visual and metallographic analysis. Evidence of oxidation will be documented photographically. 
Metallographic analysis will be conducted. Thickness, composition and morphology of oxide scales, content of carbide phases, residual $\mathrm{Cr}$ and $\mathrm{Ni}$ at the surface, etc. will all be examined. Residual strength will be determined for the recuperator cores. Valuable data on fabrication cost reduction will also be extracted from the post-mortem recuperator evaluation. ORNL and Dr. Metcalfe will assist Solar with the evaluation of the recuperator.

WBS 1.6 was originally estimated for the build and test of one recuperator with a rainbow of core materials followed by the evaluation of the recuperator core. However, after testing dual alloy recuperator cores, it was seen that building cores using materials of different thermal characteristics was detrimental to durability and therefore to recuperator performance. It was decided in 2002, with DOE concurrence, to build two recuperators, one of Alloy 625 as a necessary near-term, high-performance recuperator material and one of Advanced Austenitic as a less-expensive long-term solution. Solar preceded in this direction and built recuperator serial number (RSN) 29 using Alloy 625 in 2003. RSN 29 was tested successfully in Solar's Kearny Mesa test cell 16-1 for over 1,200 hours and 1,000 thermal cycles in early 2004. RSN 29 was then installed in the San Diego VA Hospital unit and field-tested for over 11,000 hours. Field testing started in December 2004.

A trip was made on August 21, 2002 to TurboFab in Channelview, Texas. A kickoff meeting was held, which was attended by Jim Salsgiver, Jim Rakowski, Bob Betza, and Dave Shaner from Allegheny Ludlum, Bruce Harkins, Carlos Rodriguez, and Jan Illakowicz of TurboFab, and George Escola and Chuck Bucey of Solar to start the order process for recuperator material in AA and alloy 625.

Chuck Bucey and George Escola traveled to J.H. Benedict in Peoria, Illinois March 17-20, 2003 for a final review of Task 1.4 manufacturing improvement projects that were previously completed. A trip was also made to A-L plants in Connecticut and Massachusetts from April 1418,2003 to observe the advanced austenitic material in the rolling and slitting processes.

Fabrication of a recuperator using AA was stopped when the lot of foil was lost during processing at the mill. No backup material was available to mill foil before the recuperator operation at TurboFab was shutdown in order to support the refurbishment of machines and fixtures for the new Mercury 50 recuperator factory. The factory startup and production ramp-up schedule would not allow the completion of the AA recuperator during the extended contract period of performance and the plan to complete this recuperator, again with DOE concurrence, was abandoned.

To compensate for the fact that the AA recuperator could not be completed, coupons of both Alloy 625 and AA materials were installed into the inlet plenum of RSN 29 (see Fig. 4.5-1) and were exposed to turbine exhaust conditions during the field-testing. The field evaluation unit, with a target of 8,000 to 10,000 hours of operation, exceeded 10,000 hours in February 2006 and test intervals ranged from 1,870 to 11,202 hours. These were based on the maintenance intervals of the specific Mercury 50 engine. The exposure temperature was consistently measured at $1190^{\circ} \mathrm{F}$ and the flow velocity in the recuperator was near 2.0 feet/second (Table $4.5-1$ ). 


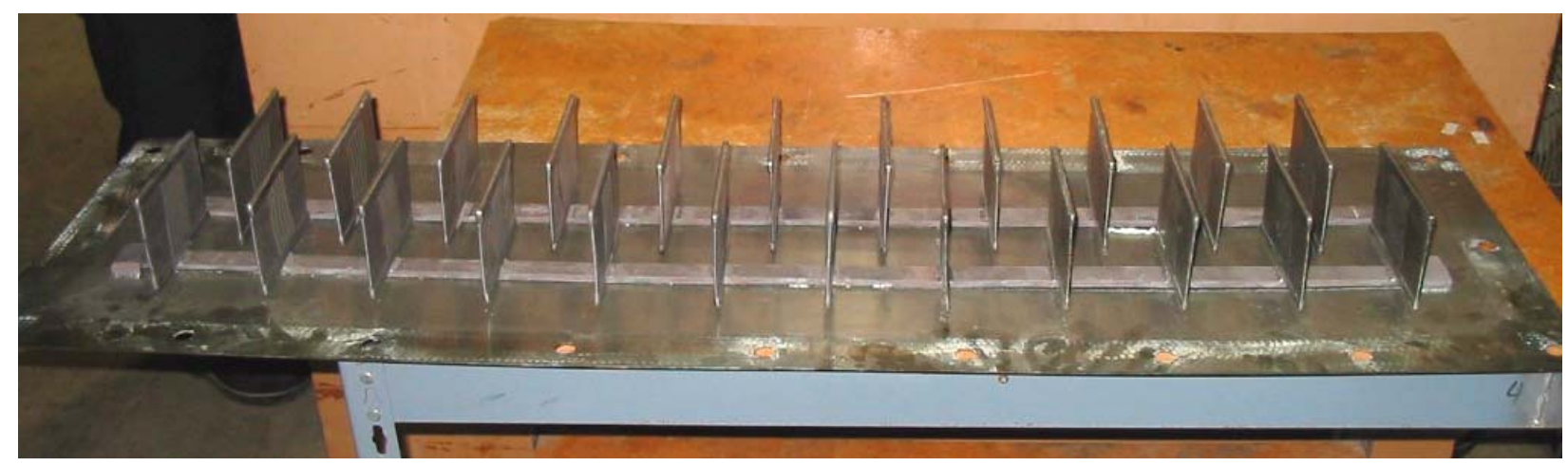

Figure 4.5-1. Alloy 625 Panel with Alloy 625 and AA Coupons that were Exposed to Mercury 50 Exhaust Gas

At each interval, test coupons were removed from the test panel and metallurgical sections were prepared so that the features of the exposed foil could be characterized. The oxide scales that had formed on the external surface of the air cells during Mercury 50 exposure were uniformly very thin, which made characterization difficult. A detailed analysis of the oxide scale composition was obtained using a scanning Auger microprobe (SAM), which was theoretically capable of measuring the surface composition to a depth resolution of a few atomic layers. SAM analysis indicated that the oxide scale on the AA was approximately one-half of a micron thick with enrichment of iron, manganese, and chromium in the oxide (Figure 4.5-2). The oxide scale on the Alloy 625 cell was also estimated to be approximately one-half of a micron thick, with significant enrichment of nickel and chromium (Figure 4.5-3). Based on the exposure testing of the air cells, it was determined that the exhaust gas produced negligible degradation during the 11,202 hour of exposure, and that it would most likely have no affect on recuperator performance. A Topical report was submitted.

Table 4.5-1. Test Cell Exposure Information

\begin{tabular}{|c|c|c|c|c|}
\hline Alloy & $\begin{array}{c}\text { Exposure } \\
\text { Interval }\end{array}$ & $\begin{array}{c}\text { Engine } \\
\text { Starts }\end{array}$ & $\begin{array}{c}\text { Gas } \\
\text { Temperature }\end{array}$ & $\begin{array}{c}\text { Approximate Gas } \\
\text { Velocity }\end{array}$ \\
\hline AL20-25- $\mathrm{Nb}^{\mathrm{TM}}$ & 1,870 hours & 121 & $1190^{\circ} \mathrm{F}$ & 2.0 feet/second \\
\hline AL20-25- $\mathrm{Nb}^{\mathrm{TM}}$ & 3,500 hours & 131 & $1190^{\circ} \mathrm{F}$ & 2.0 feet/second \\
\hline AL20-25- $\mathrm{Nb}^{\mathrm{TM}}$ & 7,650 hours & 151 & $1190^{\circ} \mathrm{F}$ & 2.0 feet/second \\
\hline AL20-25- $\mathrm{Nb}^{\mathrm{TM}}$ & 11,202 hours & 178. & $1190^{\circ} \mathrm{F}$ & 2.0 feet/second \\
\hline \hline Alloy 625 & 1,870 hours & 121 & $1190^{\circ} \mathrm{F}$ & 2.0 feet $/$ second \\
\hline Alloy 625 & 7,650 hours & 151 & $1190^{\circ} \mathrm{F}$ & 2.0 feet/second \\
\hline Alloy 625 & 11,202 hours & 178 & $1190^{\circ} \mathrm{F}$ & 2.0 feet/second \\
\hline
\end{tabular}




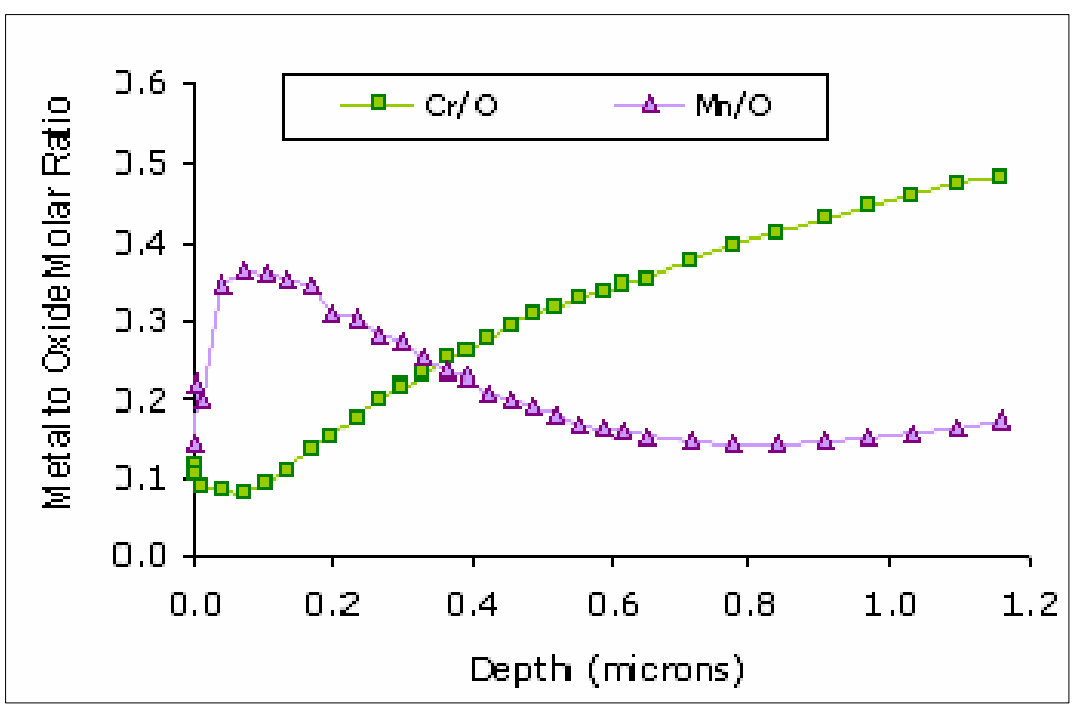

Figure 4.5-2. Auger Depth Profiles of AA Coupons Exposed for 7,650 Hours in Mercury 50 Recuperator

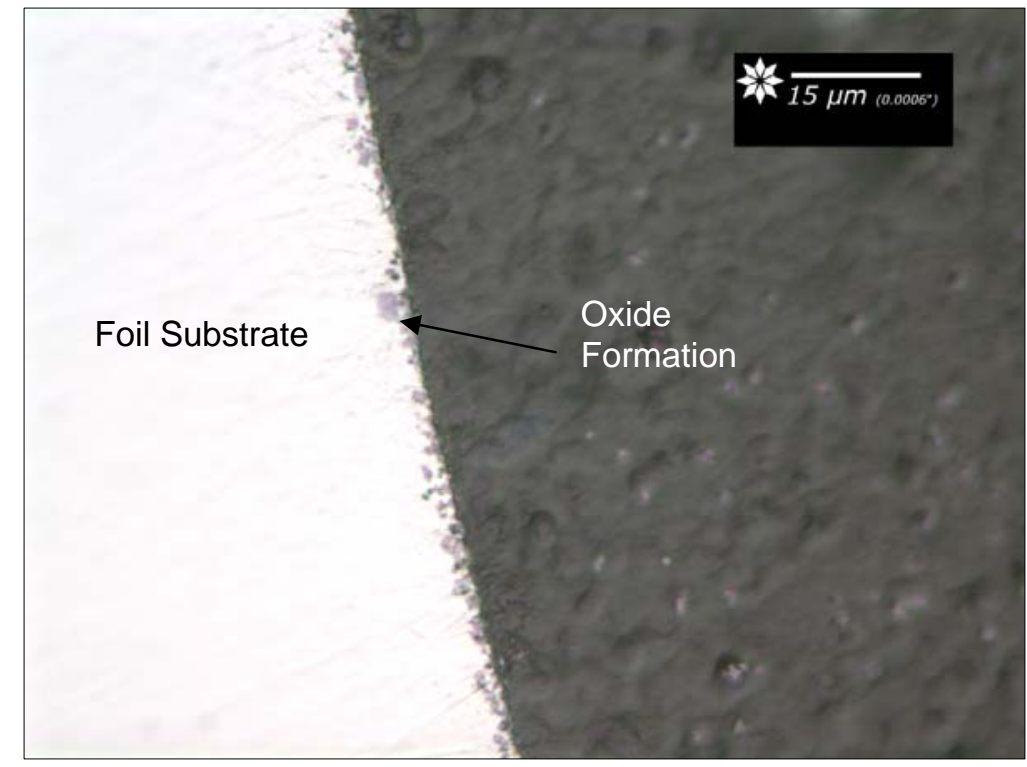

Figure 4.5-3. Metallurgical Section Through an Alloy 625 Coupon after 7,650 Hours of Exposure in a Mercury 50 Recuperator

\subsection{TASK 1.7 MICROTURBINE - PSR CONCEPT DESIGN}

Statement of Work: WBS 1.7 MT-PSR Concept Design - This subtask involves the design of uprated primary surface recuperators that meet the design, performance and cost requirements for the advanced microturbine systems of the MT-OEMs. 
No work was performed on WBS 1.7 and it was removed from the Solar program as part of the program redirection in 2002.

\subsection{TASK 1.9 CREEP CORE TESTING}

Statement of Work: WBS 1.9 Creep Core Testing - This task was added as an extension of WBS 1.3 in 2003. A key variable in the design of primary surface microturbine recuperators is the ability of the primary surface fin to resist creep deformation. As the primary surface creeps, the passages that allow exhaust gas to pass through the recuperator become restricted, resulting in higher backpressure. An increase in back pressure causes a loss in power, thermal efficiency, and operating stability of the turbine system. This mechanism of recuperator deterioration is well known but not well understood.

Simulation of the primary surface fin creep using finite element methods has been performed several times at Solar on both Alloy 625 and type 347SS. Material input data for the simulation studies was based on foil creep test data generated at Solar and Oak Ridge National Laboratory (ORNL). For reasons unknown, Solar has never been able to accurately simulate the primary surface fin creep. Typically, the simulation results will show an under-prediction of $10 X$ or more when compared to actual tested primary surface fin material. Testing will be designed to duplicate conditions from observed recuperator creep and to produce creep for desired recuperator life using type 347, Advanced Austenitic, and Alloy 625 for the creep cores to be tested.

The design and build of the creep core assemblies was completed by Solar using type 347 , Advanced Austenitic, and Alloy 625 for the creep cores. Assemblies were tested for up to 7,500 hours with some matching current operating experience and some simulating recuperator design life of 30,000 and 60,000 hours (See Table 4.7-1). ORNL tested the creep core assemblies under separate funding from DOE. Solar performed analysis of the tested cores, and updated the creep model.

A kickoff meeting was held at Solar with Edgar Lara-Curzio of ORNL on February 21, 2003. The creep core test assembly design was developed and a design review held on April 3, 2003. The design was completed (See Fig. 4.7-1) and a purchase order issued on May 28, 2003 to J.H. Benedict to fabricate the creep core test assemblies.

The folded foil and header bars were shipped from TurboFab in July 2003 to J.H. Benedict in Peoria, Illinois. One test assembly (See Fig. 4.7-2) was completed in August, inspected by Solar Engineering, and sent to ORNL. This first assembly completed system checkout testing for 500 hours in November. After review of the test data and inspection of the test fixture (See Fig. 4.73 ), a decision to go forward with the rest of the parts was made.

J.H. Benedict completed parts for the eight remaining test assemblies and these assemblies started test at ORNL in late-February 2004. 


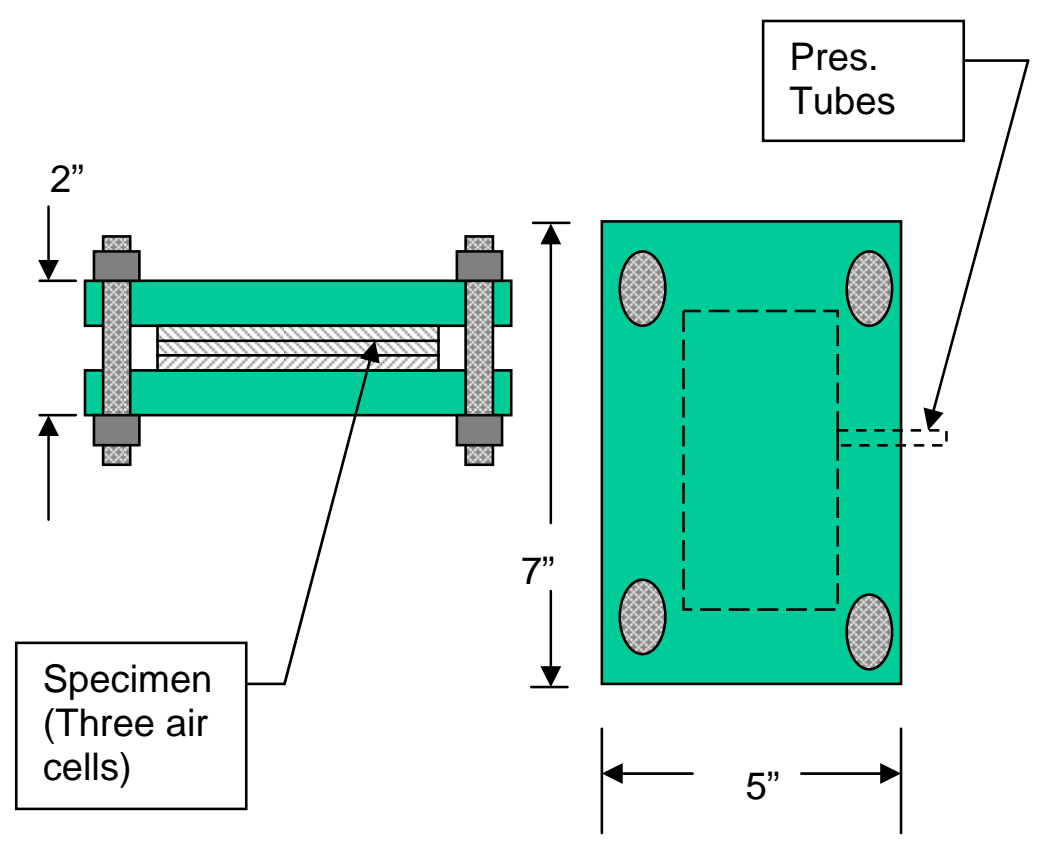

Figure 4.7-1. Creep Core Assembly Schematic

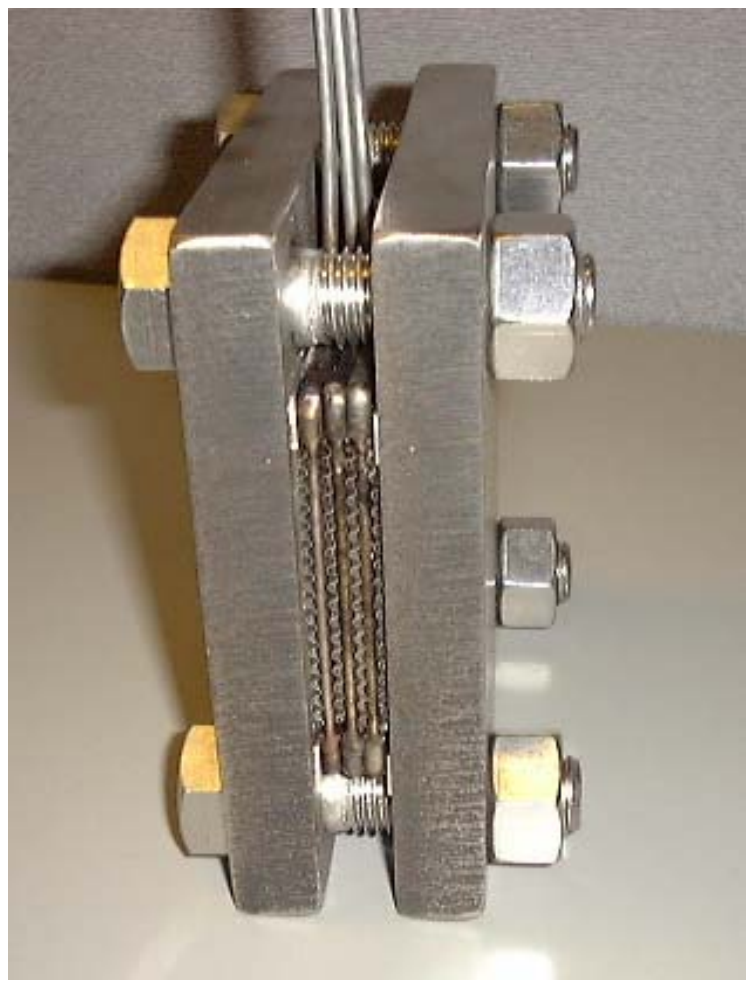

Figure 4.7-2. Creep Core Test Assembly

Nine creep cores were put into test at ORNL between March 26 and April 12, 2004. Core number nine (9) developed a leak and was removed from the furnace on April 21, 2004 after 289 
hours of testing at $660^{\circ} \mathrm{C}\left(1220^{\circ} \mathrm{F}\right)$. The goal for this core was 3,750 hours at temperature and pressure. Subsequent inspection revealed a non-repairable manufacturing defect.

Table 4.7-1. Creep Core Conditions

\begin{tabular}{|c|c|c|c|c|r|r|r|c|}
\hline \multirow{2}{*}{ Core } & \multirow{2}{*}{ Alloy } & \multicolumn{3}{|c|}{ Test Conditions } & \multicolumn{3}{|c|}{ Simulated Conditions } & \multirow{2}{*}{ Notes } \\
\cline { 3 - 8 } & Time $(\mathrm{h})$ & Metal Temp $(\mathrm{F})$ & Pressure $(\mathrm{psig})$ & Time $(\mathrm{h})$ & Exh Temp $(\mathrm{F})$ & Pressure $(\mathrm{psig})$ & \\
\hline 1 & Alloy 625 & 7500 & 1220 & 135 & 60,000 & 1200 & 135 & Standard core \\
\hline 2 & Alloy 625 & 7500 & 1220 & 135 & 60,000 & 1200 & 135 & Standard core \\
\hline 3 & Alloy 625 & 7500 & 1220 & 135 & 60,000 & 1200 & 135 & Standard core \\
\hline 4 & 347 SS & 3000 & 1190 & 120 & 3,000 & 1215 & 120 & Control case \\
\hline 5 & Adv Aust & 7500 & 1220 & 135 & 35,000 & 1200 & 135 & Standard core \\
\hline 6 & Alloy 625 & 7500 & 1235 & 135 & 60,000 & 1215 & 135 & Mixed manifolds \\
\hline 7 & 347 SS & 7500 & 1205 & 135 & 16,000 & 1200 & 135 & Mixed manifolds \\
\hline 8 & Adv Aust & 3000 & 1190 & 120 & 3,000 & 1215 & 120 & Control case, alt material \\
\hline 9 & 347 SS & 7500 & 1220 & 135 & 23,000 & 1200 & 135 & Mixed manifolds \\
\hline
\end{tabular}

All creep cores were pulled for mid-term inspections in September 2004. Inspection was completed in October 2004 (See Fig. 4.7-3). Creep in the core that duplicated conditions seen in an actual recuperator (Core \#4) was less than measured in the actual recuperator. The extent of oxidation that was seen in the actual recuperator was not seen in the creep core and that is thought to have caused the difference. All cores were returned to ORNL for further testing following the inspection.

Testing was interrupted in February when an air compressor failed. The compressor was repaired and the test resumed in early March 2005.

Testing completed on July 1, 2005. Analysis of the creep cores was completed in September 2005 and a report was prepared. Conclusions from that report were:

1. Core \#4 was meant to simulate the creep observed in a stainless steel recuperator tested on an engine (referred to here as the demonstration recuperator), acting as a control case to determine whether the creep cores provide a good representation of foil creep in operation. Unfortunately, the large discrepancy in creep between the two (with the foil in the demonstration recuperator creeping 8-10 times more than that in the creep core) indicated that additional effects, not captured in the testing, have a significant influence on the foil creep rate of Type 347 SS in operation. This discrepancy casts doubt on the creep cores' ability to simulate operating conditions. 


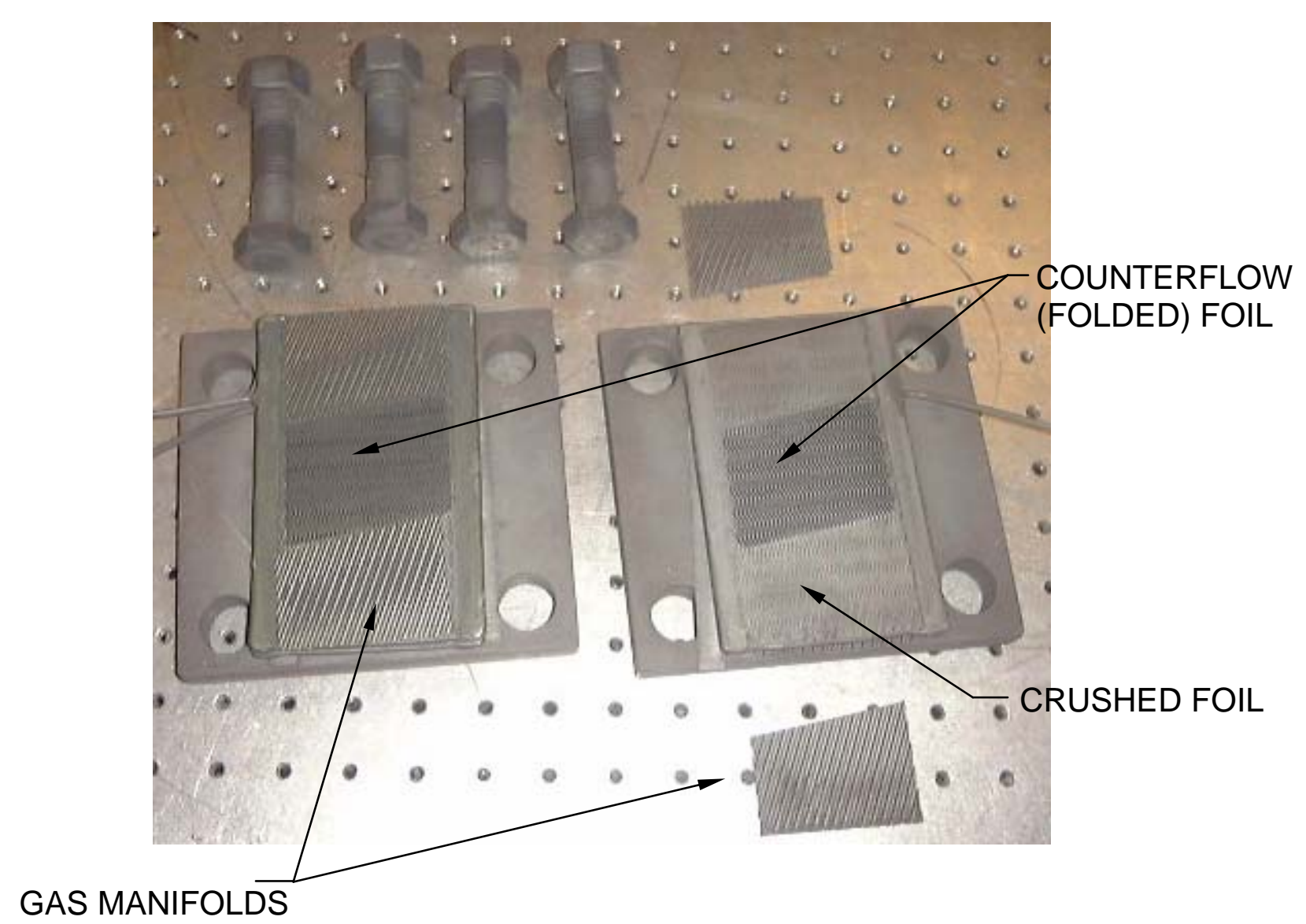

Figure 4.7-3. Creep Core Parts

2. Despite questions about correlation between the creep core tests and operating conditions, the results provide a strong indication that alloy 625 foil has sufficient creep resistance at exhaust temperatures up to $1215^{\circ} \mathrm{F}$. Even if the creep in core \#6 were multiplied by a factor of 10 (the greatest discrepancy between core $\# 4$ and the demonstration recuperator), it will be less than that observed on the demonstration recuperator, which had a turbine exhaust backpressure increase less than $2 \%$. Although some uncertainties remain about whether creep core results accurately simulate recuperator operation, completing a 7,500-hour test at elevated temperatures and a pressure several times that of a typical microturbine gives a strong indication that the alloy 625 foil has sufficient creep strength to meet service life requirements.

3. Although the advanced austenitic material (AL20-25+Nb oxidation resistance than creep resistance, it demonstrated creep strength far superior to Type 347 SS. As with the alloy 625 cores, there was very little measurable creep in the advanced austenitic cores at the completion of the tests.

4. The difference between the recuperator and the creep core results hampered the objective of developing a quantitative analytical method for predicting foil creep. The finite element analyses correlate reasonably well with the creep core results, but neither matched creep observed in sections from the demonstration recuperator. Although finite element analysis did a good job of predicting creep in the creep core, not being able to make quantitative predictions about foil behavior in operation reduces the usefulness of the analytical model. 


\subsection{TASK 2.0 - MICROTURBINE RECUPERATOR DEVELOPMENT}

Statement of Work: WBS 2.0 Detailed Microturbine Recuperator Design - The microturbine recuperator materials development and selection process, fabrication development and concept design outlined under Task 1 will form the starting point for the detailed design and evaluation of the microturbine PSR's to be conducted under Task 2. Recuperator cores and full prototype PSRs will be fabricated and tested at facilities designated by the MT-OEMs participating on the Solar team. The testing is performed either under the MT-OEMs own DOE Advanced Microturbine program, or as part of their corporate product development strategy. Regardless, the data will be analyzed and incorporated as part of the development process.

WBS 2.0 was not started and was removed from the Solar program as part of the program redirection in 2002.

\subsection{TASK 1.8 - PROGRAM MANAGEMENT}

Statement of Work: WBS 1.8 Program Management - The Task 1 program management and reporting activities are incorporated under this subtask. Solar will manage the activities of all aspects of the program team including subcontractors, subtiers, and consultants. The Solar Program Manager with the assistance of the designated Contracts Administrator and Subcontract Administrator will see to it that the deliverables of the Cooperative Agreement for the program are met according to the approved budget and schedule. The reporting requirements are outlined in Appendix A of the subject solicitation and include the milestone log, the periodic technical progress reports (format to be agreed upon by Solar and the DOE Project Officer), and the Subtask A Topical Report. Work for the Subtask A Topical Report will be performed under subtask 1.1. Technical papers will be presented at least once a year in the continental United States. Additional papers may be presented at national and international conferences as appropriate. Briefings on the program will be held: (1) within 60 days of program award, (2) 30 days before program expiration, and (3) every three months between the initial and final briefings. The final briefing will be held as part of the WBS 2 program management.

WBS 1.8 was extended as the program was extended. The scope of this task remained essentially the same, but program management charges were accumulated over seventy-two months rather than the original forty-two.

\subsection{Program Management Activities}

The program kickoff meeting was held in St Louis with the project's primary subcontractors. The overall program and near term milestones were reviewed. Financial project planning reports were forwarded to Art Few at DOE to support DOE planning.

Subsequent meetings were held with Allegheny Ludlum to finalize the statement of work and intellectual property agreement. Work on the contract started once an agreement in principle was reached. 
Discussions with contract representatives of ORNL did not produce similar common ground. An impasse developed over ORNL's "Work-for-Others Agreement," which ORNL requires, that was not acceptable to Solar. Alternatives with ORNL were explored while seeking other avenues to keep this program on track, but in the end, agreement with ORNL was not achieved. Solar determined that the commercialization of a higher temperature material, which will allow the recuperated gas turbine to produce electric power more efficiently, must take first priority and the support work that was proposed for completion by ORNL would be provided by other commercial entities. Allegheny-Ludlum submitted a quote, which was accepted to perform the materials development work that was originally quoted by ORNL.

Solar had supplied recuperators to most major microturbine original equipment manufacturers (OEMs), including Capstone, Elliott Energy Systems, Honeywell Power Systems, TURBEC, and others. Solar shipped over 2,300 recuperators for microturbine applications. However, the forecast demand for micro-turbine systems decreased dramatically and by 2001, two companies announced that they would no longer be in the microturbine business, and Solar made a strategic business decision to discontinue recuperator fabrication for the microturbine OEMs. On the other hand, the Solar Mercury ${ }^{\mathrm{TM}} 50$ neared market introduction. The Mercury 50 engine, developed under the DOE's Advanced Turbine System Program, has a high temperature recuperator as a core assembly. The experience gained with PSR recuperator material and manufacturing development for the Mercury 50 would be very valuable for the microturbine OEMs in their efforts to develop high performance recuperators for their advanced microturbines. These factors together with the funding profile for FY01 and FY02, which was less than required for the original full program, led DOE and Solar to redirect and restructure the program to better fit the available funding and program objectives.

The redirected program concentrated on the development of a new, economical recuperator material, an Advanced Austenitic Alloy that would allow operation at higher temperatures. Tasks involving direct work with microturbine companies were dropped as Solar made a business decision to license the manufacture of microturbine recuperators to microturbine OEMs. To further decrease funding requirements, some manufacturing technologies intended to reduce total recuperator cost were continued under Solar funding while others were delayed until funding became available. Laboratory tests to verify the material's capability remained part of the work scope along with the build of a full-scale, Mercury 50 recuperator for final material capability verification. Testing of the full-scale recuperator was to be performed as part of other Solar-funded programs. The build and evaluation after test of the full-scale recuperator was retained within the program scope of work. The new Advanced Austenitic Alloy was to be made available to microturbine companies for evaluation and commercial use within their microturbine recuperators.

An overview of the program was given at the Microturbine and Gas Turbine Peer Review March 12-14, 2002 in Fairfax, Virginia.

A trip to Allegheny Ludlum in Pittsburgh, Pennsylvania was made in July 2002. The Intellectual property agreement was negotiated with Tony More, Jim Salsgiver and Pat Viccaro. Program status was reviewed with Jim Salsgiver and Jim Rakowski. Several materials under development in WBS 1.3 were deselected as described above. Advanced austenitic and alloy 625 were selected for testing in full-scale recuperators. 
A program review with DOE was completed on September 24, 2002 at the Solar Turbines headquarters in San Diego, California. An Executive review was held in Washington DC on October 2, 2002.

A program review with DOE was conducted at Solar headquarters on March 5, 2003.

A review of all Solar/DOE programs, including the Microturbine Recuperator Program was conducted on September 11, 2003 in San Diego, California. Minutes with action items were written and promulgated to attendees.

A presentation on the Microturbine Recuperator program was made at the Second DOE Peer Review, December 2-4, 2003 in Washington D.C. Commercialization of the Advanced Austenitic material by Allegheny Ludlum was announced.

A review of all of Solar's DOE funded programs was conducted on March 22, 2004 in San Diego, California. Minutes with action items were published.

The Task 1.8, Cost Evaluation Topical Report was submitted on April 30, 2004.

An executive review of Solar's DOE funded programs was conducted on July 14, 2004 in Washington D.C. Minutes with action items were published to attendees.

A review of Solar's DOE funded programs was conducted on November 4, 2004 in San Diego, California. Minutes with action items were published to attendees.

A review of Solar's DOE funded programs was conducted on February 2, 2005 in San Diego, California. Minutes with action items were published to attendees.

A meeting with DOE, which included an update of the Microturbine Recuperator Program was held on May 11, 2005 in Washington D.C.

A no-cost extension to the program to September 30, 2006 was granted.

An overview of the program was given at the 2005 Distributed Energy Peer Review that was held December 13-15, 2005 in Crystal City, Virginia

A review of Solar's DOE funded programs was conducted on August 23, 2006 in Washington D.C. Minutes with action items were published.

ASME paper GT2006-90144, IMPROVEMENT OF MICROTURBINE RECUPERATORS USING TAGUCHI METHODOLOGY was presented the ASME Turbo Expo 2006 Power for Land, Sea \& Air, May 8-11, 2006 in Barcelona, Spain.

The Cooperative Research and Development of Primary Surface Recuperator for Advanced Microturbine Systems Program officially ended on September 30, 2006 and a Draft Final Report was submitted.

Table 5.1-1 lists the contract modifications over the life of the program. 
Table 5.1-1. Contract Modifications

\begin{tabular}{|c|c|c|c|c|}
\hline Mod. & Date & $\begin{array}{l}\text { Funding } \\
\text { Added }\end{array}$ & Total Funding & Comments \\
\hline Original & $9-30-00$ & $\$ 500,000$ & $\$ 500,000$ & $\begin{array}{l}42 \text { Months: } 9-30-00 \text { to } 3-31-04 \text {, } \\
\text { Maximum Funding: } \$ 4,555,859\end{array}$ \\
\hline 001 & $6-21-01$ & $\$ 518,650$ & $\$ 1,018,650$ & \\
\hline 002 & $6-14-02$ & $\$ 400,000$ & $\$ 1,418,650$ & \\
\hline 003 & $2-4-03$ & $\$ 200,000$ & $\$ 1,618,650$ & $\begin{array}{c}\text { George Escola replaced Mike Ward } \\
\text { as Program Manager }\end{array}$ \\
\hline 004 & $5-2-03$ & $\$ 450,000$ & $\$ 2,068,650$ & $\begin{array}{c}\text { Dale Dietzel replaced Steve Waslo } \\
\text { as DOE Program Officer }\end{array}$ \\
\hline 005 & $7-7-03$ & $\$ 0$ & $\$ 2,068,650$ & $\begin{array}{l}\text { Change Contract \#, Program, } \\
\text { Contracts, \& Finance Offices }\end{array}$ \\
\hline 006 & $9-30-03$ & 125,000 & $\$ 2,193,650$ & $\begin{array}{c}\text { Paul Bakke replaced Dale Dietzel as } \\
\text { DOE Program Officer }\end{array}$ \\
\hline 007 & $1-23-04$ & $\$ 310,000$ & $\$ 2,503,650$ & $\begin{array}{l}\text { Extended Period of Performance to } \\
\qquad 9-30-05\end{array}$ \\
\hline 008 & $2-18-04$ & $\$ 690,000$ & $\$ 3,193,650$ & \\
\hline 009 & $3-16-04$ & $\$ 0$ & $\$ 3,193,650$ & $\begin{array}{c}\text { Don Geiling replaced Paul Bakke as } \\
\text { DOE Program Officer, Change } \\
\text { Contract \#, Program, Contracts, \& } \\
\text { Finance Offices }\end{array}$ \\
\hline 010 & $9-22-04$ & $\$ 450,000$ & $\$ 3,643,650$ & $\begin{array}{c}\text { Doug Gyorke replaced Don Geiling } \\
\text { as DOE Program Officer }\end{array}$ \\
\hline 011 & $1-14-05$ & $\$ 200,000$ & $\$ 3,843,650$ & \\
\hline 012 & $4-4-05$ & $\$ 361,000$ & $\$ 4,204,650$ & \\
\hline 013 & $9-30-05$ & $\$ 0$ & $\$ 4,204,650$ & $\begin{array}{l}\text { Extended Period of Performance to } \\
\qquad 9-30-06\end{array}$ \\
\hline 014 & $9-30-06$ & $\$ 41,919$ & $\$ 4,246,569$ & $\begin{array}{l}\text { Extended Period of Performance to } \\
10-31-06\end{array}$ \\
\hline 015 & $1-17-07$ & $\$ 0$ & $\$ 4,246,569$ & Budget reduced to actual expended. \\
\hline
\end{tabular}


Fig. 5.1-1 Shows the funding and spending over the life of the contract.

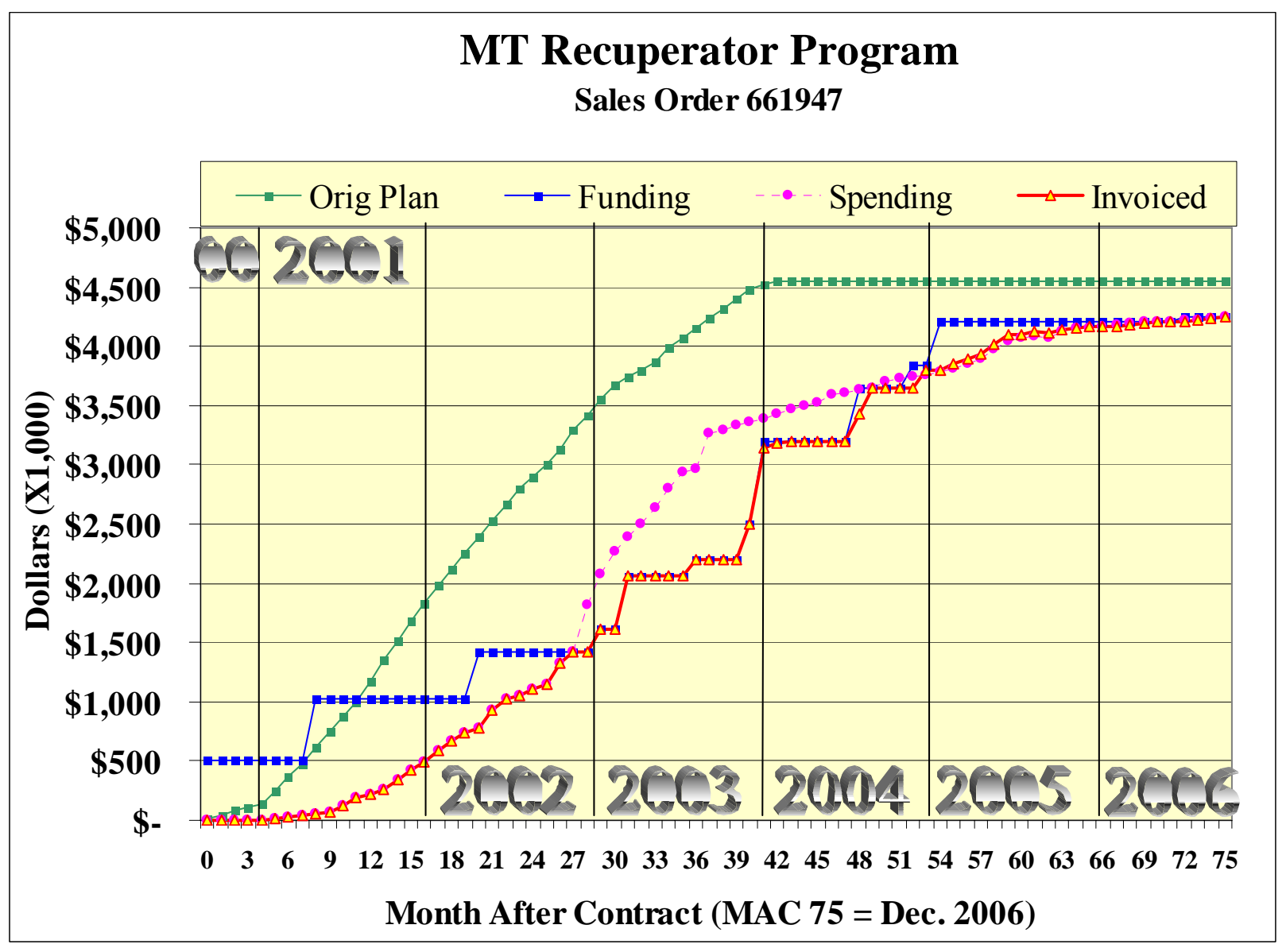

Figure 5.1-1. Funding and Spending Over the Life of the Contract

Fig. 5.1-2 shows the program schedule at completion. 


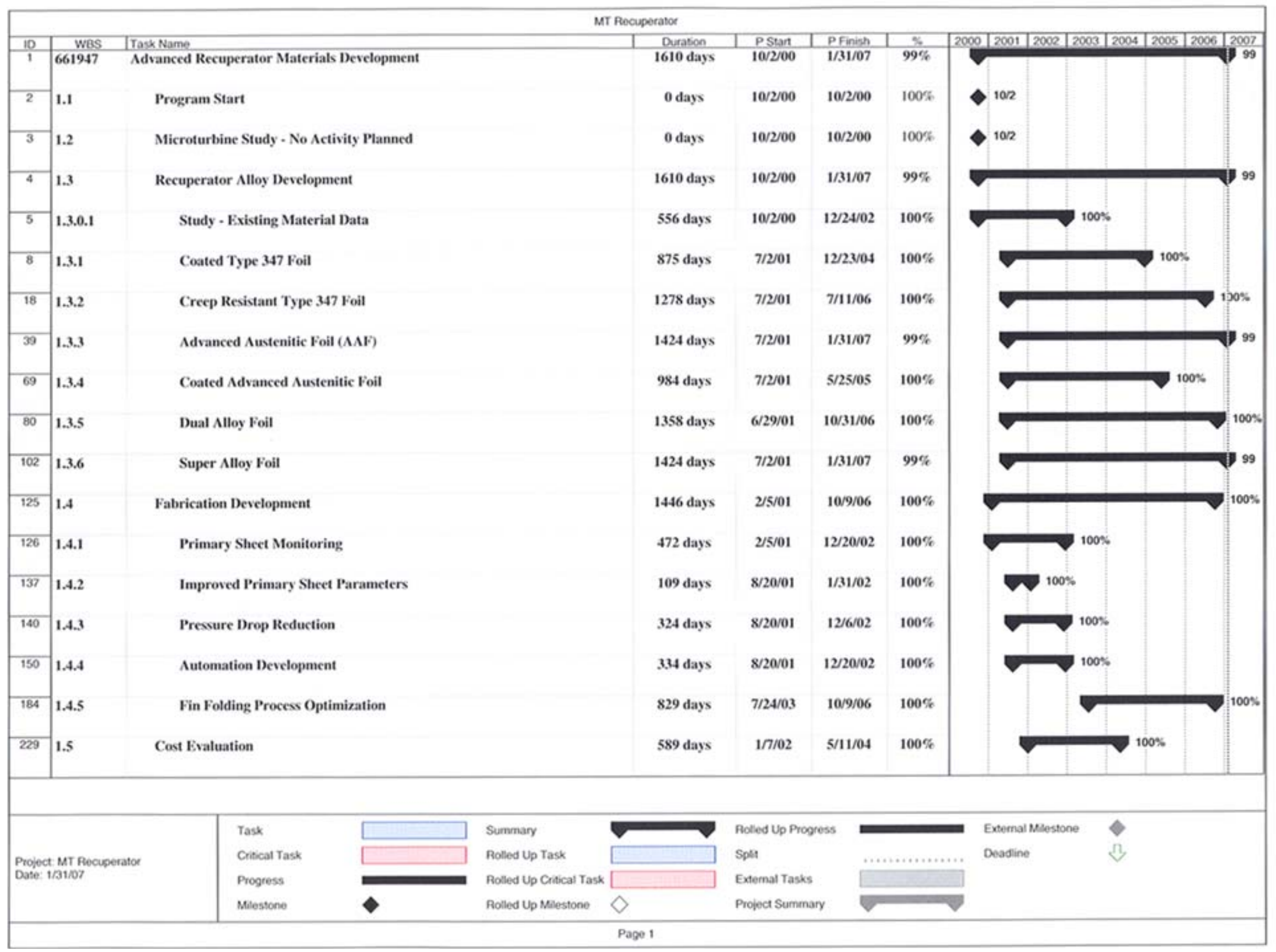

Figure 5.1.2. Program Schedule 


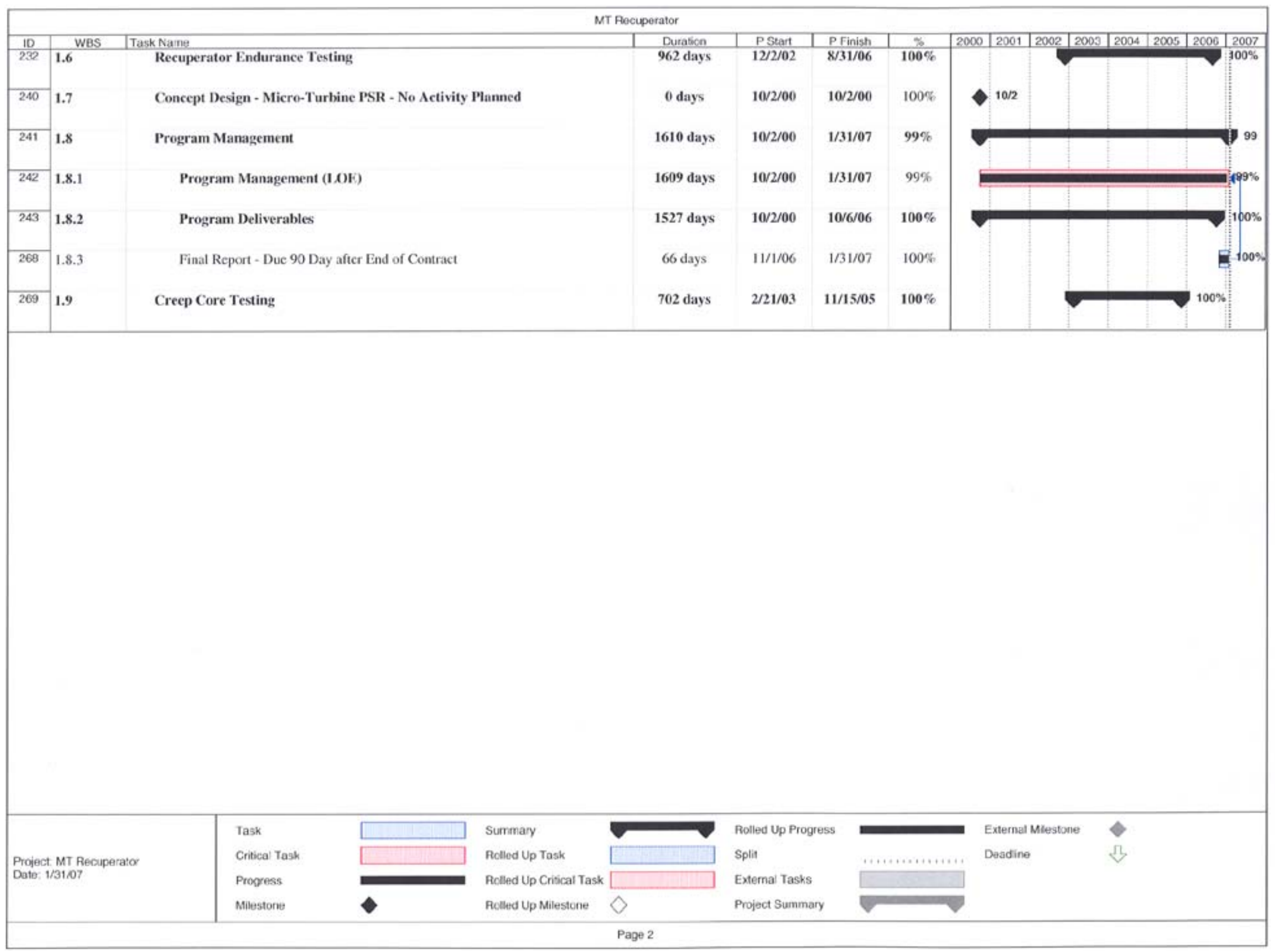

Figure 5.1.2. Program Schedule 


\subsection{BIBLIOGRAPHY}

Rakowski, J.M., "The Oxidation of Metal Alloy Foils in the Presence of Water," ASME paper GT2003-38059, Atlanta, GA, USA, June 16-19, 2003.

Rakowski, J.M, Stinner, C.P., Lipschutz, M., and Montague, J.P., "The Use and Performance of Oxidation and Creep Resistant Stainless Steel in an Exhaust Gas Primary Surface Recuperator Application,” ASME paper GT2004-53917, Vienna, Austria, June 14-17, 2004.

Taguchi, G., 2005 “Taguchi’s Quality Engineering Handbook” John Wiley \& Sons, Inc.

Roy, R. K., 2001 "Design of Experiment Using the Taguchi Approach: 16 Steps to Product and Process Improvement” John Wiley \& Sons, Inc.

Phillips, P. W. and Kim, K.-J., 1999 “Taguchi Parameter Design with Multiple Quality Characteristics" ASQ.

Escola, G.E., Bucey, C.W., Montague, P., Telfer, M.J., McClain, J., Patel, M., Miars, C., and Shockley, M., "Improvement of Microturbine Recuperators Using Taguchi Methodology," ASME paper GT2006-90144, Barcelona, Spain, May 8-11, 2006.

Rakowski, J.M, Stinner, C.P., Lipschutz, M., and Montague, J.P., "Metallic Alloys for Primary Surface Recuperators,” ASME paper GT2006-90680, Barcelona, Spain, May 8-11, 2006.

Rakowski, J.M, Stinner, C.P., Lipschutz, M., and Montague, J.P., “Alloy Testing in a Simulated Recuperator Environment, ASME paper to be presented at the ASME TURBO EXPO, Montreal, Canada, May 11-14, 2007.

Rakowski, J.M, Stinner, C.P., "Prediction of Oxidation-Limited Lifetime of Stainless Steel Foils for Primary Surface Recuperators" to be presented at NACE 2007, Nashville TN, March 11-15, 2007.

Rakowski, J.M, Stinner, C.P., "Prediction of Oxidation-Limited Lifetime of Thin Austenitic Stainless Steel Foils in Air Containing Water Vapor" presented at MS\&T 2006, Cincinnati, OH, October 15-19, 2006.

Stinner, C. P., Rakowski, J. M., Maziasz, P., Montague, J. P. "An Improved Creep and Oxidation Resistant Stainless Steel for Heat Exchanger and Recuperator Applications" Presented at ASM Materials Solutions Columbus, OH October 18-21, 2004.

Rakowski, J.M, Stinner, C.P., Lipschutz, M., and Montague, J.P., The Use and Performance of Wrought 625 Alloy in Primary Surface Recuperators for Gas Turbine Engines Superalloys 718 and Derivatives, October 2-5, 2005.

Rakowski, J.M, Stinner, C.P., Lipschutz, M., and Montague, J.P., The Use and Performance of Wrought 625 Alloy in Primary Surface Recuperators for Gas Turbine Engines CORROSION/2005 April 3-7, 2005 Houston TX.

Rakowski, J.M, Stinner, The Effect of Water Vapor on the Oxidation of Nickel-Base Superalloy Thin Foils, ASM Materials Solutions Columbus, OH October 18-21, 2004. 